Mauro Meirelles de Oliveira Santos

\title{
Geração de Biogás em Aterros Sanitários: \\ Uma análise sobre os modelos de previsão aplicados a projetos do Mecanismo de Desenvolvimento Limpo
}

Dissertação apresentada como requisito parcial para obtenção do título de Mestre em Engenharia Urbana e Ambiental (opção profissional) pelo Programa de Pós-Graduação em Engenharia Urbana e Ambiental da PUC-Rio.

Orientador: Prof. Celso Romanel Co-orientadora: Profa. Ana Ghislane Pereira van Elk

Rio de Janeiro

Dezembro de 2014 
Mauro Meirelles de Oliveira Santos

\title{
Geração de Biogás em Aterros Sanitários: Uma análise sobre os modelos de previsão aplicados a projetos do Mecanismo de Desenvolvimento Limpo
}

\begin{abstract}
Dissertação apresentada como requisito parcial para obtenção do título de Mestre em Engenharia Urbana e Ambiental (opção profissional) pelo Programa de Pós-Graduação em Engenharia Urbana e Ambiental da PUC-Rio. Aprovada pela Comissão Examinadora abaixo assinada.
\end{abstract}

Prof. Celso Romanel

Presidente / Orientador Departamento de Engenharia Civil - PUC-Rio

Profa. Ana Ghislane Henriques Pereira van Elk Co-orientadora

PNUD

Prof. Geraldo Antônio Reichert

UCS

Prof. Claudio Fernando Mahler

UFRJ

Prof. José Eugenio Leal Coordenador Setorial de Pós-Graduação do Centro Técnico Científico - PUC-Rio

Rio de Janeiro, 19 de dezembro de 2014. 
Todos os direitos reservados. É proibida a reprodução total ou parcial do trabalho sem autorização da universidade, do autor e do orientador.

\section{Mauro Meirelles de Oliveira Santos}

Graduou-se em Engenharia Eletrônica no Instituto Militar de Engenharia, no Rio de Janeiro em 1977, obteve títulos de pósgraduação em Administração da Produção e Relações Industriais na Fundação Getúlio Vargas de São Paulo em 1984, e em Gestão Ambiental na Universidade Federal do Rio de Janeiro em 2005. Há 14 anos trabalha junto ao Ministério da Ciência, Tecnologia e Inovação para o inventário nacional de gases de efeito estufa e na análise de projetos MDL. É revisor de inventários dos países industrializados, junto à UNFCCC. Por sua participação nas publicações do IPCC, co-recebedor do Prêmio Nobel da Paz de 2007.

Ficha Catalográfica

Santos, Mauro Meirelles de Oliveira.

Geração de biogás em aterros sanitários: uma análise sobre os modelos de previsão aplicados a projetos do mecanismo de desenvolvimento limpo / Mauro Meirelles de Oliveira Santos; orientadora: Ana Ghislane Pereira van Elk, Celso Romanel. - 2014.

114 f. il. (color.); $30 \mathrm{~cm}$

Dissertação (mestrado) - Pontifícia Universidade Católica do Rio de Janeiro, Departamento de Engenharia Civil, 2014.

Inclui bibliografia

1. Engenharia civil - Teses. 2. Aterros sanitários. 3. Geração de biogás. 4. Modelos. 5. MDL. 6. Mecanismo de desenvolvimento limpo. I. Van Elk, Ana Ghislane Pereira. II. Romanel, Celso. III. Pontifícia Universidade Católica do Rio de Janeiro. Departamento de Engenharia Civil. IV. Título.

CDD: 624 


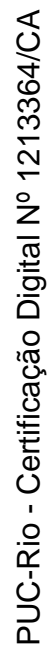

A meus pais, Vespasiano (in memoriam) e Hebe. 


\section{Agradecimentos}

Aos meus orientadores, Professora Ana Ghislane Pereira van Elk e Professor Celso Romanel, pelo estímulo para a realização deste trabalho.

À minha mãe, que muito me apoiou para a concretização deste curso.

À minha irmã e meus irmãos, pelo incentivo desde as primeiras horas.

Aos meus colegas da PUC-Rio.

Aos professores que participaram da Comissão examinadora.

A meus filhos, pela compreensão pelas horas suprimidas do seu convívio.

À minha esposa Analu que, além de me dar todo o incentivo para meus estudos e suporte em casa nos momentos de ausência, suportou meus momentos de desânimo e mau humor. 


\section{Resumo}

Santos, Mauro Meirelles de Oliveira; Romanel, Celso. Geração de Biogás em Aterros Sanitários: Uma análise sobre os modelos de previsão aplicados a projetos do Mecanismo de Desenvolvimento Limpo. Rio de Janeiro, 2014. 114p. Dissertação de Mestrado - Departamento de Engenharia Civil, Pontifícia Universidade Católica do Rio de Janeiro.

O propósito do trabalho é avaliar os modelos matemáticos utilizados para a previsão da geração de biogás pelos aterros sanitários brasileiros e comparar as previsões com os resultados monitorados ao longo dos anos de operação. Cerca da metade do volume desse biogás é metano, sendo essa a sua parte mais significativa; primeiro, porque é um gás de efeito estufa; segundo, porque a sua queima, além de desejável, pode gerar energia - e renovável. Por isso, projetos de aterros que queimam metano podem receber incentivos financeiros - os créditos de carbono através do Mecanismo de Desenvolvimento Limpo (MDL) do Protocolo de Quioto. Os aterros sanitários estudados são todos projetos MDL, para os quais existe obrigatoriamente um prévio documento de concepção, com as previsões de resultados, bem como documentos periódicos posteriores comprovando as metas alcançadas, todos publicados na internet. Pelo método de trabalho, explicitam-se a previsão de geração do metano - contidas no documento de concepção de projeto - e a quantidade captada - contida nos relatórios de monitoramento. Os modelos, parâmetros, resultados e eficiências são apresentados, bem como comparações entre diferentes aterros e modelos. Ao final do trabalho, responde-se a questão: as eventuais discrepâncias entre a previsão de geração e a captação efetiva de biogás dos aterros sanitários operados sob o MDL podem ser explicadas pelo uso inadequado dos modelos de previsão?

\section{Palavras-chave}

Aterros sanitários; geração de biogás; modelos; MDL; Mecanismo de Desenvolvimento Limpo. 


\section{Expanded Abstract}

Santos, Mauro Meirelles de Oliveira; Romanel, Celso (Advisor). Biogas

Generation In Landfills: An analysis on the forecast models used by projects under the Clean Development Mechanism. Rio de Janeiro, 2014. 114p. Master degree thesis - Departamento de Engenharia Civil - Pontifícia Universidade Católica do Rio de Janeiro.

\section{INTRODUCTION}

Solid waste disposal sites (SWDS) - especially landfills - are a significant source of methane. Although having the potential to be captured and used as a fuel, most of the methane formed in SWDS is emitted to the atmosphere. After the United Nations Framework Convention on Climate Change entered into force in 1994 with the final goal of preventing climatic changes, all the countries that have ratified it were asked to estimate and report their greenhouse gas emissions, including methane. In order to support countries in this task, the Intergovernmental Panel on Climate Change (IPCC) has published three sets of guidelines for national inventories, including sets of equations for calculating the quantity of methane formed as biodegradable waste decays. In addition, the Kyoto Protocol has created the Clean Development Mechanism (CDM) to assist the developed countries to offset their own greenhouse gas emissions by assisting other countries to achieve sustainable development and to reduce their emissions. Based on IPCC's methodologies, the CDM has issued a tool to help developers estimate reductions in methane emissions as a result of their project activities. Unfortunately, the four methodologies for calculating methane formation in landfills that are used worldwide - three from IPCC and one from CDM - yield different results, although they are all based on equations to simulate first order decay of biodegradable waste. Furthermore, differences in results from the use of the different models are not clearly presented, and there is not a clear understanding on how they should be used. The incorrect application of the methodologies can be seen in national inventories and in CDM projects activities.

The purpose of this thesis is to assess the mathematical models used to predict the generation of biogas by landfills in Brazil and to compare the forecasts with the monitored results over the years of operation. According to Scharff and Jacobs (2006), the emission from a landfill has a high temporal and spatial variability and the authors assert that this is a complicated area of study. Approximately half the volume of this biogas is methane, which is its most significant part; firstly, because it is a greenhouse gas; and secondly, because its burning, as well as being desirable, can generate energy - of the renewable type. For this reason, landfill projects that burn methane are able to receive financial incentives - the carbon credits - through the CDM. Since 2005, when the Kyoto Protocol entered into force and launched the CDM, solid waste disposal sites are seen differently in Brazil.

The landfills studied here are CDM projects that had their potential for biogas 
evaluated at their inception and which later on had their generation models and their parameters re-evaluated. These projects have undergone a renewal of their first 7year crediting period, within the CDM procedures, when it was necessary to update the baseline and monitoring methodology.

In order to have an ex-ante estimation of the methane generation in CDM landfill projects, it is necessary to follow the methodologies approved by the CDM Executive Board. These methodologies are based on the procedures used for national greenhouse gas inventories of the IPCC, which in turn assesses the scientific knowledge around the world on climate change and greenhouse gases.

There are three editions of IPCC guidelines (1997, 2000 and 2006), other than several versions for the ones issued by the CDM Executive Board. This thesis shows the differences among the models contained in these methodologies, besides the different interpretations and different ways to apply the methodologies in the analyzed projects. Two more models were added to the analysis: those referred to in World Bank (2004) - the so-called Scholl-Canyon model and the U.S. EPA's LFG Emissions Model (LandGEM).

All CDM projects are required to have a prior design document as well as verified monitoring reports, which demonstrate the emission reductions, all documents published on the Internet. The method of work used in this study was to highlight for each project the generation forecast and the amount of methane captured during several years of operation, with the knowledge that these figures are not a simple translation of carbon credits. CDM procedures require some baseline and leakage discounts and allow more credits whenever electricity is generated from the biogas, and these facts have to be understood and taken into account. Models, parameters, results and efficiencies are then presented and compared.

Based on the analyses of the models, the authors also indicate the need for a correction in the tool to calculate emissions from landfills as adopted by the CDM Executive Board.

This thesis also shows how the experience of the first 7-year crediting period of each project was used in its second period, and makes a critical analysis of the suitability of the use of these prediction models, as well as a confrontation with other studied models, where the data was adequate.

This study has the ultimate intent to contribute to enterprises that are designed to improve sanitary conditions and to mitigate climate change using methane as a valuable clean energy source.

\section{THE MODELS}

In Brazil, the need for quantification of the methane generated from solid waste disposal sites arose only after the establishment of UNFCCC, more specifically after its Kyoto Protocol. Therefore, under this context, projects in Brazil collecting methane just for flaring or for energy purposes start using the IPCC guidelines for national GHG inventories, which include models for emissions from solid waste disposal sites. Mathematical models for estimation of these emissions are proposed in its three publications: "Revised 1996 IPCC Guidelines for National Greenhouse Gas Inventories" (IPCC, 1997), "Good Practice Guidance and Uncertainty Management in National Greenhouse Gas Inventories" (IPCC, 2000), and "2006 
IPCC Guidelines for National Greenhouse Gas Inventories" (IPCC, 2006). Each publication has slightly different ways to translate the mathematical model called the First Order Decay - FOD, which is suitable for a continuous time variable, into a discrete timestep calculation. The IPCC FOD models are also the roots for the methodology used to estimate the baseline emissions in a project activity on destruction of methane from landfills under the CDM.

According to Van Elk (2007), biodegradable waste disposed in a landfill undergoes a complex set of microbially-mediated decay processes. After a short aerobic degradation phase, which may last for some weeks, the oxygen in the waste is used up, leading to the growth of methanogenic bacteria, which produce methane. The degradable organic matter - or degradable organic carbon - is consumed slowly by the bacteria throughout a few decades, at negative exponential rates, reflecting in the process by which methane is generated and eventually emitted to the atmosphere.

There are two basic parameters for the FOD model: the decay (or reaction) constant $k$ and the methane generation potential, $L_{0}$. The constant $k$ is based on the half-life of degradable carbon in the landfill, according to the following equation:

$$
\mathrm{k}=\ln (\mathrm{A} 2) / \mathrm{t}_{1 / 2} \quad\left(\text { year }^{-1}\right)
$$

where $t_{1} / 2$ is the half-life (year) of the degradable carbon from waste.

The methane generation potential $L_{0}\left[\mathrm{t} \mathrm{CH}_{4} / \mathrm{t}\right.$ waste or $\mathrm{m}^{3} \mathrm{CH}_{4} / \mathrm{t}$ waste] represents the theoretical maximum amount of methane generated by a quantity of waste over infinite time. This amount is maximum in a landfill situation, where the waste is in anaerobic condition, and will be released after many years of decay. In order for $L_{0}$ to represent the maximum emission per tonne of waste with mass $M$, the equation for the methane generation as function of time $t$ should be of the following type, under ideal anaerobic condition:

$$
\mathrm{Q}(\mathrm{t})=\mathrm{k} \times \mathrm{M} \times \mathrm{L}_{0} \times \mathrm{e}^{-\mathrm{kt}}
$$

In this case, the total generated amount will be the solution of the definite integral evaluated from $t=0$ to $t \rightarrow \infty$ :

$$
\int_{0}^{\infty} Q(t) d t=\left[-M \times L_{0} \times e^{-\mathrm{k} . \infty}+C\right]-\left[-M \times L_{0} \times e^{-\mathrm{k} .0}+C\right]=M \times L_{0}
$$

If a model using the FOD approach can be reduced to the type of eq. (A2), then the constant $L_{0}$ has its real meaning, which is of being the methane generation potential as defined above. It is also a boundary condition: if the result of the definite integral were like $M \times \alpha \times L_{0}$, $\alpha$ being a fixed number, the real methane generation potential would be $L_{0}{ }^{\prime}=\alpha \times L_{0}$. Therefore, it is a way to of verifying that a given equation is correct, at least in terms of total emissions.

The FOD model will now be presented accordingly to each of those focused publications, in the order they were released. Furthermore, the models indicated in World Bank (2004) will be included in this analysis. The methane recovered and the possible fraction of methane oxidized in the landfill cover layer will not be included here, as both of which can be added in due course, with the use of measurements or default values.

\subsection{Revised 1996 IPCC Guidelines for National Greenhouse Gas Inventories}


(IPCC, 1997)

IPCC (1997) provides an equation ${ }^{1}$ for estimating methane generation from waste landfilled in a single year:

$$
\mathrm{Q}_{\mathrm{T}, \mathrm{x}}=\mathrm{k} \times \mathrm{R}_{\mathrm{x}} \times \mathrm{L}_{0} \times \mathrm{e}^{-\mathrm{k}(\mathrm{T}-\mathrm{x})}
$$

where:

$\mathrm{Q}_{\mathrm{T}, \mathrm{x}}=$ the amount of methane generated in the current year $T$ by the waste $R_{x}$ $\mathrm{x}=$ the year of waste input

$\mathrm{R}_{\mathrm{x}}=$ the amount of waste disposed in the year $x(\mathrm{Mg})$

$\mathrm{T}=$ current year

$\mathrm{L}_{0}=$ methane generation potential $\left(\mathrm{m}^{3} / \mathrm{Mg}\right.$ of waste)

$\mathrm{k}=$ methane generation rate constant $(1 / \mathrm{yr})$

For this equation, for waste landfilled in the first year $1(x=1)$, the methane emission from this waste can be calculated in the same year $1(T=1)$. The amount generated would be:

$$
\mathrm{Q}_{1,1}=\mathrm{k} \times \mathrm{R}_{\mathrm{x}} \times \mathrm{L}_{0} \times \mathrm{e}^{-\mathrm{k}(1-1)}=\mathrm{k} \times \mathrm{R}_{\mathrm{x}} \times \mathrm{L}_{0}
$$

This is also the current interpretation observed in the first CDM projects that were based on this publication: emission starting since the year of waste disposal.

Eq. (A4) will be later examined in IPCC (2006) guidelines ${ }^{2}$, when it is shown that it always underestimate the emissions. A problem arises from the fact that a continuous event (namely methane formation) is treated as a discrete one. In showing their arguments, the authors of IPCC (2006) indicate that the first emission (year $T=1$ ) would be calculated from the waste placed in year $0(x=0)$, using the variables of eq. (A4), as the decreasing exponential function starts from time zero. For a constant $k$ representing a half-life of 10 years, the underestimation would be about $3.5 \%$ comparing with the full mass balance calculations.

However, with the current interpretation, first emission calculated with the maximum of the curve, there will be an overestimation. Apparently, the error should just change signal, the difference to the full mass balance calculation being an overestimation of about $3.5 \%$. Nevertheless, in addition to calculating the first emission with the maximum of the curve, the current interpretation is also in the sense of anticipation the emissions in one year. The calculation in year $0(T=0)$ is done since the year of disposal, year $0(x=0)$, as if the waste disposed in this year were emitting since the beginning of this year, at $1^{\text {st }}$ January (when $\mathrm{e}^{0}=1$ ). In this case, the overestimation is variable compared to the full mass balance calculation, considering the emission curve starting from the first day of next year. As will be shown later in a simulation case, for the same decay constant, the increase is $3.8 \%$ in the long term, but $23.9 \%$ in the first 10 years, and $35.1 \%$ in the first 7 years in relation to the amount indicated by the correct integration of the curve in such periods.

The error here is important in actual situations, especially if there is a significant variation in the amounts of waste disposed of in recent years or in case of new landfills, as in the case of several CDM projects that followed this methodology.

\footnotetext{
${ }^{1}$ Reference Manual, Equation 4, Chapter 6, page 6.11.

${ }^{2}$ Volume 5 - Waste, Chapter 3, item 3 A1.6.1, page 3.38.
} 


\subsection{Good Practice Guidance and Uncertainty Management in National Greenhouse Gas Inventories (IPCC, 2000)}

This publication intended to improve some of the methodologies provided in IPCC (1997) guidelines. For emissions from solid waste disposal sites (SWDS), the FOD model $^{3}$ is represented as:

$$
\begin{array}{r}
\mathrm{CH}_{4} \text { generated in year } \mathrm{t}(\mathrm{Gg} / \mathrm{yr})= \\
\sum_{\mathrm{x}}^{\mathrm{t}}\left[\left(\mathrm{A} \times \mathrm{k} \times \operatorname{MSW}_{\mathrm{T}}(\mathrm{x}) \times \mathrm{MSW}_{\mathrm{F}}(\mathrm{x}) \times \mathrm{L}_{0}(\mathrm{x})\right) \times \mathrm{e}^{-\mathrm{k}(\mathrm{t}-\mathrm{x})}\right]
\end{array}
$$

where:

$\mathrm{t}=$ year of inventory

$\mathrm{x}=$ years for which input data should be added

$\mathrm{A}=\left(1-\mathrm{e}^{-\mathrm{k}}\right) / \mathrm{k}$; normalization factor which corrects the summation

$\mathrm{k}=$ Methane generation rate constant $(1 / \mathrm{yr})$

$\operatorname{MSW}_{\mathrm{T}}(\mathrm{x})=$ Total municipal solid waste $(\mathrm{MSW})$ generated in year $x(\mathrm{Gg} / \mathrm{yr})$

$\operatorname{MSW}_{\mathrm{F}}(\mathrm{x})=$ Fraction of MSW disposed at SWDS in year $x$

$\mathrm{L}_{0}(\mathrm{x})=$ Methane generation potential $\left[\mathrm{MCF}(\mathrm{x}) \times \mathrm{DOC}(\mathrm{x}) \times \mathrm{DOC}_{F} \times \mathrm{F} \times 16 /\right.$

$12(\mathrm{Gg} \mathrm{CH} / \mathrm{Gg}$ waste $)]$

$\operatorname{MCF}(\mathrm{x})=$ Methane correction factor in year $\mathrm{x}$ (fraction)

DOC $(\mathrm{x})=$ Degradable organic carbon $(\mathrm{DOC})$ in year $\mathrm{x}$ (fraction) $(\mathrm{Gg} \mathrm{C} / \mathrm{Gg}$ waste)

DOC $_{F}=$ Fraction of DOC dissimilated

$\mathrm{F}=$ Fraction by volume of $\mathrm{CH}_{4}$ in landfill gas

$16 / 12$ = Conversion from $\mathrm{C}$ to $\mathrm{CH}_{4}$

Similarly, by this equation, the emission of methane from the waste disposed at the landfill in year $1(x=1)$ can be calculated in the same year $1(t=1)$. In order to compare the FOD models, it is very important to calculate the first emission, using discrete years, being aware of the first disposal year.

Eq. (A6) can be reduced to eq. (A2) unless the so-called "normalization" factor A. This factor arises from the solution of the definite integral for the negative exponential function representing the methane emissions, from year $t$ to year $t+1$ regarding the amount of waste disposed in a past year $x$.

There is a difficulty in this mathematical deduction, as indicated in IPCC (2006) guidelines ${ }^{4}$, when it says that, by resulting from the integration from year $t$ to year $t+1$, the equation fails to count the methane emission in the first year. For a constant $k$ representing a half-life of 10 years, the underestimation would be about $7 \%$ comparing with the emission calculated by using the exact integration of the curve.

However, this reasoning in IPCC (2006) guidelines reveals the interpretation that emissions are not to be calculated in the first year of waste disposal, unlike the current interpretation, as observed in national inventories and CDM projects that use this methodology. It also reveals that the correct interpretation of eq. (A6) is that emissions should start being calculated in year $t=2$ for residues disposed during the year $x=1$, using the variables as defined in this model.

IPCC (2006) guidelines have the correction for the normalization factor in eq. (A6) so that the integration is done correctly from year $t-1$ to year $t$, using the formula

\footnotetext{
${ }^{3}$ Equation 5.1, Chapter 5, page 5.6.

${ }^{4}$ Volume 5 - Waste, Chapter 3, item 3 A1.6.2 page 3.38.
} 


$$
A^{\prime}=\left(\frac{1}{e^{-k}}-1\right) / k=\frac{\left(e^{k}-1\right)}{k}
$$

with the understanding that emissions are always calculated from the year after disposal.

In other words, an amount of waste disposed during the year 1 can be considered, on average, that was placed at the landfill all at once in the middle of the year, i.e., $1^{\text {st }}$ of July. Furthermore, there is a typical delay of six months, not presented in the previous guidelines, (IPCC, 1997) and (IPCC, 2000), to the beginning of the anaerobic digestion process, which means that methane emissions start occurring on $1^{\text {st }}$ of January of year 2. This interpretation generates two consequences:

- There is a right shift of one year in the negative exponential curve of emissions;

- Emissions that occur during the year 2 must be calculated by the definite integral from the end of year 1 to the end of year 2. Or, generically, from the year $t-1$ to year $t$, the year in which the emission is supposed to be calculated.

It must be remembered that methane emissions in a given year is the sum of contributions of all amounts disposed in previous years, since the beginning of the landfill.

The underestimation error of $7 \%$ indicated in IPCC (2006) for the model of IPCC (2000) is valid with the interpretation of emissions beginning in the year after disposal. With the current understanding that emissions are calculated in the same year of disposal, there will be overestimation. For the simulation case shown in this thesis, although there is a negligible increase in the long-term $(0.3 \%)$, the increase will be $19.7 \%$ in in the first 10 years and $30.5 \%$ in in the first 7 years in relation to the amount indicated by the proper integration of the curve in such periods.

The error here is also important, especially if the amounts of disposed waste have varied significantly in previous years or in case of new landfills.

\subsection{CDM Methodological Tool (UNFCCC, 2012)}

For project activities on biogas from SWDS seeking registration under the CDM, the following equation should be used for an ex-ante evaluation of the amount of methane, measured in $\mathrm{CO}_{2} \mathrm{e}^{5}$ :

$$
\begin{gathered}
\mathrm{BE}_{\mathrm{CH} 4, \mathrm{SWDS}, \mathrm{y}}=\varphi_{\mathrm{y}} \times\left(1-\mathrm{f}_{\mathrm{y}}\right) \times \mathrm{GWP}_{\mathrm{CH} 4} \times(1-\mathrm{OX}) \times \frac{16}{12} \times \mathrm{F} \times \mathrm{DOC}_{\mathrm{f}, \mathrm{y}} \\
\times \mathrm{MCF}_{\mathrm{y}} \times \sum_{\mathrm{x}=1}^{\mathrm{y}} \sum_{\mathrm{j}} \mathrm{W}_{\mathrm{j}, \mathrm{x}} \times \mathrm{DOC}_{\mathrm{j}} \times \mathrm{e}^{-\mathrm{k}_{\mathrm{j}}(\mathrm{y}-\mathrm{x})} \times\left(1-\mathrm{e}^{-\mathrm{k}_{\mathrm{j}}}\right)
\end{gathered}
$$

where:

$\mathrm{BE}_{\mathrm{CH} 4, \mathrm{SWDS}, \mathrm{y}}=$ Baseline methane emissions occurring in year $y$ generated from waste disposal at a SWDS during a time period ending in year $y\left(\mathrm{t} \mathrm{CO}_{2} \mathrm{e} / \mathrm{yr}\right)$

$\mathrm{x}=$ Years in the time period in which waste is disposed at the SWDS, extending from the first year in the time period $(x=1)$ to year $y(x=y)$.

\footnotetext{
${ }^{5}$ Carbon dioxide equivalent, based on the relative radiating forces of the gases measured by Global Warming Potential - GWP.
} 
$y=$ Year of the crediting period for which methane emissions are calculated ( $y$ is a consecutive period of 12 months)

$\mathrm{DOC}_{\mathrm{f}, \mathrm{y}}=$ Fraction of degradable organic carbon (DOC) that decomposes under the specific conditions occurring in the SWDS for year $y$ (weight fraction)

$\mathrm{W}_{\mathrm{j}, \mathrm{x}}=$ Amount of solid waste type $j$ disposed in the SWDS in the year $x(\mathrm{t})$

$\varphi_{\mathrm{y}}=$ Model correction factor to account for model uncertainties for year $y$

$\mathrm{f}_{\mathrm{y}}=$ Fraction of methane captured at the SWDS and flared, combusted or used in another manner that prevents the emissions of methane to the atmosphere in year $y$

$\mathrm{GWP}_{\mathrm{CH} 4}=$ Global Warming Potential of methane

$\mathrm{OX}=$ Oxidation factor (reflecting the amount of methane from SWDS that is oxidized in the soil or other material covering the waste)

$\mathrm{F}=$ Fraction of methane in the SWDS gas (volume fraction)

$\mathrm{MCF}_{\mathrm{y}}=\mathrm{Methane}$ correction factor for year $y$

$\mathrm{DOC}_{\mathrm{j}}=$ Fraction of degradable organic carbon in the waste type $j$ (weight fraction)

$\mathrm{k}_{\mathrm{j}}=$ Decay rate for the waste type $j(1 / \mathrm{yr})$

$\mathrm{j}=$ Type of residual waste or types of waste in the MSW

Eq. (A8), or simply CDM Tool, is used for annual calculations, and takes into account the constituent fractions of the residue, treating each fraction $j$ independently of the others, with its own constant $k_{j}$ and potential methane generation $L_{0 j}$. It calculates emissions in $\mathrm{t}^{\mathrm{CO}_{2} \mathrm{e}}$ (with the term $\mathrm{GWP}_{\mathrm{CH}}$ ), takes into account the part of methane that is oxidized while passing through the surface layer of the landfill (with the fraction $O X$ ), and the fraction that would be burned in the absence of the project activity (with the fraction $f_{y}$ ). The factor $M C F_{y}$ is based on the quality of the disposal site in year $y$, with a default value of $M C F=1$ for landfills, the case of this comparative study.

This equation will be simplified here with the following assumptions: calculation only for methane (with the removal of the term $\left.G W P_{C H 4}\right)$; no methane captured $\left(f_{y}\right.$ equal to zero); without oxidation by the surface ( $O X$ equal to zero); and just a single fraction $j$ of the residue contributing to the emissions in the year $x$ :

$$
\begin{aligned}
\mathrm{BE}_{\mathrm{CH} 4, \mathrm{SWDS}, \mathrm{y}}= & \varphi_{\mathrm{y}} \times\left(1-\mathrm{e}^{-\mathrm{k}_{j}}\right) \times \mathrm{W}_{\mathrm{j}, \mathrm{x}} \times\left[\frac{16}{12} \times \mathrm{F} \times \mathrm{DOC}_{\mathrm{f}, \mathrm{y}} \times \mathrm{DOC}_{\mathrm{j}}\right] \\
& \times \mathrm{e}^{-\mathrm{k}_{j}(\mathrm{y}-\mathrm{x})}
\end{aligned}
$$

The term in brackets of eq. (A9) is the methane generation potential $L_{0}$ (with different values for each waste type $j$ ):

$$
\mathrm{BE}_{\mathrm{y}}=\varphi_{\mathrm{y}} \times\left(1-\mathrm{e}^{-\mathrm{k}}\right) \times \mathrm{W}_{\mathrm{x}} \times \mathrm{L}_{0} \times \mathrm{e}^{-\mathrm{k}(\mathrm{y}-\mathrm{x})}
$$

where the factor $\varphi_{y}$ accounts for the model uncertainties. In an approach with no uncertainty for the terms $W, D O C, D O C_{f}, F, M C F_{y}$, and $\mathrm{e}^{-\mathrm{k}(\mathrm{y}-\mathrm{x})} \times\left(1-\mathrm{e}^{-\mathrm{k}}\right)$ so that $\varphi_{y}$ equals 1 , then eq. (A10) can be identified to eq. (A6), remembering that $A \times$ $k=\left(1-e^{-k}\right)$. Therefore, the CDM methodology for calculating baseline emissions of a landfill has the same intrinsic error of IPCC (2000) model, which was pointed out in IPCC (2006) guidelines, as discussed in section 2.2. Similarly to IPCC (2000), the current interpretation of this methodology as observed in CDM 
projects is that emissions are calculated from the year of disposal.

In order to correct this model, eq. (A8) should be modified by replacing the term $\left(1-e^{-k_{j}}\right)$ by $\left(e^{k_{j}}-1\right)$ and be calculated with the IPCC (2006) interpretation: emissions from the year after disposal.

\subsection{IPCC Guidelines for National Greenhouse Gas Inventories (IPCC, 2006)}

The guidelines in IPCC (2006) are more cautious when dealing with a continuous phenomenon reported by discrete values. It also takes into account the actual delay observed in the waste decomposition by methanogenic bacteria. The First Order Decay model for estimating methane emissions from solid waste disposal sites is based on two main equations ${ }^{6}$ that could be said to be the core of the model:

DDOCm, mass of decomposable DOC deposited, accumulated in the SWDS at the end of year $T$ :

$$
\mathrm{DDOCma}_{T}=\text { DDOCmd }_{T}+\left(\text { DDOCmd }_{T-1} \times \mathrm{e}^{-\mathrm{k}}\right)
$$

DDOCm decomposed at the end of year $T$ :

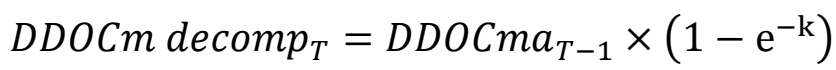

where:

$\mathrm{T}=$ inventory year

$D D O C m a_{T}=$ DDOCm accumulated in the SWDS at the end of year $T, \mathrm{Gg}$

$D_{D O C m a} a_{T-1}=$ DDOCm accumulated in the SWDS at the end of year $(T-1)$, $\mathrm{Gg}$

DDOCmd $_{T}=$ DDOCm deposited into the SWDS in year T, Gg

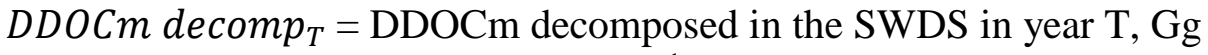

$\mathrm{k}=$ reaction constant, $\mathrm{k}=\ln (\mathrm{A} 2) / \mathrm{t}^{1} / 2\left(\mathrm{y}^{-1}\right)$

$\mathrm{t} 1 \frac{1}{2}=$ half-life time $(\mathrm{y})$

Eq. (A11) and eq. (A11)indicate the practical way to calculate the carbon that will decompose in a given year, from the mass of carbon available at the end of the previous year.

IPCC (2006) guidelines provide several options to determine the values for the reaction constant $k$ and other parameters that are part of the calculation of degradable carbon available for the anaerobic process, for each residue fraction type. Furthermore, there is the consideration of a delay in the waste decomposition. A default value of six months is provided, generating emissions only in the year after disposal, but solutions for smaller and higher delays are also presented. IPCC (2006) guidelines provide a spreadsheet to integrate all parameters and information necessary to determine methane emissions from solid waste disposal, offering as a by-product a calculation of amounts of harvested wood products in general, which are long-term stored in landfill sites, to assist the balance of carbon stocks needed in the sector agriculture/forestry of a national inventory.

\subsection{Scholl-Canyon}

\footnotetext{
${ }^{6}$ Volume 5 - Waste, First Order Decay basics, page 3.9.
} 
World Bank (2004) introduces Scholl-Canyon model as the empirical, first-order decay model most widely accepted and used by industry and regulatory agencies, including the US-EPA. The first order equation is defined as:

$$
Q_{C H 4 i}=k \times L_{0} \times m_{i} \times \mathrm{e}^{-\mathrm{k} t_{i}}
$$

$\mathrm{Q}_{\mathrm{CH} 4 \mathrm{i}}=$ methane produced in year $i$ from the $i^{\text {th }}$ section of waste

$\mathrm{k}=$ methane generation constant

$\mathrm{L}_{0}=$ methane generation potential

$\mathrm{m}_{\mathrm{i}}=$ waste mass disposed of in year $i$

$\mathrm{t}_{\mathrm{i}}=$ years after closure

This model is very similar to the IPCC (1997) model described by eq. (A4). There is not much indication on how the time variable should be used but from the table showing the calculations in an example, it can be seen that the amount of waste placed in one year will begin emitting methane since the following year and with the maximum of the exponential function in this year. In this case, the difference to the full mass calculation is an overestimation of about $3.5 \%$ as just explained in the analysis of IPCC (1997) model.

However, it worth saying that one of the cases presented in World Bank (2004), Marambaia-Adrianópolis landfills - the CDM NovaGerar activity project - said to use this model, does not use this approach but calculates emissions since the year of deposition, as will be seen in this thesis .

\subsection{LandGEM Version 3.02}

US-EPA (2005-a) describes the Landfill Gas Emissions Model (LandGEM) Version 3.02. The model comes in an Excel spreadsheet that provides defaults based on empirical data from U.S. landfills but allowing other values. It can be used both for U.S. regulations and for inventories. The model can also provide estimation for several pollutants but this thesis only focus methane results. The first order equation is defined as:

$$
Q_{C H 4}=\sum_{i=1}^{n} \sum_{j=0.1}^{1} k \times L_{0} \times\left(\frac{M}{10}\right) \times \mathrm{e}^{-\mathrm{k} t_{i j}}
$$

where:

$\mathrm{Q}_{\mathrm{CH} 4}=$ annual methane generation in the year of the calculation $\left(\mathrm{m}^{3} /\right.$ year $)$

$\mathrm{i}=1$ year time increment

$\mathrm{n}=($ year of the calculation $)-($ initial year of waste acceptance $)$

$\mathrm{j}=0.1$ year time increment

$\mathrm{k}=$ methane generation rate $\left(\right.$ year $\left.^{-1}\right)$

$\mathrm{L}_{0}=$ potential methane generation capacity $\left(\mathrm{m}^{3} / \mathrm{Mg}\right)$

$\mathrm{M}_{\mathrm{i}}=$ mass of waste accepted in the $i^{\text {th }}$ year $(\mathrm{Mg})$

$\mathrm{t}_{\mathrm{ij}}=$ age of the $j^{\text {th }}$ section of waste mass $M_{i}$ accepted in the $i^{\text {th }}$ year (decimal years, e.g.,

\section{2 years $)$}

The intention behind this model is to treat the continuous process in smaller time intervals in order be closer to a real integration of the methane generation function. Like the IPCC (2006) model, this one calculates emissions since the year after 
disposal.

Considering a landfill receiving wastes with a constant $k$ representing a half-life of 10 years, this model gives results with just $0.3 \%$ of overestimation in relation to the exact integration of the curve.

\subsection{How these models are used and how do their results differ from each other?}

IPCC guidelines are intended for national GHG inventory calculations but are also used for single landfills. Parties under the UNFCCC should use these guidelines for their inventories, although in different ways: developing countries are encouraged to use IPCC (2000) ${ }^{7}$ guidelines, but it is mandatory for developed countries, although they may also use national methodologies which they consider better able to reflect their national situation, provided that these methodologies are compatible with UNFCCC requirements ${ }^{8}$. IPCC (2006) guidelines will be mandatory (with the same previous remark) for developed countries starting from their 2015 submissions to the $\mathrm{UNFCCC}^{9}$, although all countries can use the latter methodology once they find appropriate for their particular situation. The use of IPCC (1997) guidelines for emissions from SWDS is now less common.

Regarding the CDM projects dealing with biogas from landfills, the methodological tool is mandatory for all cases. The model has the same issue discussed here since its initial adoption, in 2006. This tool is also used to estimate emissions that would occur in the absence of projects that prevent biomass from being disposed of in landfills, by using aerobic carbon transformation, e.g., by incineration or composting.

For the sake of comparison, a hypothetical case of disposal in a landfill of 100,000 tonnes of waste for 20 years since 2001 is modelled with the various options, for which the related parameters are shown in Table 1.

Table 1 - Parameters used in models

\begin{tabular}{|c|c|c|c|c|c|c|c|c|}
\hline \multicolumn{2}{|c|}{ Option } & $k$ & $L_{0}$ & $W_{j}$ & $k$ & $D O C$ & $D O C_{f}$ & $\begin{array}{c}\mathrm{CH}_{4} \\
\text { density }\end{array}$ \\
\hline \multicolumn{2}{|l|}{ Bulk } & 0.0693 & $\begin{array}{c}75.4 \mathrm{~m}^{3} \\
\mathrm{CH}_{4} / \mathrm{t} \\
\text { waste }\end{array}$ & & & & & \multirow{5}{*}{$\begin{array}{c}0.7168 \\
\mathrm{~kg} / \mathrm{m}^{3}\end{array}$} \\
\hline \multirow{4}{*}{ Fractions } & Wood & & & $4.7 \%$ & 0.035 & $43 \%$ & \multirow{4}{*}{$50 \%$} & \\
\hline & Pulp\&paper & & & $17.1 \%$ & 0.07 & $40 \%$ & & \\
\hline & Food & & & $44.9 \%$ & 0.4 & $15 \%$ & & \\
\hline & Textiles & & & $2.6 \%$ & 0.07 & $24 \%$ & & \\
\hline
\end{tabular}

In Table 1, for the bulk option, the value of the decay constant $k$ is related to a half-life of 10 years, and the value for the methane generation potential $L_{0}$ was calculated with the parameters of the fractions option. For this second option, the parameters have default values from IPCC (2006) guidelines, for South America, in a tropical/wet situation, the same values considered in the CDM Tool. In addition, there is no uncertainty factor, no oxidation in the upper layer of the landfill, no destruction of methane, and perfect anaerobic condition.

Methane emissions and relative differences are shown in Table 2 for each case.

\footnotetext{
${ }^{7}$ UNFCCC, 2002a.

${ }^{8}$ UNFCCC, 2002b.

${ }^{9}$ UNFCCC, 2013.
} 
As this table has short column headings in order to spare space, a brief explanation could help the reader to identify each combination model-option-parameterinterpretation referred to. The models using the bulk option will be compared to the exact IPCC (2006) bulk option (column I), and the ones using the fractions option will be compared to the exact IPCC (2006) fractions option (column J).

The models using the bulk option appear in the first columns. The current interpretation for IPCC (1997) and IPCC (2000) - emissions calculated since the year of disposal and with the maximum value for the exponential curve - are in columns A and D, respectively. The interpretation of IPCC (2006) guidelines for IPCC (1997) and IPCC (2000) models - emissions calculated since the year after disposal - are in columns B and E, respectively. The interpretation of IPCC (2006) guidelines for IPCC (1997) model - emissions calculated since the year after disposal however using the current interpretation of estimating the first emission with the maximum value for the exponential curve - is in column C. IPCC (2000) model using the correction that should be applied to the normalization factor, with the definition by eq. (A12), and emissions calculated since the year after disposal is in column $\mathrm{F}$.

The CDM Tool model uses the fraction option. The current interpretation for the CDM Tool model - emissions calculated since the year of disposal - is in column G. The CDM Tool model incorporating the corrections proposed in this paper and with the emissions calculated since the year after disposal is in column $\mathrm{H}$.

In this exercise, it worth noting that bulk DOC is equal to the combined DOC of the fractions but there are different decay constants in both options, leading to differences in the first years.

As seen in Table 2, the approach provided in the IPCC (2000) guidelines and in the CDM Tool, respectively for national inventories and CDM projects - with the proposed corrections - have the effect of shifting the emission curve one year later compared to the models without corrections. In the case of inventories, if long time series are used and there are not significant changes in the amounts of waste landfilled yearly, the overall difference tends to be negligible.

On the other hand, as CDM project activities usually deal with varying quantities of waste and with short periods requesting carbon credits ${ }^{10}$, differences have great importance. Figure 1 shows CDM Tool model in its two versions, actual and modified (columns $\mathrm{G}$ and $\mathrm{H}$ ). In a new landfill, the actual model will result in an overestimation of $24.9 \%$ for the first seven years; and of $15.8 \%$ for the first ten years, compared to the IPCC (2006) exact model, and that would lead to lower than expected results. If the project activity is intended to use the biogas after the landfill closure, the actual model will indicate an underestimation of circa $10 \%$ for both periods of seven and ten years after closure, which could prevent the project from being implemented. If the CDM project activity is about preventing biomass from being landfilled, overestimation automatically means issuing more carbon credits than due, jeopardizing the environmental integrity of the Kyoto Protocol.

${ }^{10}$ A CDM project activity can choose between a 7-year period for its first crediting period, with possible renewal of two more 7 -year period or a 10 -year period without renewal. 
Table 2 - Simulation case: emissions calculated by the models referred to in this thesis

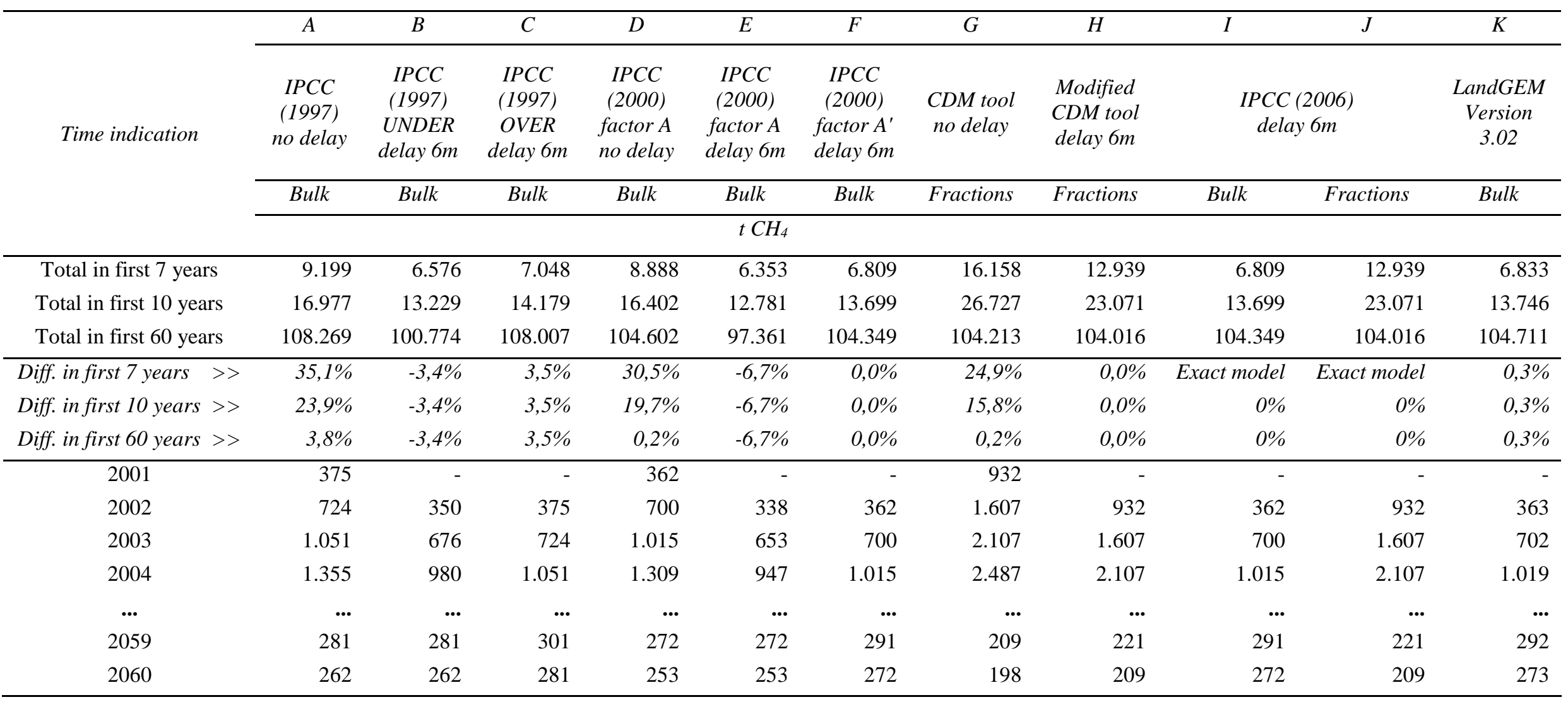


The same simulation case can be analyzed in another way. Suppose the CDM project activity selects one particular year for the beginning of a 7-year crediting period. Figure 2 shows the differences from the actual CDM Tool to the IPCC (2006) exact model - or the modified CDM Tool as proposed in this thesis - for each possible starting year.

Therefore, errors exist in every situation, with different consequences. As long significant changes in the amounts of landfilled waste occur, differences in the expected emissions tend to be important.

The current interpretation of emissions beginning since the first year of disposal can be seen in the project activities available in the CDM website ${ }^{11}$, where the project design documents are available together with spreadsheets providing calculations. For example, in the "Landfill gas recovery, energy generation and biogas distribution from CTR Santa Rosa", a special type of CDM project that is under a Programme of Activities named "Caixa Econômica Federal Solid Waste Management and Carbon Finance Project", related to the new landfill serving the municipality of Rio de Janeiro in Brazil, which started operations in 2011. The spreadsheet "ER calculations.xls", sheet "Inputs \& Calculations", shows emissions calculated with the CDM Tool since the year of disposal of wastes. The expected methane emissions for its 7-year crediting period beginning in 2012 has an overestimation of $18 \%$ in relation to the exact model.

\subsection{Evaluating Generation Models Used In CDM Projects}

To evaluate a mathematical prediction model is necessary to use it, with certain data, and make a confrontation with actual results achieved. Therefore, one possible approach would be the direct measurement of gases emanating from a landfill, by means of various methods. Oonk (2010) indicates several of them: measurements of soil samples taken from various depths of the coverage; measurements using closed chambers; micrometeorological measurements on a plane above the landfill; measurements by sections / mass balances; tracer plume measurements; plume measurements; qualitative emissions measurements. All have advantages and disadvantages and can be combined, but require much fieldwork and resources.

Another approach is to use the recovered amounts of methane, as intended in this thesis, based on data obtained through the structure of the CDM. According to Oonk (2010), the amount of methane generation can be obtained by knowing the extraction efficiency $(\eta)$ and the amount captured ${ }^{12}$ :

$$
\text { methane generation }=\text { methane recovery } / \eta
$$

But then he says there are two prerequisites for this approach: firstly, the amount recovered has to be limited by generation and not by the possibility of utilization of the landfill gas (e.g., limited burning capacity); and secondly, landfill gas recovery is state of the art, meaning that sufficient recovery wells are used, gas recovery also in parts of the landfill that are currently exploited, biweekly control and adjustment of under-pressure on the wells.

\footnotetext{
${ }^{11}$ Link http://cdm.unfccc.int/.

${ }^{12}$ This equation is now in its correct form (Oonk, 2014).
} 


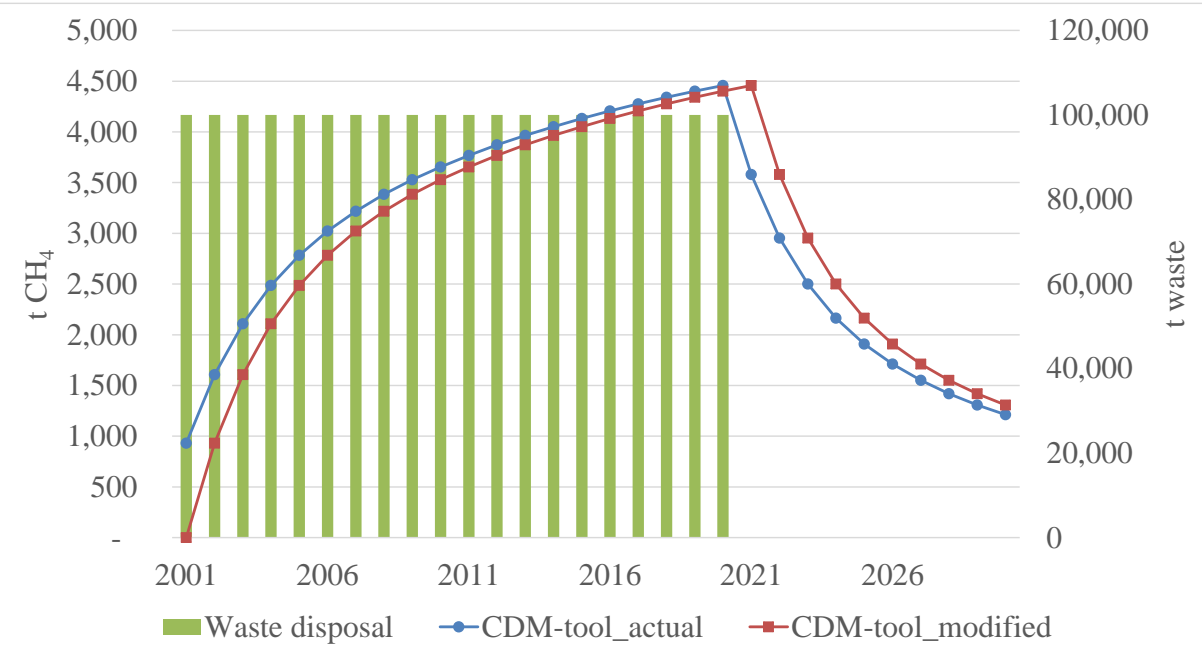

Figure 1 - Comparison of CDM Tool models: actual and modified

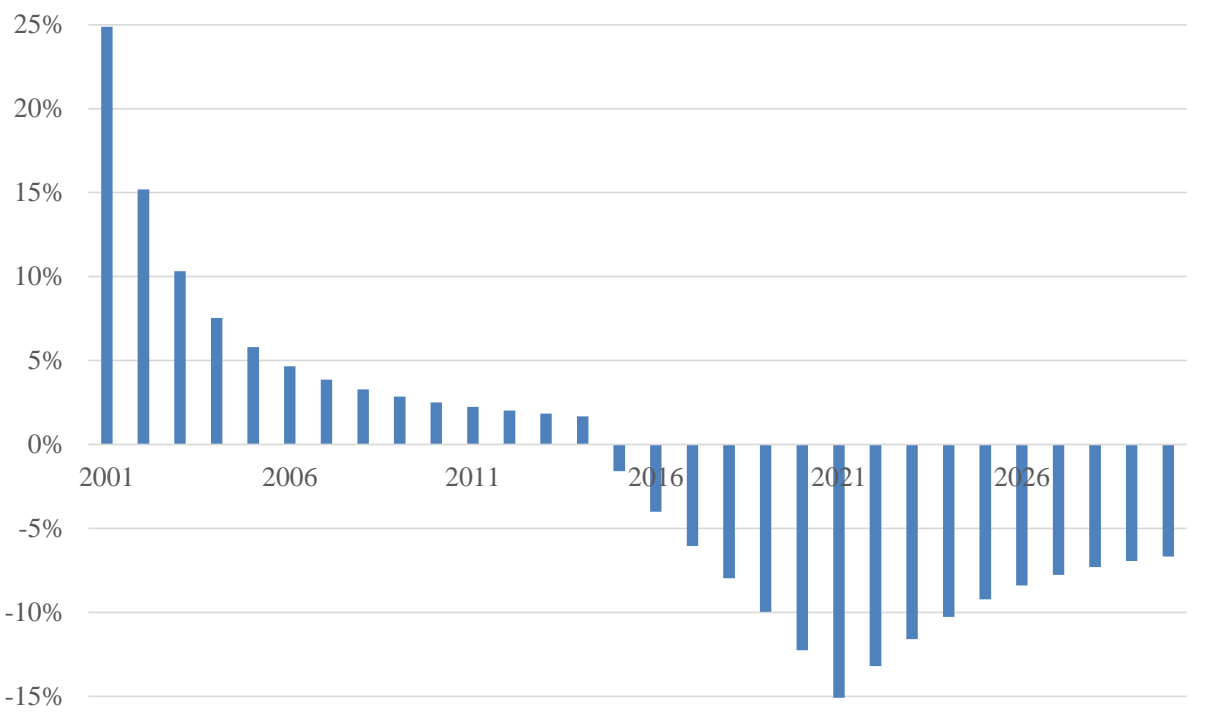

Figure 2 - Comparison of CDM Tool models: actual and modified, for projects with a 7-year crediting period varying the initial year

In the case of CDM projects involving landfill gas, the important point is to capture and destroy as much methane as possible, since this quantity will be translated into carbon credits and then sold to interested developed countries or used by investors countries, which means to meet the resources / credits expectation that was crucial to the decision to do the project. CDM projects can simply burn the methane without energy generation or use it preferably for driving electric generators, and for this utilize state of art design, often being organized by foreign companies, as expected by the Kyoto Protocol. It is always worth remembering that carbon credit trade is a powerful reason for the application of the best technologies in these projects in order to maximize the emission reduction results. Therefore, get checked the prerequisites required by Oonk (2010) to use the amounts of recovered methane for comparison with generation models. eq. (A15) will be slightly modified to estimate, for each prediction model $i$, the project activity efficiency, by 
using the methane recovery amounts:

$$
\eta_{\text {Model } i}=\text { methane recovery } / \text { methane generation }_{\text {Model } i}
$$

Since the mathematical models can use different parameters, yielding different estimates, the project activity efficiency must be evaluated according to each model/parameters set, which can be independently done year after year, and then compared with the planned project efficiency.

As the carbon credits generated by CDM projects will assist other countries to meet their reduction targets required by legally binding international agreement, every caution is taken during the process to ensure the integrity of the mechanism. A project activity can only use a methodology approved by the CDM Executive Board, scientifically supported by a Methodologies Panel, with detailed conditions and steps to be followed, even maintenance frequency for measuring instruments. A Designated Operational Entity (DOE) acting on behalf of the Executive Board should validate the compliance with the methodology. During the project life, another DOE will be required to verify and approve monitoring reports that will be issued throughout the years.

Calculations of expected methane generation as contained in the Project Design Document (PDD) have been redone and checked using the same model. From the periodic monitoring reports, methane recovery amounts were revealed. When available in these reports, information on differences to the expected results has been highlighted, since this became mandatory after a certain date. Care was taken to consider only the latest version of the monitoring reports, given that they often change during the process of verification and certification and that the availability of all versions is a point of confusion.

\section{THE LANDFILLS}

The landfills studied here had their potential for biogas evaluated at their inception and which later on had their generation models and their parameters re-evaluated. This is done upon renewal of their first 7-year crediting period, according to the $\mathrm{CDM}$ procedures, when it is necessary to update the baseline and monitoring methodology. Only four CDM projects in Brazil fell under this condition in May 2014.

\subsection{Brazil NovaGerar Landfill Gas to Energy Project - Ref 0008}

It has two sites: Marambaia, working from 1988 to 2002 and Adrianópolis, starting in 2003. First crediting period from 01 July 2004 to 30 June 2011, but the project was operational only since 15 March 2007 . The second period only considers Adrianópolis site. Monitoring reports cover the period up to 31 December 2012.

In the first PDD, the model used is IPCC (1997), with emission maximum since the year of disposal; in the second PDD (Nov 2011), the CDM Tool model is used, and there is an update of the waste amounts disposed of in the past seven years. Only Adrianópolis will be treated here. 


\subsection{Bandeirantes Landfill Gas to Energy Project (BLFGE) - Ref 0164}

The landfill received waste from 1979 to 2007. The first crediting period ranges from 2004 to 2010. Monitoring reports cover the period up to 31 August 2012.

In the first PDD, the IPCC (1997) model is used, with emission maximum since the year of disposal; in the second PDD (March 2012), the CDM Tool model is used, and there is an update of the waste amounts disposed of in the past seven years.

\subsection{ESTRE's Paulínia Landfill Gas Project (EPLGP) - Ref 0165}

The landfill receives waste since 2000. The first crediting period ranges from 2006 to 2012. Nevertheless, the first PDD has been revised (January 2012) for corrections, not only on the crediting period, now ranging from 14 September 2006 to 13 September 2013, but also the yearly waste amounts disposed of and model parameters. Monitoring reports cover the period from 14 September 2006 to 30 September 2012.

In the first PDD (either version), the IPCC (1997) model is used, with emission maximum since the year of disposal; in the second PDD (June 2013), the CDM Tool model is used, and there is an update of the waste amount disposed of in 2012.

\subsection{Caieiras landfill gas emission reduction - Ref 0171}

The landfill receives wastes since 2002. The first crediting period ranges from 31 March 2006 to 30 March 2013 but the project was operational only since 01 February 2007. Nevertheless, the first PDD has been revised (January 2013) for significant corrections concerning the yearly waste amounts and the type of model. Monitoring reports cover the period from 01 February 2007 to 30 September 2012.

In the first PDD (revised version), the IPCC (2000) model is used, with emission maximum since the year of disposal; in the second PDD (September 2013), the CDM Tool model is used.

\section{RESULTS AND DISCUSSION}

Extraction efficiencies - for each model - were calculated after the monitored methane extraction amounts were recovered from the final monitoring reports, which cover uninterrupted periods. Whenever necessary, the beginning years or the final years of these periods were completed based on daily averages, so as to permit full year comparison. In such way, 73 days were added in 2007 for Adrianópolis; for Bandeirantes, 122 days were added in 2012; for ESTRE's-Paulínia, 256 days were added in 2006, and 92 days in 2012; for Caieiras, 31 days were added in 2007, and 92 days in 2012.

In order to allow comparison among the models used in different opportunities for each landfill, care was taken with:

- All the calculations have been redone in order to check the PDDs, following the indicated parameters. In the first PDDs there was no worksheet available, except for ESTRE's Paulínia; for the second ones, worksheets were available in the CDM site. To arrive at the results presented in PDDs, some corrections in the 
parameters were necessary as indicated by the reverse calculations. In one case, a double discount related to the oxidation factor was found.

- In the first PDDs, no oxidation factor was used. As this can be added simply in the end, this factor is used here in all models for final comparison.

- Only in the CDM Tool model there is an uncertainty factor. Prior to its version 06.0.0 of 25 November 2011, this factor was 0.9 , and then changing to 0.75 . This uncertainty factor did not exist in the first PDDs using IPCC (1997) or IPCC (2000) models. For comparison with the others, the CDM Tool model is presented here with three uncertainty factors: $1,0.9$ and 0.75 .

- As the second PDDs give actual values for the waste disposal amounts in the seven previous years, the updated values are used here for all models.

The values for $k$ and $L_{0}$ used for the landfills in the first PDDs are shown in Table 3 , along with the corresponding values suggested by IPCC (2006) for bulk waste, which depend on the parameters reveled in the second PDDs.

In the second PDDs, parameters $k_{j}, D O C_{j}$ are IPCC (2006) default values, considering that Caieiras has a temperate-wet condition and the others have a tropical-wet condition. Waste composition for each landfill is shown in Table 4. All have their own waste composition, except Caieiras that adopted IPCC (2006) default values for South America.

In Table 5 there is a summary of the information from PDDs and monitoring reports, including methane recovery for each landfill.

Table 3. Decay constant and methane potential used in the first PDDs

\begin{tabular}{lrrrrr}
\hline \multirow{3}{*}{ Landfill } & \multicolumn{4}{c}{ PDD-1 } \\
\cline { 2 - 5 } & \multicolumn{2}{c}{$k\left(\right.$ year $\left.^{-1}\right)$} & \multicolumn{2}{c}{$L_{0}\left(\mathrm{~m}^{3} \mathrm{CH}_{4}\right)$} & \multirow{2}{*}{ Model } \\
\cline { 2 - 5 } & \multicolumn{1}{c}{ Used } & IPCC 2006 & \multicolumn{1}{c}{ Used } & IPCC 2006 & \\
\hline Adrianópolis & 0.1 & 0.17 & 117.14 & 58.37 & IPCC 1997 \\
Bandeirantes & 0.102 & 0.17 & 84.10 & 73.01 & IPCC 1997 \\
ESTRE's Paulínia & 0.09 & 0.17 & 140.00 & 68.71 & IPCC 1997 \\
Caieiras & 0.08 & 0.09 & 115.78 & 75.43 & IPCC 2000 \\
\hline
\end{tabular}

Table 4. Waste fractions used in the second PDDs

\begin{tabular}{lccccc}
\hline \multicolumn{1}{c}{ Landfill } & $\begin{array}{c}\text { Wood and } \\
\text { wood } \\
\text { products }\end{array}$ & $\begin{array}{c}\text { Pulp, } \\
\text { paper and } \\
\text { cardboard }\end{array}$ & $\begin{array}{c}\text { Food,food } \\
\text { waste, } \\
\text { beverages } \\
\text { and tobacco }\end{array}$ & Textiles & $\begin{array}{c}\text { Garden, } \\
\text { yard and } \\
\text { park waste }\end{array}$ \\
\hline Adrianópolis & $0.8 \%$ & $18.0 \%$ & $48.7 \%$ & $3.9 \%$ & $0.0 \%$ \\
Bandeirantes & $0.7 \%$ & $12.3 \%$ & $60.6 \%$ & $3.1 \%$ & $3.2 \%$ \\
ESTRE's Paulínia & $1.2 \%$ & $17.4 \%$ & $41.6 \%$ & $4.3 \%$ & $0.0 \%$ \\
Caieiras & $4.7 \%$ & $17.1 \%$ & $44.9 \%$ & $2.6 \%$ & $0.0 \%$ \\
\hline
\end{tabular}


Table 5. General information of the landfill sites studied (from PDDs and monitoring reports)

\begin{tabular}{lcccccr}
\hline Landfill & Start & $\begin{array}{c}\text { Disposed } \\
\text { wastes } \\
\text { up to 2012 } \\
(t)\end{array}$ & $\begin{array}{c}\text { Projected } \\
\text { recovery } \\
\text { efficiency } \\
\text { in PDD-1 }\end{array}$ & $\begin{array}{c}\text { Number of } \\
\text { monitoring } \\
\text { reports }\end{array}$ & $\begin{array}{c}\text { Monitored } \\
\text { period }\end{array}$ & $\begin{array}{c}\text { Recovered } \\
\text { methane } \\
(t)\end{array}$ \\
\hline Adrianópolis & 2003 & $7,780,010$ & $85 \%$ & 6 & 6 years & 26,292 \\
Bandeirantes & 1979 & $37,226,873$ & $80 \%$ & 18 & 9 years & 232,075 \\
ESTRE's Paulínia & 2000 & $13,512,504$ & $80 \%$ & 14 & 7 years & 123,460 \\
Caieiras & 2002 & $20,234,148$ & $80 \% *$ & 7 & 6 years & 180,365 \\
\hline
\end{tabular}

* In 2007, the recovery efficiency was estimated in PDD as $70 \%$.

With the annual amounts of recovered methane and the estimation by each key model, the annual efficiencies were calculated for each year of the monitored periods. Maximum, minimum and average annual values are shown in Table 6 for each model. The first two are the model used in PDD-1 - IPCC (1997) model or IPCC (2000) model with factor A - and its correction as discussed here, the IPCC (2000) model with factor A' and delay. The other five models are options using data from PDD-2: the IPCC (2006) model with bulk option; the CDM Tool model and its correction, considering the uncertainty factor as 1, and the corrected CDM Tool model with uncertainty factor as 0.9 and 0.75 .

The results in Table 6 are showing methane overestimation in the first PDDs column A, which presents the lower figures, not only because of the model used, as discussed before, but also due to a higher value for $L_{0}$ in relation to IPCC (2006) defaults, as shown in Table 3. Or due to the assertion of Themelis and Ulloa (2007) that a methane generation of about $50 \mathrm{~m}^{3} \mathrm{CH}_{4} / \mathrm{t} \mathrm{MSW}$ is conservative. Note that if oxidation factor of $10 \%$ were not used for this comparison, the efficiencies would be even lower. The correction of the first model gives lower estimations and higher efficiencies, as per column B. If used IPCC (2006) bulk option - column C, the efficiencies would be even better except for Bandeirantes.

In the second PDDs, the fraction approach is used. The actual CDM Tool but without uncertainty factor - column D - already shows better efficiencies in relation to the first PDDs - column A - or its correction - column B, except in Caieiras. Column D can also be compared to the IPCC (2006) model in the bulk option column $\mathrm{C}$, where there are better results in two cases - Bandeirantes and ESTRE's Paulínia, but worse in Caireiras. The specific case of Caieiras will be analyzed further ahead.

If column D model is changed for its correction - column $\mathrm{E}$ - the improvement in relation to the columns A and B are true for all landfills. However, the comparison of column $\mathrm{E}$ with column $\mathrm{D}$ shows an efficiency reduction in Bandeirantes landfill. It should be noted that the variations in efficiency in the corrected CDM Tool model depend on the waste disposal time series, as said before. In this sense, the waste disposal at Bandeirantes landfill ending in 2007 explains the decreased efficiencies when CDM Tool model is corrected.

When the uncertainty factor is taken into account, as prescribed in the CDM Tool, methane estimations decrease, and efficiencies increase. This is clear by observing columns E, F, and G It seems that $\varphi=0.75$ leads to an excessive discount.

Adrianópolis has the lowers results, even lower if compared to the projected recovery efficiency of $85 \%$. This value will be reconsidered to be $40 \%$ in the second 
PDD, which is consistent with the assertion that a zone in operation that has no top cover and is connected to a biogas recovery system has a collection efficiency of 35\% (Scharff and Jacobs, 2006). However, maybe the main reason for a low efficiency is that, according to PDD-2, an extraction system was not in place for all areas receiving wastes.

Table 6. Extraction efficiencies (maximum, minimum, and average values, within the period of observation) for each considered landfill and model.

\begin{tabular}{|c|c|c|c|c|c|c|c|c|}
\hline \multirow[t]{2}{*}{ Landfill } & \multirow[t]{2}{*}{ 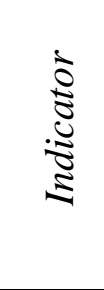 } & ลิ & 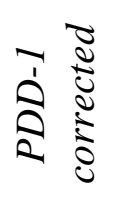 & 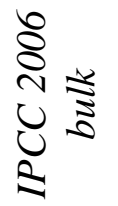 & 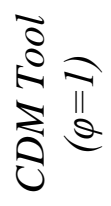 & 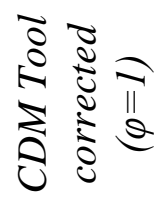 & 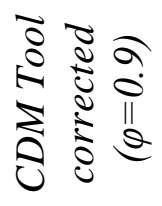 & 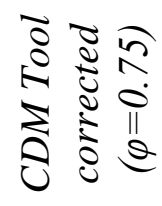 \\
\hline & & $\mathrm{A}$ & $\mathrm{B}$ & $\mathrm{C}$ & $\mathrm{D}$ & $\mathrm{E}$ & $\mathrm{F}$ & $\mathrm{G}$ \\
\hline \multirow{3}{*}{ Adrianópolis } & Max & $21 \%$ & $27 \%$ & $32 \%$ & $30 \%$ & $34 \%$ & $38 \%$ & $45 \%$ \\
\hline & Min & $12 \%$ & $14 \%$ & $18 \%$ & $19 \%$ & $21 \%$ & $23 \%$ & $28 \%$ \\
\hline & $A v g$ & $16 \%$ & $20 \%$ & $25 \%$ & $24 \%$ & $28 \%$ & $31 \%$ & $37 \%$ \\
\hline \multirow{3}{*}{ Bandeirantes } & Max & $47 \%$ & $46 \%$ & $43 \%$ & $64 \%$ & $52 \%$ & $58 \%$ & $69 \%$ \\
\hline & Min & $25 \%$ & $23 \%$ & $28 \%$ & $51 \%$ & $41 \%$ & $45 \%$ & $54 \%$ \\
\hline & $A v g$ & $33 \%$ & $31 \%$ & $33 \%$ & $57 \%$ & $47 \%$ & $52 \%$ & $62 \%$ \\
\hline \multirow{3}{*}{ ESTRE's Paulínia } & Max & $43 \%$ & $51 \%$ & $63 \%$ & $71 \%$ & $78 \%$ & $87 \%$ & $104 \%$ \\
\hline & Min & $28 \%$ & $36 \%$ & $43 \%$ & $41 \%$ & $52 \%$ & $57 \%$ & $69 \%$ \\
\hline & $A v g$ & $35 \%$ & $43 \%$ & $53 \%$ & $56 \%$ & $64 \%$ & $71 \%$ & $85 \%$ \\
\hline \multirow{3}{*}{ Caieiras } & $\operatorname{Max}$ & $64 \%$ & $84 \%$ & $105 \%$ & $87 \%$ & $106 \%$ & $117 \%$ & $141 \%$ \\
\hline & Min & $32 \%$ & $56 \%$ & $69 \%$ & $40 \%$ & $70 \%$ & $78 \%$ & $93 \%$ \\
\hline & $A v g$ & $52 \%$ & $69 \%$ & $87 \%$ & $67 \%$ & $89 \%$ & $99 \%$ & $119 \%$ \\
\hline
\end{tabular}

It also worth noting that for Adrianópolis in Table 6, it was used a methane fraction in biogas of $39.74 \%$, according to PDD-2 and based in past measurements. As the usual value is about 50\% (Themelis and Ulloa, 2007; IPCC, 2006), this could be an indication that the negative pressure for extraction could be excessive leading to dilution of the biogas with outside air, lowering the $\mathrm{CH}_{4}$ ratio to $\mathrm{CO}_{2}($ Bingermer and Crutzen, 1987). Scharff and Jacobs (2006) also indicate that the extraction system can lower the methane concentration and reduce it from the default value of $55 \%$. Moreover, IPCC (2006) guidelines note that the fraction of methane in generated landfill gas should not be confused with measured methane in the gas emitted from SWDS, because $\mathrm{CO}_{2}$ is absorbed in seepage water, which would lead to a higher methane fraction. If $50 \%$ were used instead of $40 \%$, the efficiencies for Adrianópolis would be even lower in inverted proportion.

On the other hand, Caieiras has very high results. As it can be observed, default waste fractions from IPCC (2006) were adopted for it, differently from Bandeirantes, a neighbor landfill, both serving the São Paulo municipality. The food fraction - the fastest degrading one - is $44.9 \%$ in the first case and $60.6 \%$ in the second. Another difference is that Caieiras was considered to be in a temperatewet condition but Bandeirantes is said to be in a tropical-wet condition: they are in a threshold situation that has consequences in the decay constants. If the same Bandeirantes' parameters were used for Caieiras, its maximum efficiency - 
considering the CDM Tool with corrections but without uncertainty factor - drops from $106 \%$ to $64 \%$, which seems more reasonable.

Table 7. Differences from the used models to the ones without the intrinsic errors

\begin{tabular}{lcc}
\hline \multicolumn{1}{c}{ Landfill } & First crediting period & Second crediting period \\
& $P D D-1$ & $P D D-2$ \\
\hline Adrianópolis & $30 \%$ & $3 \%$ \\
Bandeirantes & $1 \%$ & $-13 \%$ \\
ESTRE's Paulínia & $23 \%$ & $-6 \%$ \\
Caieiras & $28 \%$ & $7 \%$ \\
\hline
\end{tabular}

Environmental characterization is important and may be changed. Emissions from landfills - along with waste stabilization - can be enhanced and accelerated so as to occur significantly more rapidly, as indicated by US-EPA (2005-b), if the landfill is designed and operated as a bioreactor, primarily involving moisture addition or leachate recirculation. US-EPA (2005-a) indicates default values for model parameters considering American conventional landfills (not in arid areas), a decay constant $k$ of $0.04 \mathrm{yr}^{-1}$ and a methane generation potential $L_{0}$ of $100 \mathrm{~m}^{3} \mathrm{CH}_{4} / \mathrm{t}$ waste, but if they are operated as bioreactors the values $0.7 \mathrm{yr}^{-1}$ and $96 \mathrm{~m}^{3} \mathrm{CH}_{4} / \mathrm{t}$ waste apply respectively. Even knowing that US-EPA (2005-b) suggests the conservative value for $k$ of $0.3 \mathrm{yr}^{-1}$ for wet landfills, this still means that a faster rate of gas production is achieved with this technology.

In the case of Bandeirantes, information in its monitoring reports emphasize that the difference between forecast and monitored result was mainly due to the poor final cover layer, which increases the gas leakage through the landfill's surface. This can partially explain the relatively low extraction efficiencies.

The results of this thesis are presented in Table 7 in another way: the differences to the PDD values if methane generation were calculated with the corrections indicated here, for each 7-year crediting period. The models used in the PDDs led to a significant overestimation in methane generation, from $23 \%$ to $30 \%$, for the first crediting period in three cases - those recently started, and to an underestimation for the second crediting period in two of them - the ones with operation finished or about to finish.

Another source of uncertainty when considering a biogas generation model is the proper annual amount of waste to be disposed of. From 2003 to 2012, the annual differences from the first PDDs to the second ones were high in three of them. In Adrianópolis, the average increase was $72 \%(\min 24 \%$, max 168\%); Bandeirantes: average increase of $3 \%$ (min $-14 \%$, max 11\%); ESTRE's Paulínia: average increase of $106 \%$ (min $22 \%$, max 180\%); Caieiras average increase of $66 \%$ (min 3\%, max 136\%). Nevertheless, the actual amounts were taken into account here for the comparison among the models, thus eliminating this kind of uncertainty.

\section{CONCLUSIONS}

When the Kyoto Protocol entered into force in 2005, or even earlier, as Brazilian entrepreneurs became aware of its imminence, it became a driving force to transform uncontrolled SWDS into landfills associated with the capture and destruction of methane. This took place in Brazil as well as in the developing world. 
Having the incentive of obtaining carbon credits, entrepreneurs made investments in projects that could solve environmental problems; and, when the credits were sold, the economic equation would be completed.

In the recent years, in addition to the drop in carbon-credit prices, the results demonstrated in this thesis show that the CDM projects face difficulties in predicting methane generation. Although partially solved with improved models, there are still uncertainties in these models, such as in establishing values for the decay constants that depend on local climatic conditions; and, there are also uncertainties on the composition and amount of waste annually disposed of. In this regard, additional research is necessary in order to look further into the local reality. This thesis also recommends the CDM Executive Board to correct its methodological tool to calculate emissions from solid waste disposal sites, as its use yields a significant overestimation in the forecasted amount of methane generation in new landfills and an underestimation in landfills closing their operation, as demonstrated in this study.

In view of a Brazilian law, which enforces the end of uncontrolled solid waste disposal sites, the use of improved models to predict methane generation is very important in order to allow a correct understanding of how this greenhouse gas can be used as a clean energy source in lieu of being irresponsibly released into the atmosphere.

\section{REFERENCES}

Bingemer, H. G. and Crutzen, P. J. The production of methane from solid wastes. Journal of Geophysical Research, Vol. 92, 1987. NO. D2: 2181-2187. 7p.

CDM - Clean Development Mechanism (Kyoto Protocol). Information on rules, methodologies, tools, and project activities are available at the link: http://cdm.unfccc.int/, accessed from January 2014 to May 2014.

IPCC. Revised 1996 IPCC Guidelines for National Greenhouse Gas Inventories: Volumes 1, 2 and 3. Houghton, J.T., Meira Filho, L.G., Lim, B., Tréanton, K., Mamaty, I., Bonduki, Y., Griggs, D.J. and Callander, B.A. (Eds). Intergovernmental Panel on Climate Change (IPCC), IPCC/OECD/IEA, Paris, France, 1997.

IPCC. Good Practice Guidance and Uncertainty Management in National Greenhouse Gas Inventories. Penman, J., Kruger, D., Galbally, I., Hiraishi, T., Nyenzi, B., Enmanuel, S., Buendia, L., Hoppaus, R., Martinsen, T., Meijer, J., Miwa, K. and Tanabe, K. (Eds). Intergovernmental Panel on Climate Change (IPCC), IPCC/OECD/IEA/IGES, Hayama, Japan, 2000.

IPCC. 2006 IPCC Guidelines for National Greenhouse Gas Inventories. Prepared by the National Greenhouse Gas Inventories Programme, Eggleston H.S., Buendia L., Miwa K., Ngara T. and Tanabe K. (eds). Published: IGES, Japan, 2006.

Kyoto Protocol, 1997. Link: http://unfccc.int/resource/docs/convkp/kpeng.pdf, accessed January 2014.

Oonk, H. Literature Review: methane from landfills - methods to quantify generation, oxidation and emission. OonKAY! Innovations in Environmental Technology, The Netherlands, 2010. 
Personal communication, received at < mauro.meirelles.mct@gmail.com> on $16 / 10 / 2014$.

Scharff, H. and Jacobs, J. Applying guidance for methane emission estimation for landfills. Waste Management 26, 2006: 417-429. 13 p.

Themelis, N. J., Ulloa, P. A. Methane generation in landfills. Earth Engineering Center and Department of Earth and Environmental Engineering, Columbia University, New York, NY 10027, USA. Renewable Energy 32, 2007: 12431257. $15 \mathrm{p}$.

UNFCCC. COP Decision 17/CP.8 - Annex, paragraph 11, 2002a. Link: http://unfccc.int/resource/docs/cop8/07a02.pdf\#page $=2$

COP Decision 18/CP.8 - Annex, paragraphs 9 and 10, 2002b. Decision's link: http://unfccc.int/resource/docs/cop8/07a02.pdf\#page=13; annex's link: http://unfccc.int/resource/docs/cop8/08.pdf

Methodological Tool - Emissions from solid waste disposal sites, 2012. Link: http://cdm.unfccc.int/methodologies/PAmethodologies/tools/am-tool-04v6.0.1.pdf., version 06.0.1

COP Decision 24/CP.19 - Annex I, paragraphs 3, 9, and 10, 2013. Link: http://unfccc.int/resource/docs/2013/cop19/eng/10a03.pdf\#page=2

US-EPA. Landfill Gas Emissions Model (LandGEM) Version 3.02 User's Guide, United States, 2005a. EPA-600/R-05/047.

First-Order Kinetic Gas Generation Model Parameters for Wet Landfills. United States, 2005b. EPA-600/R-05/072.

Van Elk, A. G. H. P. Redução de emissões na disposição final. Coordination Karin Segala - Rio de Janeiro: IBAM. Brazil, 2007. (in Portuguese)

World Bank. Handbook for the Preparation of Landfill Gas to Energy Projects in Latin America and the Caribbean. Prepared by Conestoga-Rovers \& Associates, 2004. Ref. No 019399 (6).

\section{Keywords}

Landfills; biogas generation; models; CDM; Clean Development Mechanism. 


\section{Sumário}

$\begin{array}{ll}\text { Resumo } & 6\end{array}$

$\begin{array}{ll}\text { Expanded Abstract } & 7\end{array}$

Listas de abreviaturas e símbolos $\quad 35$

1. Introdução 37

1.1 O problema 37

1.2 Objetivos (final e intermediários) 41

1.3 Relevância do estudo $\quad 41$

1.4 Delimitação do estudo 43

1.5 Literatura consultada 44

1.5 Organização desta dissertação 46

2. Metodologia para análise dos projetos MDL e dos modelos de geração de metano relacionados 48

2.1 Análise dos modelos de geração de metano 51

2.2 Análise dos projetos MDL 51

2.3 Resultados e discussão 53

2.4 Limitações do método 53

3. Análise dos modelos de geração de metano 54

3.1 O modelo do IPCC (1997) 57

3.2 O modelo do IPCC (2000) 59

3.3 O modelo CDM Tool 65

3.3.1 Proposta de correção para o modelo CDM Tool 68

3.4 O modelo IPCC (2006) 68

3.5 O modelo Scholl-Canyon $\quad 70$

3.6 O modelo LandGEM Versão $3.02 \quad 70$

3.7 Utilização desses modelos / diferenças nos resultados 71

4. Projetos MDL analisados $\quad 78$

4.1 Informações dos projetos a partir de seus PDDs 78 
4.1.1 Projeto de Aproveitamento do Biogás de Aterro

Sanitário - NovaGerar

4.1.2 Projeto Bandeirantes de Gás de Aterro e Geração de Energia

4.1.3 Projeto de Recuperação de Gás de Aterro ESTRE Paulínia

4.1.4 Redução de emissões de gás de aterro de Caieiras 83

4.2 Análise dos relatórios de monitoramento 85

4.2.1 NovaGerar 85

4.2.2 Bandeirantes 89

4.2.3 ESTRE-Paulínia 91

4.2.4 Caieiras 92

5. Resultados e discussão 96

6. Conclusões e sugestões 108

Referências bibliográficas 


\section{Lista de Figuras}

Figura 1: llustração do desenvolvimento da composição do gás e do lixiviado numa célula de um aterro (Christensen e Kjeldsen, 1989)

Figura 2 - Erro introduzido pela não integração completa da taxa da curva da reação, com o entendimento de que as emissões são calculadas a partir do ano após a disposição (IPCC, 2006)

Figura 3 - Erro introduzido com o entendimento de que as emissões são calculadas desde o ano de disposição (interpretação do autor) 59 Figura 4 - Efeito do erro na equação do IPCC (2000) - eq. (9) (IPCC, 2006)

Figura 5 - Exemplificação do uso correto do modelo IPCC (2000)

Figura 6 - Comparação dos modelos da ferramenta do MDL: atual e modificado para o caso de simulação

Figura 7 - Geração total de metano segundo o modelo da ferramenta do MDL atual comparada com a da ferramenta corrigida, para projetos com um período de crédito de 7 anos, segundo cada possível ano inicial, para o mesmo caso de simulação da Figura 676

Figura 8 - Eficiências de extração para cada modelo - Adrianópolis 99

Figura 9 - Eficiências de extração para cada modelo - Bandeirantes 100 Figura 10 - Eficiências de extração para cada modelo - ESTRE-

\section{Paulínia} 100

Figura 11 - Eficiências de extração para cada modelo - Caieiras 101

Figura 12 - Variação da geração de metano, apenas considerando-se a correção no CDM Tool, tendo em vista a disposição de resíduos, além do resultado do monitoramento - Adrianópolis.

Figura 13 - Variação da geração de metano, apenas considerando-se a correção no CDM Tool, tendo em vista a disposição de resíduos, além do resultado do monitoramento - Bandeirantes.

Figura 14 - Variação da geração de metano, apenas considerando-se a correção no CDM Tool, tendo em vista a disposição de resíduos, além do resultado do monitoramento - ESTRE-Paulínia.104 
Figura 15 - Variação da geração de metano, apenas considerando-se a correção no CDM Tool, tendo em vista a disposição de resíduos, além do resultado do monitoramento - Caieiras. 


\section{Lista de Tabelas}

Tabela 1 - Parâmetros usados nos modelos $\quad 72$

Tabela 2 - Caso de simulação: emissões calculadas pelos modelos discutidos neste documento

Tabela 3 - Disposição de resíduos em Adrianópolis, segundo o $P D D-1$ e o $P D D-2$

Tabela 4 - Disposição de resíduos em Bandeirantes, segundo o $P D D-1$ e o $P D D-2$

Tabela 5 - Disposição de resíduos em ESTRE-Paulínia, segundo o $P D D$-1, o $P D D$-1_Rev e o $P D D-2$

Tabela 6 - Disposição de resíduos em Caieiras, segundo o $P D D-1$, $P D D$-1_Rev e $P D D-2$

Tabela 7 - Dados de oxidação de metano por mês, em $\mathrm{CO}_{2} e$, para

NovaGerar

86

Tabela 8 - Cálculo do ajuste para completar o ano de 2007

Tabela 9 - Quantidade de metano captado, ou oxidado, no projeto NovaGerar por ano

Tabela 10 - Dados de reduções na linha de base por período, em $\mathrm{CO}_{2} \mathrm{e}$, para Bandeirantes

Tabela 11 - Cálculo do metano captado, ou oxidado, no Projeto Bandeirantes por ano

Tabela 12 - Dados de reduções na linha de base por período, em $\mathrm{CO}_{22}$, para ESTRE-Paulínia

Tabela 13 - Cálculo do metano captado, ou oxidado, no Projeto ESTRE-Paulínia por ano

Tabela 14 - Dados de reduções na linha de base por período, em $\mathrm{CO}_{2} \mathrm{e}$, para Caieiras

Tabela 15 - Constante de decaimento e potencial de metano usados nos primeiros $P D D \mathrm{~s}$

Tabela 16 - Frações de resíduos utilizadas nos segundos $P D D$ s

Tabela 17 - Informações gerais dos aterros estudados (dos PDDs e relatórios de monitoramento) 
Tabela 18 - Eficiências de extração (valores máximo, mínimo e médios, dentro do período de observação) para cada aterro considerado e modelo

Tabela 19 - Diferenças entre os modelos usados e os modelos sem os erros intrínsecos 


\section{Listas de abreviaturas e símbolos}

A - fator de normalização que corrige o somatório no modelo do IPCC (2000)

CDM - Clean Development Mechanism (em português, MDL)

CDM Tool-Methodological Tool - Emissions from solid waste disposal

sites - Version 06.0.1 (UNFCCC, 2011) (Ferramenta metodológica do MDL

- Emissões da disposição de resíduos sólidos - versão 06.0.1)

CER - Certified Emission Reduction (em português, RCE)

$\mathrm{CH}_{4}-$ metano

$\mathrm{CO}_{2}$ - dióxido de carbono

$\mathrm{CO}_{2} \mathrm{e}$ - dióxido de carbono equivalente

COD - Carbono Orgânico Degradável (em inglês, DOC)

COP - Conference of Parts (Conferência das Partes)

DCP - Documento de Concepção de Projeto (em inglês, PDD)

DOC - Degradable Organic Carbon (em português, COD)

$\mathrm{DOC}_{\mathrm{F}}$ - fração do carbono orgânico degradável que realmente se decompõe

DOE - Designated Operational Entity (em português, EOD)

DPO - Decaimento de Primeira Ordem (em inglês, FOD)

EOD - Entidade Operacional Designada (em inglês, DOE)

$\mathrm{F}$ - fração em volume de $\mathrm{CH}_{4}$ no gás de aterro

FOD - First Order Decay (em português, DPO)

GEE - Gás de Efeito Estufa (em inglês, $G H G$ )

$\mathrm{Gg}-10^{9}$ gramas ou 1.000 toneladas

GHG - Greenhouse Gas (em português, GEE)

GWP - Global Warming Potential (Potencial de Aquecimento Global)

IPCC - Intergovernmental Panel on Climate Change (Painel

Intergovernamental sobre Mudança do Clima)

$\mathrm{k}$ - constante de decaimento (ou de reação)

$\mathrm{k}_{\mathrm{j}}$ - constante de decaimento para o resíduo de tipo $j$

$\mathrm{L}_{0}$ - potencial de geração de metano

LandGEM - Landfill Gas Emissions Model

LDRS - Locais de Disposição de Resíduos Sólidos (em inglês, SWDS) 
$\mathrm{m}^{3}-$ metro cúbico

$\mathrm{MCF}$ - fator de correção do metano

MDL - Mecanismo de Desenvolvimento Limpo (em inglês, $C D M$ )

$\mathrm{Mg}-10^{6}$ gramas ou 1 tonelada

MMA - Ministério do Meio Ambiente

MSW - Municipal Solid Waste (em português, RSU)

$\mathrm{N}_{2} \mathrm{O}$ - óxido nitroso

OMM - Organização Meteorológica Mundial (em inglês, WMO)

ONU - Organização das Nações Unidas

OX - fator de oxidação de metano na camada de cobertura do aterro

PDD - Project Design Document (em português, DCP)

PNUMA - Programa das Nações Unidas para o Meio Ambiente (em inglês, UNEP)

RCE - Redução Certificada de Emissão (em inglês, $P D D$ )

Rio-92 - Conferência das Nações Unidas sobre o Meio Ambiente e o Desenvolvimento, ocorrida em 1992

RSU - Resíduos sólidos urbanos (em inglês, $M S W$ )

SWDS - Solid Waste Disposal Sites (em português, LDRS)

UNEP - United Nations Environmental Program (em português, PNUMA)

UNFCCC - United Nations Framework Convention on Climate Change

(Convenção-Quadro das Nações Unidas sobre Mudança do Clima)

US-EPA - United States Environmental Protection Agency

$\mathrm{t}$ - tonelada

t 1⁄2 - tempo de meia-vida do carbono degradável dos resíduos

WMO - World Meteorological Organization (em português, OMM)

$\eta$ - eficiência de extração (metano capturado em relação ao metano gerado no aterro)

$\varphi$ - Fator de correção para levar em conta as incertezas do modelo CDM Tool

Obs: Variáveis utilizadas apenas no âmbito da definição dos modelos não estão indicadas aqui. 


\section{Introdução}

\subsection{O problema}

Em 1992, numa reunião ocorrida na cidade do Rio de Janeiro, a Conferência das Nações Unidas sobre o Meio Ambiente e o Desenvolvimento - conhecida também como Rio-92 - as nações do mundo reconheceram que as atividades humanas estavam aumentando as concentrações de gases responsáveis pelo efeito estufa na atmosfera e intensificando o fenômeno do aquecimento global. Os países concordaram em trabalhar para uma solução, nascendo ali a Convenção-Quadro das Nações Unidas sobre Mudança do Clima (em inglês, United Nations Framework Convention on Climate Change - UNFCCC), ou Convenção do Clima, com o objetivo fundamental de tentar reverter o processo.

$\mathrm{O}$ efeito estufa acontece naturalmente na atmosfera, evitando que a Terra tenha uma temperatura média cerca de $30^{\circ} \mathrm{C}$ menor sem ele. Mas a vida como a conhecemos depende desse equilíbrio de temperatura. A intensificação do efeito estufa é consequência do aumento da concentração dos gases dióxido de carbono $\left(\mathrm{CO}_{2}\right)$, metano $\left(\mathrm{CH}_{4}\right)$ e óxido nitroso $\left(\mathrm{N}_{2} \mathrm{O}\right)$, principalmente, e que têm sido emitidos de forma acelerada desde a revolução industrial. O uso dos combustíveis fósseis - carvão e petróleo - levam o carbono estocado durante milhões de anos para a atmosfera. Aliado a outros processos causados pelo homem, como o desflorestamento, a criação de animais, a indústria, a agricultura em larga escala, tudo isso está trazendo desequilíbrio para o sistema climático. Há graves consequências previstas, como aumento do nível do mar, intensificação de eventos extremos, como secas, inundações, furacões, além da mudança no padrão de temperaturas. Tais alterações afetariam não só a produção de alimentos quanto a distribuição de vetores de diversas doenças.

O quadro é extremamente preocupante, conforme indicam os relatórios periódicos do Painel Intergovernamental de Mudança do Clima - IPCC - que reúne os estudos dos maiores especialistas mundiais sobre o assunto. A responsabilidade humana sobre o aquecimento global é enfatizada de forma crescente a cada novo relatório. 
A cada ano a Convenção do Clima reúne todos os países, nas chamadas Conferências das Partes - COPs - para acertar detalhes da implementação das ações necessárias para o combate ao aquecimento global. Numa delas, a de 1997 em Quioto, no Japão, foi criado o chamado Protocolo de Quioto (Kyoto Protocol, 1997), com o estabelecimento de metas de redução de gases de efeito estufa para os países industrializados. Esses países são os que devem tomar a liderança da redução de gases de efeito estufa, segundo um dos princípios fundamentais da Convenção do Clima, o das responsabilidades comuns porém diferenciadas. Mas o Protocolo de Quioto também criou mecanismos para facilitar o atingimento de tais metas.

Um deles, o Mecanismo de Desenvolvimento Limpo - MDL - objetiva também auxiliar os países em desenvolvimento a usarem práticas e tecnologias mais eficientes e capazes de reduzir as emissões de gases de efeito estufa em diversos tipos de projetos. Essas reduções seriam transformadas em "créditos de carbono" que poderiam ser utilizados pelos países industrializados no cumprimento de suas metas em troca da tecnologia usada, dos recursos necessários para a implementação desses projetos, ou numa combinação de ambas as coisas.

Desde 2005, quando entrou finalmente em vigor o Protocolo de Quioto, 369 projetos brasileiros de MDL já foram registrados ${ }^{13}$, cobrindo diversos setores de atividades. Todos os projetos MDL precisam obedecer rigorosamente diretrizes e metodologias aprovadas previamente, seja diretamente pelas COPs, seja pelo Conselho Executivo do MDL, já que seus resultados, os créditos de carbono, precisam de credibilidade internacional para serem usados pelos países industrializados em suas obrigações legais de redução.

Um dos tipos de projeto MDL muito comuns é o de queima do metano gerado em aterros sanitários. O metano constitui cerca de 50\% do gás proveniente da decomposição anaeróbica dos resíduos orgânicos de um aterro, gás esse chamado genericamente de biogás. Segundo o IPCC (2001), cerca de três a quatro por cento das emissões antropogênicas globais de gases de efeito estufa devem-se a esse tipo de emissões.

Segundo o primeiro Inventário Brasileiro de Gases de Efeito Estufa, que cobriu os anos de 1990 a 1994 (Brasil, 2006), a disposição dos resíduos sólidos no

${ }^{13}$ Conforme informação do site da Convenção do Clima, acessado em 23/11/2014, no endereço http://cdm.unfccc.int/Projects/projsearch.html. 
país dividia-se entre $76 \%$ em lixões a céu aberto, $22 \%$ em aterros controlados e sanitários e $2 \%$ em outras destinações. Não havia até então maiores preocupações com o metano que emanava para atmosfera, a não ser manter uma chama em alguns drenos no chão dos aterros para queimar o gás e evitar riscos de explosão pelo seu acúmulo, já que o metano não é tóxico, é inodoro, embora comburente e potencialmente explosivo. É preciso que se diga que os lixões têm geração de biogás menor do que os aterros, já que não possuem a mesma condição anaeróbica ausência de oxigênio - que caracteriza os últimos.

Com o MDL, abriu-se a oportunidade para, ao lado de se melhorar as condições sanitárias da disposição dos resíduos sólidos urbanos, através da construção de aterros sanitários em substituição a lixões, captar e oxidar o gás de efeito estufa a ser emitido em maior quantidade - o que geraria créditos de carbono a serem transformados em recursos financeiros que viabilizariam os empreendimentos. Tal oxidação poderia ser a simples queima eficiente do metano, quanto seu uso para a geração de energia elétrica, com redução adicional de gases de efeito estufa pela redução do uso de termelétricas do sistema interligado nacional. A oportunidade foi aproveitada pelos empresários no Brasil, o primeiro a registrar um projeto MDL no mundo ${ }^{14}$, justamente desse tipo, o NovaGerar, Projeto de Energia a partir de Gases de Aterro Sanitário, situado em Nova Iguaçu, no Estado do Rio de Janeiro (será visto no item 4.2.1).

Registre-se que existem outras soluções em que se evita a geração do metano nos aterros sanitários e que já podem ser projetos MDL: evitando-se a disposição de resíduos orgânicos no aterro, como sua queima de resíduos para energia ou sua compostagem para adubo, ou fazendo-se uma aeração passiva ou ativa do aterro. Soluções para a oxidação do metano por conta de uma camada especial de recobrimento do aterro, com uso de bactérias metanotróficas, ainda são objeto de estudos (Bahr et al., 2006; Teixeira et al., 2007), mas ainda não têm uma metodologia aprovada pelo Conselho Executivo do MDL.

Ao se pensar em fazer um projeto MDL de redução de emissões de aterro sanitário é importante prever a quantidade de gás a ser gerada durante a vida útil desse aterro. Uma das dificuldades para se fazer um projeto MDL é demonstrar que ele só seria feito a partir da perspectiva dos ganhos a serem gerados pelos seus

${ }^{14}$ Ver a ordem dos projetos MDL em http://cdm.unfccc.int/Projects/projsearch.html, com os campos de pesquisa em branco. 
créditos de carbono vendidos aos países industrializados. É a chamada regra da adicionalidade que todo projeto MDL tem que respeitar. $\mathrm{O}$ objetivo dessa regra do Protocolo de Quioto foi justamente o de fazer acontecer projetos que, caso não fossem registrados como MDL, não ocorreriam. Projetos que ocorreriam de qualquer forma não podem ter créditos de carbono, pois isso apenas significaria maiores emissões nos países industrializados, sem contrapartida extra nos países em desenvolvimento e comprometendo a integridade ambiental do Protocolo de Quioto.

Portanto, o quanto o projeto vai gerar de biogás, ou de metano, o quanto vai receber em troca dos créditos de carbono pela eliminação desse metano, será importante para o equacionamento financeiro do projeto, para sua viabilidade econômica e para seu registro como MDL.

No Brasil, os aterros sanitários iniciaram as atividades de captação e queima do biogás em flares motivados pelo incremento financeiro advindo do MDL (ICLEI, 2009), o que se confirmava também pela análise dos projetos MDL brasileiros, onde se explicitava que, antes do MDL, não havia interesse em investir recursos para a queima do gás metano (von Randow et al., 2009). Embora seja necessário para os projetos de aterro sanitário sob MDL, saber com antecedência quanto um aterro vai gerar de emissões é importante também nos países industrializados, para quantificação do potencial energético do efluente gasoso ou simplesmente para a contabilização em seus inventários nacionais de gases de efeito estufa.

Em resumo, a questão que se quer aqui discutir, já que os aterros sanitários atuais preveem a captação e o uso do biogás, é:

As eventuais discrepâncias entre a previsão de geração e a captação efetiva de biogás dos aterros sanitários operados sob o MDL podem ser explicadas pelo uso inadequado dos modelos de previsão?

Esse é o problema que a presente dissertação procura discutir. 


\subsection{Objetivos (final e intermediários)}

O objetivo final dessa dissertação é verificar até que ponto os modelos matemáticos utilizados para a previsão do metano a ser gerado pelos aterros sanitários escolhidos para este estudo representam a sua realidade observada, ao longo dos anos do projeto.

Para que o objetivo final possa ser atingido, alguns objetivos intermediários foram definidos:

1. Mostrar que o portal do $\mathrm{MDL}^{15}$ deve ser usado como fonte de informação importante para pesquisas aplicadas sobre técnicas e processos.

2. Verificar quais aterros sanitários registrados como MDL têm uma sequência de dados de monitoramento suficientemente longa para permitir análises confiáveis, para serem selecionados para o estudo.

3. Comparar o resultado prático de captação do metano com o previsto no modelo original.

4. Comparar o resultado com outros modelos disponíveis na literatura e possíveis de serem aplicados com os dados disponíveis.

\subsection{Relevância do estudo}

A experiência acumulada pelos projetos MDL de aterros sanitários no Brasil permite já uma sedimentação do conhecimento no setor. O presente estudo, que visa o melhor entendimento da forma de se calcular a geração do metano dos aterros, poderá ser usado para facilitar a criação de novos projetos de aproveitamento do biogás, o que até agora só tem acontecido no país sob o incentivo do MDL do Protocolo de Quioto, mas que não lhe é exclusivo.

O MDL poderia ser visto como um ganho nulo em relação à atmosfera, já que uma quantidade de gás de efeito estufa é reduzida num país em desenvolvimento para permitir a mesma quantidade ser emitida num país desenvolvido, quando o ciclo do mecanismo de flexibilização se completa. Há, porém, uma outra possibilidade de uso dos créditos de carbono, onde há ganho ambiental efetivo, surgida em 13 de setembro de 2012, por decisão da $69^{\text {a }}$ reunião do Conselho

\footnotetext{
${ }^{15}$ Endereço: http://cdm.unfccc.int/.
} 
Executivo do MDL: a neutralização de emissões de diversos eventos. Os créditos podem ser cancelados a pedido de seus proprietários, seja através de pagamento por empresa ou pessoa física que assim o deseje, seja através de ações gratuitas mas que tenham benefícios de visibilidade, impedindo assim seu uso inicialmente previsto. Exemplo do primeiro tipo aconteceu na Rio+20, quando foram pela primeira vez foram oferecidos créditos de carbono para venda àqueles que quisessem neutralizar suas emissões. Para o segundo caso, tem-se a oportunidade de doação de créditos de carbono para neutralização das emissões da Copa do Mundo de 2014, tendo a empresa doadora, a título de contrapartida, o direito de utilizar o Selo Sustentabilidade "Baixo Carbono", regido pela Portaria MMA n 70/2014 (Brasil, 2014) e ter seu nome veiculado nos relatórios de gestão e resultados do Ministério do Meio Ambiente.

Mas o principal objetivo do MDL, a longo prazo, é a internação de novas e mais eficientes tecnologias para aproveitamento energético de todas as fontes renováveis possíveis e uma trajetória menos emissora de gases de efeito estufa no caminho para o desenvolvimento de um país. Hoje, empresários e governos já percebem o desperdício de energia se aterros forem construídos sem aproveitamento do biogás gerado, em projetos para se eliminar a prática insalubre de lixões. Em breve chegará o tempo em que o incentivo do MDL não será mais necessário para isso, quando as tecnologias passarem a ser prática comum, o que levará à perda da necessária condição de adicionalidade desses projetos.

É preciso esclarecer que o outro constituinte importante do biogás é o $\mathrm{CO}_{2}$, que também é eliminado para a atmosfera, mas não representa problema para o aquecimento global, por ser de origem biológica, ou seja, faz parte do ciclo normal da vida, que emite $\mathrm{CO}_{2}$ para a atmosfera e posteriormente o retira através fotossíntese dos vegetais. Já o $\mathrm{CH}_{4}$ é produto da ação humana - pelo fato, no caso, de acumularmos resíduos num local - com impacto no aquecimento global, de forma 21 vezes mais intensa do que o $\mathrm{CO}_{2}$ de origem fóssil. No entanto, ao ser queimado, é convertido em $\mathrm{CO}_{2}$ de mesma origem biológica, portanto sem maiores malefícios. Por isso também que o uso do metano proveniente de decomposição anaeróbica de resíduos orgânicos é um combustível dito renovável, e gera energia renovável.

O tema também encerra uma necessidade atual em vista da Lei $\mathrm{N}^{\mathrm{o}} 12.305$, de 2 de agosto de 2010, que institui a Política Nacional de Resíduos Sólidos (Brasil, 
2010), onde se institui um prazo de quatro anos, para a eliminação de lixões no país, conforme seu artigo 54, embora a Política Nacional de Meio Ambiente, (Lei 6.938/1981, Art. 10) e a Lei de Crimes Ambientais (Lei 9.605/1998, Art. 54, §2º V) já houvessem tentado fazê-lo. Como o aproveitamento energético é estimulado, o conhecimento prático do processo de geração do metano torna-se importante.

Quando se pensa no uso do biogás para geração de energia elétrica, deve-se ter em mente que, nesse caso, há um investimento maior do que simplesmente o necessário para um queimador (flare) de metano. Para um aterro fechado, a quantidade de metano gerado é decrescente, o que vai gerar a necessidade de um estudo de investimentos, já que depois de um certo tempo, os geradores podem ir sendo desativados ou transferidos para outros lugares. Em outras palavras, o pleno aproveitamento energético logo após o encerramento da disposição de resíduos precisa ser confrontado com o momento em que se deve desativar cada gerador (normalmente são utilizados vários geradores). Por isso a importância de se prever as quantidades anuais de geração de metano pelo aterro e não simplesmente a quantidade total emitida pelo aterro, ao longo de todo o processo (muitos anos além do encerramento do aterro).

\subsection{Delimitação do estudo}

O presente estudo se ateve apenas aos projetos brasileiros de aterros sanitários registrados como atividades de projeto MDL. Todo o trabalho irá se basear nos relatórios oficiais e públicos que caracterizam todo o processo do MDL.

No Brasil, em janeiro de 2014, havia 49 atividades de projeto de aterro registrados no site do MDL, sendo um deles pertencente a um Programa de Atividades, uma modalidade de MDL que visa a facilitar o registro de atividades de projeto semelhantes e que usem uma mesma metodologia. Este trabalho se restringiu à análise dos projetos que foram submetidos a uma renovação do seu primeiro período de crédito de sete anos, dentro dos procedimentos do MDL, quando é necessário atualizar a metodologia de linha de base e de monitoramento, bem como o histórico do aterro. Isto porque, no estudo prévio feito para este trabalho, observou-se que tais projetos renovados apresentavam uma grande variação nas quantidades anuais de resíduo efetivamente recebidas. Assim fazendo, 
elimina-se uma das fontes de incerteza dos modelos de geração. Apenas quatro projetos de MDL no Brasil se enquadravam nesta condição em maio de 2014.

Note-se que uma atividade de projeto MDL pode escolher entre um período de sete anos para o primeiro período de crédito, com possibilidade de renovação por mais dois períodos de sete anos ou um período de dez anos sem renovação. Por isso, não foram escolhidos aterros que optaram por períodos de crédito não renováveis.

Sendo assim, os projetos MDL selecionados para a pesquisa são os seguintes:

- Projeto NovaGerar - Projeto de Energia a partir de Gases de Aterro Sanitário - Ref. 0008

- Projeto Bandeirantes de gás de Aterro e Geração de Energia em São Paulo, Brasil - Ref. 0164

- Projeto de Recuperação de Gás de Aterro ESTRE - Paulínia (PROGAE) - Ref. 0165

- Projeto de Redução de Emissões de Biogás, Caieiras - Brasil - Ref. 0171

Os números de referência são dados pelo registro do MDL, que numera as atividades de projeto independentemente dos seus tipos.

\subsection{Literatura consultada}

A literatura básica para este trabalho provém dos guias metodológicos para inventários nacionais de gases de efeito estufa do Painel Intergovernamental de Mudança do Clima - IPCC. Esse organismo internacional foi criado, em 1988, pelo Programa das Nações Unidas para o Meio Ambiente - UNEP - e pela Organização Meteorológica Mundial - WMO - para reunir as evidências científicas sobre o aquecimento global devido ao aumento da concentração dos gases de efeito estufa. Seu trabalho provocou a convocação da Rio-92 pela ONU. É o IPCC que estabeleceu as diretrizes, adotadas pela Convenção do Clima, para a contabilização dos gases de efeito estufa pelos países.

Há três publicações nesse sentido relacionadas às emissões de gases de efeito estufa pela disposição de resíduos sólidos: "Revised 1996 IPCC Guidelines for 
National Greenhouse Gas Inventories", publicado em 1997, "Good Practice Guidance and Uncertainty Management in National Greenhouse Gas Inventories", publicado em 2000, e "2006 IPCC Guidelines for National Greenhouse Gas Inventories", publicado em 2006. Essas publicações oferecem um refinamento cada vez maior para se estimar as emissões de metano pelos aterros sanitários. Porém, para uso em inventários nacionais, seu uso precisa ser aprovado pela Convenção do Clima, em uma COP. Em relação às diretrizes do IPCC (2006), apenas na COP-19, realizada em novembro de 2013, em Varsóvia, é que seu uso foi tornado obrigatório para os países desenvolvidos nas suas submissões a partir de 2015 à UNFCCC. Isso não impede seu uso para outras finalidades, como por exemplo nos projetos MDL.

Há que se notar também que os projetos MDL precisam se basear em metodologias específicas e normas aprovadas pelo Conselho Executivo, de modo a permitir a verificação das condições definidas pelo Protocolo de Quioto ${ }^{16}$. Tais metodologias levam em conta não só as diretrizes do IPCC como também certas particularidades, como descontos devido a práticas anteriores à elaboração do projeto, transformação de unidades para equivalentes de $\mathrm{CO}_{2}$, entre outras. As metodologias têm atualização frequente, para seu contínuo aperfeiçoamento. Depois de alguns anos após os primeiros projetos, foi disponibilizada uma ferramenta de cálculo para se determinar as emissões de um aterro sanitário. Assim sendo, no presente trabalho as metodologias do MDL e suas ferramentas metodológicas precisam também ser levadas em conta para interpretação dos dados disponíveis.

A partir das diretrizes do IPCC, suas referências da literatura usada também oferecem uma visão mais detalhada do assunto, servindo de ponto de partida para novas pesquisas bibliográficas. Há também outras fontes de referência que devem ser consultadas, já que se referem a modelos de previsão específicos importantes, com vários pontos de superposição com os do IPCC: o Banco Mundial produziu um manual para exploração de gás de aterro para América Latina e Caribe (World Bank, 2004) e cita o modelo Scholl-Canyon, bem como o produzido pela agência ambiental americana, que conta com uma versão renovada (US EPA, 2005-a).

16 O Artigo 12.5 define tais condições: (a) Participação voluntária aprovada por cada Parte envolvida; (b) Benefícios reais, mensuráveis e de longo prazo relacionados com a mitigação da mudança do clima, e (c) Reduções de emissões que sejam adicionais às que ocorreriam na ausência da atividade certificada de projeto. 
Vários artigos sobre o assunto foram consultados: Bingemer e Crutzen (1987), citados pelo IPCC, analisam a produção mundial de metano pelos aterros sanitários; Scharff e Jacobs (2006) comparam seis diferentes modelos para três aterros holandeses; Themelis e Ulloa (2006) estudam aterros americanos. Esses estudos dão informações importantes sobre a formação do biogás e concentrações de metano.

Outra publicação consultada foi Oonk (2010), um dos autores da seção de disposição de resíduos sólidos do IPCC (2006) e com estudo já referenciado no IPCC (2000), em que faz uma revisão de literatura, apresentando métodos para quantificar a geração, oxidação e emissão de metano dos aterros.

Do Brasil, foi consultada a publicação de Alves e Cardoso $F^{o}$ (2002), sendo Alves também um dos autores da seção de disposição de resíduos sólidos do IPCC (2006), além da publicação de van Elk (2007).

Para facilidade de referência e leitura dos documentos publicados no site do MDL, alguns termos, abreviaturas e expressões estão mantidos em sua forma em inglês e grafados no estilo itálico. A lista de abreviaturas também apresenta as correspondências em português, quando isso for significativo.

\subsection{Organização desta dissertação}

Além deste capítulo de Introdução, este trabalho desenvolve-se nos seguintes outros capítulos:

- Cap. 2 - Metodologia para análise dos projetos MDL e dos modelos de geração de metano relacionados, onde se detalha as formas de abordagem do objeto do estudo;

- Cap. 3 - Análise dos modelos de geração de metano, onde se entra em detalhes nos diversos modelos escolhidos para o estudo, na interpretação corrente de seus parâmetros e nas diferenças em suas estimativas;

- Cap. 4 - Projetos MDL analisados, onde são apresentadas as atividades de projeto MDL que fizeram parte deste trabalho, suas características e seus dados de operação;

- Cap. 5 - Resultados e discussão, onde se faz uma análise dos resultados obtidos; 
- Cap. 6 - Conclusões e sugestões, onde se conclui o trabalho e se apresentam pistas para a sua continuidade;

- Referências bibliográficas.

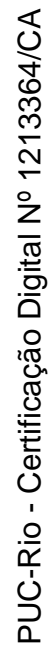




\section{Metodologia para análise dos projetos MDL e dos modelos de geração de metano relacionados}

Para se avaliar um modelo matemático de previsão é preciso usar seus resultados, obtidos a partir de certos dados de entrada, com resultados reais alcançados. Então, uma abordagem possível seria a medição direta dos gases emanados de um aterro, através de diversos métodos. Oonk (2010) indica vários deles: medições de amostras do solo retiradas de diversas profundidades da cobertura, que dão informações sobre os processos de difusão e oxidação; medições usando câmaras fechadas; medições micrometeorológicas sobre um plano acima do aterro; medições através de seções / balanços de massa; medições através da pluma de um gás traçador; medições da pluma do metano; medições qualitativas de emissões. Todas elas têm vantagens e desvantagens e podem ser combinadas, mas requerem muito trabalho de campo e recursos.

Outra abordagem seria usar as quantidades recuperadas de metano, como o que se pretende neste trabalho, baseando-se nos dados obtidos com a estrutura do MDL. Conforme Oonk (2010), a quantidade de geração de metano pode ser obtida conhecendo-se a eficiência da extração $(\eta)$ e a quantidade capturada ${ }^{17}$ :

$$
\text { geração de metano }=\text { metano capturado } / \eta
$$

Mas, a seguir, ele afirma que há dois pré-requisitos para essa abordagem: em primeiro lugar, a quantidade recuperada tem que ser limitada pela geração e não pela possibilidade de uso do metano (por exemplo, capacidade limitada de sua queima); em segundo lugar, a recuperação do gás de aterro tem que usar o estadoda-arte, significando número suficiente de poços (quando poços verticais são usados, num mínimo de dois hectares), recuperação também nas partes não fechadas do aterro, controles e ajustes bissemanais da pressão de sucção nos poços.

No caso dos projetos MDL envolvendo gás de aterro, o ponto importante é o de captar e oxidar o máximo de metano possível, pois essa quantidade vai ser traduzida em créditos de carbono e, a seguir, vendida para os países desenvolvidos

\footnotetext{
${ }^{17}$ Esta equação está agora em sua forma correta (Oonk, 2014).
} 
interessados ou usada pelos países investidores, o que significa realizar a expectativa de recursos/créditos que foi determinante para a decisão de se fazer o projeto. Um projeto pode simplesmente queimar o metano sem geração de energia, usá-lo para acionar geradores elétricos ou uma combinação das duas situações. Mas nos casos em que se prevê o uso de geradores, haverá sempre um queimador pronto para ser acionado em caso de atraso na instalação dos mesmos ou de sua parada para manutenção. Os projetos MDL também usam o estado-da-arte na sua concepção, sendo muitas vezes organizados por companhias estrangeiras, como aliás prevê o Protocolo de Quioto. É sempre oportuno lembrar que, por trás do comércio de créditos de carbono, existe a intenção de se difundir as melhores tecnologias para os países em desenvolvimento atingirem um desenvolvimento sustentável. Assim, ficam verificados os pré-requisitos exigidos por Oonk (2010) para se usar aqui as quantidades recuperadas de metano para confronto com os modelos de geração. A eq. (1) será ligeiramente modificada para estimar, para cada modelo $i$ de previsão, a eficiência da atividade de projeto, através do uso das quantidades de metano capturadas:

$\eta_{\text {Modelo } i}=$ metano capturado $/$ geração de metano Modelo $i$

Uma vez que os modelos matemáticos podem usar diferentes parâmetros, produzindo diferentes estimativas, a eficiência da atividade de projeto deve ser avaliada de acordo com cada conjunto modelo/parâmetros, o que pode ser feito de forma independente, ano após ano, e, em seguida, comparada com a planejada eficiência do projeto.

Como os créditos de carbonos gerados pelos projetos MDL irão servir para o atingimento de metas de redução de outros países, através de acordo internacional legalmente vinculante, todo cuidado é tomado durante todo o processo para garantir a integridade do mecanismo. Um projeto só poderá usar metodologia aprovada pelo Conselho Executivo do MDL, que possui um Painel Metodológico como suporte científico; essa metodologia descreve minuciosamente as condições de sua utilização e os passos a serem seguidos, até mesmo de frequência de manutenção dos instrumentos de medição; o cumprimento da metodologia, a partir da concepção do projeto, deverá ser validado por uma Entidade Operacional Designada - EOD que é previamente autorizada pelo Conselho Executivo para atuar nessa função; 
durante a operação do projeto, uma outra EOD será necessária para verificar e aprovar os relatórios de monitoramento que serão emitidos ao longo da sua vida. Em casos de projetos de pequena escala, o que não tem sido o caso dos aterros sanitários, a mesma EOD poderá ser utilizada.

Outro aspecto importante de um projeto MDL é que o documento de concepção de projeto ( $P D D$, em inglês) deve ser transparente o suficiente para permitir ao leitor a reprodução dos cálculos e verificação das hipóteses assumidas ${ }^{18}$. Isso será usado nesta dissertação, para se refazer os cálculos das previsões de geração de metano no $P D D$ e conferir o uso do modelo usado, já que deve haver uma expectativa expressa para as reduções de emissões para os sete ou dez anos iniciais do projeto, conforme opção dos seus proponentes ${ }^{19}$. O fato de um $P D D$ ser apresentado de forma padronizada, já que seguem modelos específicos, facilita sua análise.

Da mesma forma, os relatórios de monitoramento são colocados publicamente no portal do MDL, de modo que se pode acompanhar o andamento do projeto no que se refere à geração de créditos e tudo o que está envolvido nesse processo. Os relatórios de monitoramento, feitos pelos operadores do projeto, são verificados, como foi dito acima, por uma EOD, que pode fazer outras considerações sobre os resultados, para poder gerar o relatório de verificação e certificação das reduções, e assim gerar as Reduções Certificadas de Emissões RCE ou CER (em inglês) - vulgarmente conhecida como "crédito de carbono", e medida em toneladas de dióxido de carbono equivalente $\left(\mathrm{t} \mathrm{CO}_{2} \mathrm{e}\right)$. Cada $\mathrm{RCE}$ - cada tonelada de dióxido de carbono equivalente reduzida - tem um número único que a acompanha e possibilita seu completo rastreamento.

Então, este estudo baseia-se nos projetos MDL registrados e em funcionamento, usando seus documentos de concepção de projeto - PDDs relatórios de monitoramento periódicos, e suas alterações, caso haja. São analisadas também as informações contidas nos relatórios de monitoramento sobre diferenças em relação ao resultado previsto no $P D D$, informações essas que passaram a ser obrigatórias a partir de 2010, para maiores esclarecimentos.

\footnotetext{
${ }^{18}$ Conforme norma CDM project standard (CDM-EB65-A05-STAN), parágrafos 20 e 256, disponível no site do CDM.

${ }^{19}$ Idem, parágrafo 67.
} 
Além dos modelos de geração de biogás usados nos $P D D$ s, os demais estudados neste trabalho são também aplicados para se estudar as diferenças nos resultados, dependendo de haver informações suficientes para sua aplicação.

\subsection{Análise dos modelos de geração de metano}

Entender os diferentes modelos e conhecer as diferenças entre eles é fundamental neste trabalho. Primeiramente serão vistos os modelos de geração de metano indicados pelos guias metodológicos do $\operatorname{IPCC}(1997,2000$ e 2006) e que foram utilizados pelo Conselho Executivo MDL para definir sua própria metodologia, que deve ser utilizada pelas atividades de projeto que queiram receber os créditos de carbono. Posteriormente, serão abordados mais dois modelos também muito conhecidos, o Scholl-Canyon e o LandGEM, para ampliar a comparação.

\subsection{Análise dos projetos MDL}

\section{Informações dos projetos a partir de seus PDDs}

Os projetos serão vistos através dos seus documentos de concepção, os $P D D$ s, onde serão observados os seguintes pontos:

- Tipos de queima de metano, se via queima em flares ou para alimentação de geradores;

- Início da operação do aterro;

- Histórico ou previsão da quantidade de disposição de resíduos;

- Composição média dos resíduos;

- Modelo de previsão usado e seus respectivos parâmetros (por exemplo, potencial de geração de metano, taxa de decaimento, taxa de oxidação, fator de ajuste);

- Eficiência de extração de biogás programada;

- Eventuais etapas intermediárias de operação;

- Outras informações relevantes.

Como o foco do estudo é a geração do metano, e não a geração de créditos de carbono do projeto, serão descontados/acrescidos da previsão de créditos os referentes a:

- Geração de energia elétrica (descontar); 
- Desconto de linha de base (fator de ajuste), usado para descontar prática anterior, ou comum, de queima de metano (acrescer).

O uso, pelo projeto, de combustíveis ou eletricidade não tem sua quantidade estimada nos $P D D$ s, mas devem ser mensurados e reportados nos relatórios de monitoramento.

Para maior segurança, os cálculos de geração de metano serão refeitos e conferidos com os apresentados no $P D D$, pois a experiência do autor em análise de projetos MDL indica possibilidades de erros cometidos nesse momento. Será seguido o modelo escolhido e verificada a adequação de parâmetros passíveis de escolha. Em muitos casos, o projeto MDL apresenta uma planilha de cálculo, publicada ao lado do $P D D$; em outros, os cálculos são resumidamente apresentados no próprio arquivo do $P D D$. As eventuais divergências serão apontadas. Pelas regras do MDL, o PDD deve ser transparente, no sentido de apresentar todos os dados necessários para se conferir os cálculos.

\section{Análise dos relatórios de monitoramento}

Os relatórios de monitoramento cobrem períodos encadeados da operação do aterro, embora não haja normas quanto à duração de cada um. Todos os relatórios disponíveis devem ser utilizados, tomando-se o cuidado de identificar se há alterações solicitadas pela EOD que verificou o relatório, que aparecem no site do MDL a partir do acesso à sua história completa (full history), que sempre deve ser pesquisada para se obter a última versão aprovada.

Os relatórios de monitoramento podem ter alguma variação na apresentação dos dados: alguns mostram dados horários, enquanto outros, resultados consolidados. Resultados de medições diretas são posteriormente corrigidos pela incerteza dos instrumentos de medida, segundo fórmulas estabelecidas. Assim, apenas os resultados após o desconto devido às incertezas dos instrumentos serão utilizados nesse trabalho.

Da mesma forma que no $P D D$, cuidado será tomado para se isolar a captação de metano medida. Em casos onde ela não seja explícita, pode-se trabalhar com a quantidade de créditos gerada, com o cuidado de se descontar ou acrescer desse valor os equivalentes de $\mathrm{CO}_{2}$ referentes a:

- Uso de combustíveis (acrescer);

- Uso de eletricidade (acrescer); 
- Geração de energia elétrica (descontar);

- Desconto de linha de base (fator de ajuste), usado para descontar prática anterior, ou comum, de queima de metano (acrescer).

O uso de combustíveis e de eletricidade, a geração de energia e o desconto de linha de base são sempre explícitos.

Os valores de captação de metano, obtidos a partir da quantidade de biogás e da fração medida do metano, serão organizados por ano, que poderá ser composto por valores parciais de relatórios de monitoramento distintos. Em alguns casos, onde não haja a parte inicial do primeiro ano ou final do último ano, uma extrapolação simples poderá ser feita para completá-los.

\subsection{Resultados e discussão}

Tabelas e gráficos são organizados para a comparação entre a previsão de geração e a quantidade captada, concluindo-se por uma eficiência real de captação em relação a cada modelo apresentado, que pode ser confrontada com a expectativa da eficiência de captação de biogás, expressa nos $P D D$ s.

\subsection{Limitações do método}

Embora este trabalho esteja baseado na melhor documentação pública possível, graças às regras detalhadas do MDL e seu sistema de verificação e transparência, a realidade da geração de biogás de um aterro sanitário pode ser sempre melhor estudada, através de pesquisas de quantificação específicas, que levem em consideração as condições de temperatura e umidade do local, além do controle do material depositado e das técnicas de captação.

Os modelos teóricos baseiam-se principalmente em países estrangeiros, embora apresentem parâmetros que podem ser usados para diversas outras situações. O assunto será cada vez mais compreendido em nosso país através das pesquisas nacionais em curso, com vistas a tornar o aterro sanitário prática comum, com o melhor aproveitamento possível de suas potencialidades. 


\section{Análise dos modelos de geração de metano}

De acordo com van Elk (2007), há um complexo processo de transformação a que os resíduos sólidos depositados num aterro estão submetidos. Depois de uma rápida fase de degradação aeróbia, o ambiente perde oxigênio e os resíduos são, então, submetidos à atividade de bactérias metanogênicas, gerando metano.

Christensen e Kjeldsen (1989) identificam cinco fases para a decomposição dos resíduos sólidos em um aterro, conforme indicado na Figura 1 e definidas em seguida.
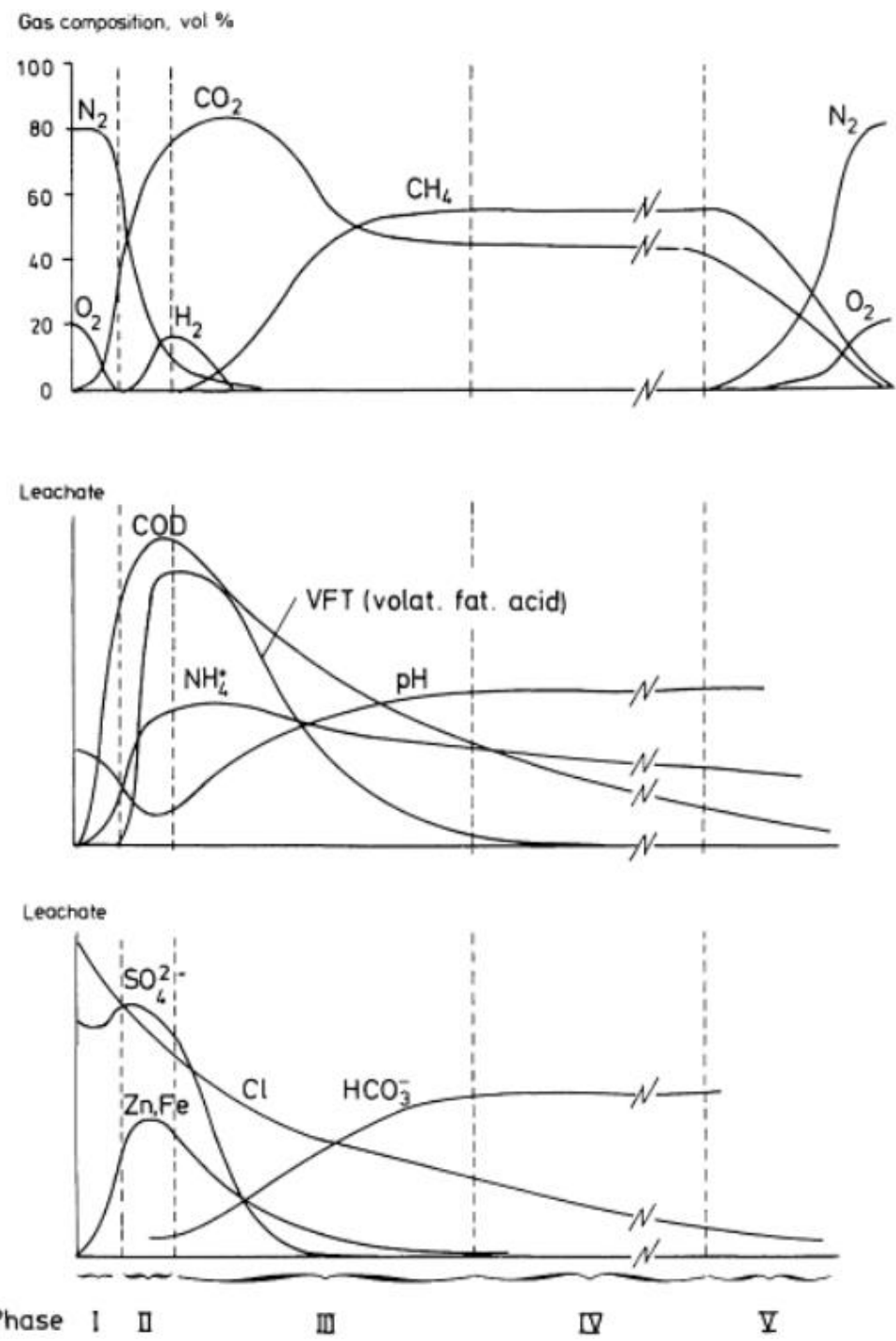

Figura 1: llustração do desenvolvimento da composição do gás e do lixiviado numa célula de um aterro (Christensen e Kjeldsen, 1989) 
Fase I: É uma fase aeróbica curta imediatamente após o depósito dos resíduos, onde a matéria orgânica facilmente degradável é decomposta aerobicamente durante a geração de dióxido de carbono.

Fase II: Uma primeira fase anaeróbica procede imediatamente após a fase aeróbica. A atividade das bactérias fermentativas e também acetogênicas resulta numa rápida geração de ácidos graxos voláteis, dióxido de carbono e algum hidrogênio. O lixiviado pode conter altas concentrações de ácidos graxos, cálcio, ferro, metais pesados e amônia, esta devido à hidrólise e fermentação de compostos proteicos, em particular. $\mathrm{O}$ conteúdo do nitrogênio no gás é reduzido devido à geração de dióxido de carbono e hidrogênio. $\mathrm{O}$ alto teor inicial de sulfato pode ser reduzido lentamente à medida que o potencial redutor cai. $\mathrm{O}$ sulfeto gerado pode precipitar o ferro, o manganês e os metais pesados que estavam dissolvidos na parte inicial desta fase.

Fase III: A segunda fase anaeróbica intermediária vai começar com lento crescimento de bactérias metanogênicas. A concentração de metano no gás aumenta, enquanto o hidrogênio, o dióxido de carbono e as concentrações de ácidos graxos voláteis diminuem. Além disso, a concentração de sulfato diminui devido à continuação da redução do sulfato. A conversão dos ácidos graxos resulta num aumento do pH (e da alcalinidade) que resulta numa diminuição da solubilidade do cálcio, do ferro, do manganês e dos metais pesados. Esses últimos são supostamente precipitados como sulfetos. Amônia está ainda sendo gerada mas não está sendo levada ao ambiente anaeróbico.

Fase IV: A fase do metano é caracterizada por uma taxa de geração de metano bem estável, que resulta numa concentração de metano no gás de 50-65\%, em volume. A elevada taxa de formação de metano mantém baixas as concentrações de ácidos graxos voláteis e hidrogênio.

Fase V: Enquanto apenas o carbono orgânico mais refratário permanece nos resíduos depositados, a taxa de geração de metano será tão baixa que o nitrogênio começará a aparecer no gás de aterro novamente devido à difusão a partir da atmosfera. Zonas aeróbicas e zonas com potencial redutor elevados demais para a formação de metano aparecerão nas camadas superiores do aterro.

Conforme afirmam os autores, não houve a preocupação de representar na Figura 1 o tempo de cada fase, apenas acrescentando que a Fase I dura apenas alguns dias e as outras, as unidades de tempo são meses, anos e décadas. Van Elk 
(2007) dá uma indicação de algumas semanas para a Fase II e de seis meses a dois anos para a Fase III. No entanto, os modelos matemáticos mais simples que tentam representar a decomposição dos resíduos depositado em um aterro tendem a ignorar essas três primeiras fases. Outros mais elaborados já incorporam um atraso, como será visto mais adiante.

O IPCC fornece diretrizes para inventários nacionais de gases de efeito estufa (GEE), incluindo as emissões de metano da disposição de resíduos sólidos. Modelos são propostos em suas três publicações IPCC (1997), IPCC (2000) e IPCC (2006). Cada publicação tem diferentes maneiras de tratar o modelo matemático chamado de Decaimento de Primeira Ordem - DPO - que considera a variação anual das emissões de metano. Esses modelos são também as raízes da metodologia utilizada para estimar as emissões de linha de base de uma atividade de projeto sobre mitigação de metano dos aterros no âmbito do MDL.

O crescimento bacteriano é exponencial, assim como a redução de matéria orgânica degradável - ou carbono orgânico degradável - refletindo no processo pelo qual esse metano é gerado para ser, ao final, emitido para a atmosfera.

Há dois parâmetros básicos para o modelo DPO: a constante $\mathrm{k}$ de decaimento (ou de reação) e o potencial de geração de metano $\mathrm{L}_{0}$. A constante k é baseada na meia-vida do carbono degradável no aterro, através da seguinte equação:

$$
\mathrm{k}=\ln (2) / \mathrm{t} 1 / 2\left(\mathrm{ano}^{-1}\right)
$$

onde $\mathrm{t} 1 \frac{1}{2}$ é a meia-vida (ano) do carbono degradável dos resíduos.

O potencial de geração de metano $L_{0}\left[\mathrm{t} \mathrm{CH}_{4} / \mathrm{t}\right.$ resíduos ou $\mathrm{m}^{3} \mathrm{CH}_{4} / \mathrm{t}$ resíduos $]$ representa a quantidade máxima de metano gerada por massa de resíduos em um tempo infinito. Esse valor é máximo em uma situação de aterro, onde os resíduos sólidos estão em condição anaeróbia, e será emitido depois de muitos anos de um decaimento exponencial. A fim de que $L_{0}$ represente o máximo de emissão por tonelada de resíduos com massa $M$, a equação para a geração de metano como função do tempo $t$ deve ser do seguinte tipo, sob condições ideais:

$$
\mathrm{Q}(\mathrm{t})=\mathrm{k} \times \mathrm{M} \times \mathrm{L}_{0} \times \mathrm{e}^{-\mathrm{kt}}
$$

Nesse caso, a quantidade total gerada será a solução da integral definida avaliada de $t=0$ a $t \rightarrow \infty$ :

$$
\begin{aligned}
\int_{0}^{\infty} Q(\mathrm{t}) d t= & {\left[-M \times L_{0} \times e^{-k t}+C\right]_{0}^{\infty}=\left[-M \times L_{0} \times e^{-\mathrm{k} . \infty}+C\right]-} \\
& {\left[-M \times L_{0} \times e^{-\mathrm{k} .0}+C\right]=M \times L_{0} }
\end{aligned}
$$


Se um modelo utilizando a abordagem de DPO puder ser reduzido ao tipo da eq. (4), então a constante $\mathrm{L}_{0}$ terá o seu significado real, o de ser o potencial de geração de metano tal como definido acima. É também uma condição de contorno: se o resultado da integral definida for do tipo $\mathrm{M} \times \alpha \times \mathrm{L}_{0}$, sendo $\alpha$ um número, o potencial de geração de metano real seria $\mathrm{L}_{0}{ }^{\prime}=\alpha \times \mathrm{L}_{0}$. Portanto, é uma maneira de verificar se uma determinada equação está correta, pelo menos em termos de emissões totais.

O modelo DPO será agora brevemente apresentado, de acordo com cada uma das publicações citadas, na ordem em que foram lançadas. Além disso, os modelos indicados em World Bank (2004) serão incluídos nesta análise. O metano recuperado e a possível fração de metano oxidado na camada de cobertura de aterro não serão aqui incluídos, já que ambos podem ser adicionados, em seu devido tempo, com o uso de medições ou valores predefinidos.

Orientação para a leitura: neste trabalho, as referências às "diretrizes IPCC” dizem respeito às considerações, análises e parâmetros contidos nas respectivas publicações; diferentemente, os "modelos do IPCC" restringem-se às equações que definem o modelo DPO, contidas nas mesmas publicações.

\subsection{O modelo do IPCC (1997)}

O modelo indicado nas diretrizes Revised 1996 IPCC Guidelines for National Greenhouse Gas Inventories (IPCC, 1997) fornece uma equação para estimar a geração de $\mathrm{CH}_{4}$ a partir de resíduos depositados em aterro em um único ano

$$
\mathrm{Q}_{\mathrm{T}, \mathrm{x}}=\mathrm{k} \times \mathrm{R}_{\mathrm{x}} \times \mathrm{L}_{0} \times \mathrm{e}^{-\mathrm{k}(\mathrm{T}-\mathrm{x})}
$$

onde:

$\mathrm{Q}_{\mathrm{T}, \mathrm{x}}=$ a quantidade de metano gerada no ano corrente $T$ pelos resíduos $R_{x}$

$\mathrm{X}=$ ano da entrada dos resíduos

$\mathrm{R}_{\mathrm{x}}=$ a quantidade de resíduos depositados no ano $x(\mathrm{Mg})$

$\mathrm{T}=$ ano em curso

$\mathrm{L}_{0}=$ potencial de geração de metano $\left(\mathrm{m}^{3} / \mathrm{Mg}\right.$ de resíduos $)$

$\mathrm{k}=$ constante de geração de metano (1/ano) 
Para essa equação, se houver disposição de resíduos no aterro no primeiro ano $(x=1)$, a emissão de metano a partir dos resíduos pode ser calculada no mesmo ano $(T=1)$. O valor gerado seria:

$$
\mathrm{Q}_{1,1}=\mathrm{k} \times \mathrm{R}_{\mathrm{x}} \times \mathrm{L}_{0} \times \mathrm{e}^{-\mathrm{k}(1-1)}=\mathrm{k} \times \mathrm{R}_{\mathrm{x}} \times \mathrm{L}_{0}
$$

Essa é também a interpretação corrente observada nos primeiros projetos de MDL de atividades que tiveram como base esta publicação: emissão começando desde o ano da disposição de resíduos.

A eq. (6) foi examinada mais tarde nas diretrizes $\operatorname{IPCC}(2006)^{20}$. O problema resulta do fato de que um evento contínuo é tratado como discreto. Ao mostrarem seus argumentos, os autores das diretrizes IPCC (2006) indicam, conforme mostrado na Figura 2, que a primeira emissão (ano $T=1)$ seria calculada a partir dos resíduos colocados no ano $0(x=0)$, utilizando-se as variáveis da eq. (6), já que a função exponencial decrescente parte do tempo zero. Assim, para o primeiro ano,

$$
\mathrm{Q}_{1,0}=\mathrm{k} \times \mathrm{R}_{\mathrm{x}} \times \mathrm{L}_{0} \times \mathrm{e}^{-\mathrm{k}(1-0)}=\mathrm{k} \times \mathrm{R}_{\mathrm{x}} \times \mathrm{L}_{0} \times \mathrm{e}^{-\mathrm{k}}
$$

Nesse caso, os pequenos triângulos pretos na Figura 1 não são contados. Para uma constante $k$ representando uma meia-vida de 10 anos, a subestimação seria de cerca de 3,5\% em comparação com os cálculos completos do balanço de massa, a área sob a curva analítica. No entanto, com a interpretação corrente, emissão desde o ano da disposição dos resíduos $(x=1)$, haveria uma superestimação, como mostrado na Figura 3.

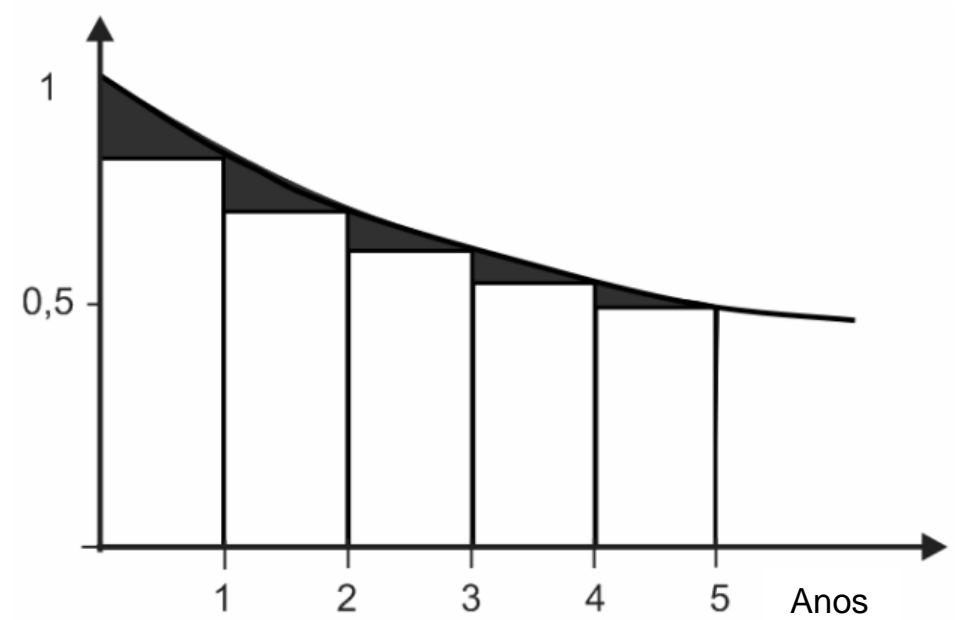

Figura 2 - Erro introduzido pela não integração completa da taxa da curva da reação, com o entendimento de que as emissões são calculadas a partir do ano após a disposição (IPCC, 2006)

\footnotetext{
${ }^{20}$ Volume 5 - Waste, Chapter 3, item 3 A1.6.1, página 3.38.
} 


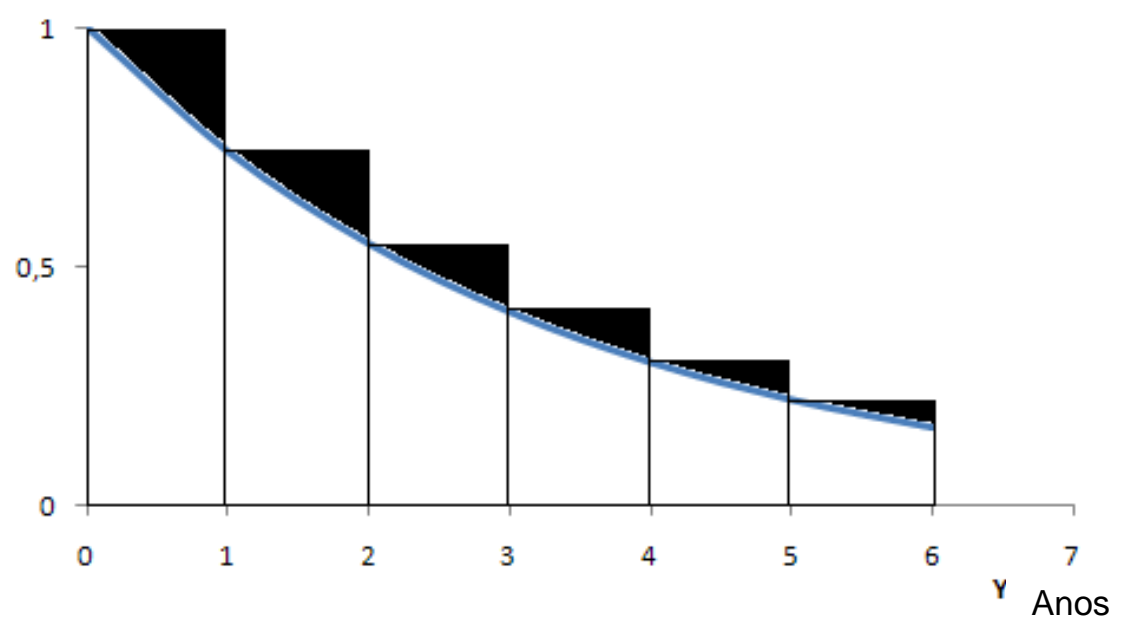

Figura 3 - Erro introduzido com o entendimento de que as emissões são calculadas desde o ano de disposição (interpretação do autor)

Aparentemente, o erro deveria apenas mudar de sinal, a diferença para o cálculo do balanço de massa completo sendo uma superestimação de cerca de 3,5\%. No entanto, além de calcular a primeira emissão com o máximo da curva, a interpretação corrente também é no sentido de se antecipar as emissões em um ano. O cálculo no ano $0(T=0)$ é feito desde o ano de disposição, ano $0(x=0)$, como se a resíduos fossem depositados nesse ano fossem emitidos desde o início desse ano, em 01 de janeiro (quando $e^{0}=1$ ). Nesse caso, a superestimação é variável em relação ao cálculo do balanço de massa completo, considerando-se a curva de emissão a partir do primeiro dia do ano seguinte. Como será mostrado mais tarde em um caso de simulação, para a mesma constante de decaimento, o aumento é de $3,8 \%$, a longo prazo, mas $23,9 \%$ em 10 anos, e 35,1\% nos primeiros 7 anos em relação ao valor indicado pela integração adequada da curva em tais períodos.

O erro aqui é importante em situações reais, especialmente se existe uma variação na quantidade de resíduos depositados nos últimos anos, ou em caso de novos aterros, como no caso de várias atividades de projeto MDL que seguiram a esta metodologia.

\subsection{O modelo do IPCC (2000)}

As diretrizes Good Practice Guidance and Uncertainty Management in National Greenhouse Gas Inventories (IPCC, 2000) propõem-se a melhorar algumas das metodologias fornecidas nas diretrizes do IPCC (1997). Para as 
emissões de locais de disposição de resíduos sólidos (LDRS), o modelo DPO ${ }^{21}$ é representado como:

$\mathrm{CH}_{4}$ gerado no ano $\mathrm{t}\left(\mathrm{Gg} . \mathrm{ano}^{-1}\right)$

$$
=\sum_{x}^{t}\left[\left(\mathrm{~A} \times \mathrm{k} \times \operatorname{MSW}_{\mathrm{T}}(\mathrm{x}) \times \operatorname{MSW}_{F}(\mathrm{x}) \times \mathrm{L}_{0}(\mathrm{x})\right) \times \mathrm{e}^{-\mathrm{k}(\mathrm{t}-\mathrm{x})}\right]
$$

onde:

$\mathrm{t}=$ ano do inventário

$\mathrm{x}=$ anos para os quais devem ser acrescentados os dados de entrada

$\mathrm{A}=\left(1-\mathrm{e}^{-\mathrm{k}}\right) / \mathrm{k}$ é um fator de normalização que corrige o somatório

$\mathrm{k}=$ constante da taxa de geração de metano (1/ano)

$\operatorname{MSW}_{\mathrm{T}}(\mathrm{x})=$ total de Resíduos Sólidos Urbanos $(\mathrm{RSU})$ gerados no ano $x(\mathrm{Gg}$ / ano)

$\operatorname{MSW}_{\mathrm{F}}(\mathrm{x})$ = Fração dos resíduos sólidos urbanos dispostos em LDRS no ano $x$

$\mathrm{L}_{0}(\mathrm{x})=$ Potencial de geração de metano $\left[\mathrm{MCF}(\mathrm{x}) \times \mathrm{DOC}(\mathrm{x}) \times \mathrm{DOC}_{\mathrm{F}} \times \mathrm{F} \times\right.$ 16 / 12 (Gg CH $4 / \mathrm{Gg}$ resíduos)]

$\operatorname{MCF}(\mathrm{x})$ = fator de correção do metano no ano $x$ (fração)

DOC $(\mathrm{x})$ = carbono orgânico degradável (COD) no ano $x$ (fração) $(\mathrm{Gg} \mathrm{C} / \mathrm{Gg}$ resíduos)

$\mathrm{DOC}_{\mathrm{F}}=$ Fração do COD que realmente se decompõe

$\mathrm{F}=$ Fração em volume de $\mathrm{CH}_{4}$ no gás de aterro

16/12 = Fator de conversão de $\mathrm{C}$ para $\mathrm{CH}_{4}$

Da mesma forma, por esta equação, a emissão de metano a partir de resíduos dispostos no aterro no ano $1(x=1)$ pode ser calculada no mesmo ano $1(t=1)$. Para comparar os modelos DPO, é muito importante calcular a primeira emissão, usando anos discretos, prestando atenção ao primeiro ano de disposição. Neste caso, seria gerada a seguinte quantidade de metano:

$\mathrm{CH}_{4}$ gerado no ano $1=\mathrm{A} \times \mathrm{k} \times \mathrm{R}_{\mathrm{x}} \times \mathrm{L}_{0} \times \mathrm{e}^{-\mathrm{k}(1-1)}=\mathrm{A} \times \mathrm{k} \times \mathrm{R}_{\mathrm{x}} \times \mathrm{L}_{0}$ onde a expressão $\mathrm{MSW}_{\mathrm{T}}(\mathrm{x}) \times \mathrm{MSW}_{\mathrm{F}}(\mathrm{x})$ da eq. (9) foi substituída por $R_{x}$, uma vez que tem o mesmo significado que o do termo correspondente na eq. (6).

${ }^{21}$ Equação 5.1, Capítulo 5, página 5.6. 
Comparando-se a eq. (10) com a eq. (6), a quantidade de metano na série anual discreta usando IPCC (1997) e IPCC (2000, respectivamente), os resultados são diferentes pelo valor do fator de normalização $A$. Não há qualquer indicação em IPCC (2000) de como este fator aparece, mas ele foi deduzido por Cassini et al. (2013) conforme descrito a seguir.

O modelo DPO é baseado na hipótese de que a geração de metano tem um decaimento exponencial, seguindo a redução de matéria orgânica degradável - ou carbono orgânico degradável. Portanto, Cassini et al. iniciaram sua dedução com a quantidade de carbono orgânico disponível $\mathrm{M}_{\mathrm{c}_{\text {disponivel }}}$ expressa como:

$$
\begin{aligned}
& \frac{\mathrm{d}\left(\mathrm{M}_{\left.\mathrm{c}_{\text {disponivel }}\right)}\right)}{\mathrm{dt}}=-\mathrm{k} \times \mathrm{M}_{\mathrm{c}_{\text {disponivel }}} \\
& \frac{\mathrm{d}\left(\mathrm{M}_{\mathrm{c}_{\text {disponivel }}}\right)}{\mathrm{M}_{\mathrm{c}_{\text {disponivel }}}}=-\mathrm{kdt} \\
& \int_{x}^{t} \frac{\mathrm{d}\left(\mathrm{M}_{\left.\mathrm{c}_{\text {disponivel }}\right)}\right)}{\mathrm{M}_{\mathrm{c} \text { disponivel }}}=\int_{x}^{t}(-\mathrm{kdt}) \\
& \left.\left.\ln M_{c_{\text {disponivel }}}\right]_{x}^{t}=-k t\right]_{x}^{t} \\
& \ln M_{c_{\text {disponivel,t }}}-\ln M_{c_{\text {disponivel, } x}}=-\mathrm{k}(t-x) \\
& \ln \frac{M c_{\text {disponivel, },}}{M c_{\text {disponivel, } x}}=-\mathrm{k}(t-x) \\
& \frac{M c_{\text {disponivel }, t}}{M c_{\text {disponível }, x}}=e^{-\mathrm{k}(t-x)} \\
& \mathrm{M}_{\mathrm{c}_{\text {disponivel, } \mathrm{t}}}=\mathrm{M}_{\mathrm{c}_{\text {disponivel }, \mathrm{x}}} \times \mathrm{e}^{-\mathrm{k}(\mathrm{t}-\mathrm{x})}
\end{aligned}
$$

onde $t$ é o ano em curso e $x$ é o ano em que os resíduos foram descartados no aterro

A quantidade de carbono orgânico que se decompõe em um ano $t\left(\mathrm{M}_{\mathrm{c}_{\text {decom,t }}}\right)$ é igual à diferença entre o carbono orgânico disponíveis para degradação no ano $t$ e o disponível para a degradação no ano $t+1$, ou:

$$
\begin{aligned}
& M_{c_{\text {decom }, \mathrm{t}}}=\mathrm{M}_{\mathrm{c}_{\text {disponivel, }}}-\mathrm{M}_{\mathrm{c}_{\text {disponivel }, \mathrm{t}+1}} \\
& \mathrm{M}_{\mathrm{c}_{\text {decom, }, \mathrm{t}}}=\mathrm{M}_{\mathrm{c}_{\text {disponivel }, \mathrm{x}}} \times \mathrm{e}^{-\mathrm{k}(\mathrm{t}-\mathrm{x})}-\mathrm{M}_{\mathrm{c}_{\text {disponivel }, \mathrm{x}}} \times \mathrm{e}^{-\mathrm{k}(\mathrm{t}+1-\mathrm{x})}
\end{aligned}
$$




$$
\mathrm{M}_{\mathrm{c}_{\text {decom }, \mathrm{t}}}=\left(1-\mathrm{e}^{-\mathrm{k}}\right) \times \mathrm{M}_{\mathrm{c}_{\text {disponivel }, \mathrm{x}}} \times \mathrm{e}^{-\mathrm{k}(\mathrm{t}-\mathrm{x})}
$$

Em seguida, o termo $\mathrm{M}_{\mathrm{c}_{\text {disponivel, } \mathrm{x}}}$ é substituído por uma combinação do carbono orgânico degradável por unidade de resíduo descartado (DOC), a fração que realmente degrada $\left(\mathrm{DOC}_{\mathrm{f}}\right)$, a própria quantidade de resíduo descartada (dependendo da quantidade de resíduos gerados pela população $\left(\mathrm{MSW}_{\mathrm{T}}(\mathrm{x})\right.$ ) e a parte que vai para o aterro sanitário $\left(\operatorname{MSW}_{\mathrm{F}}(\mathrm{x})\right)$. Por fim, a massa de carbono é convertida em metano, usando alguns termos - o fator de correção de metano (MCF) para considerar a qualidade do local, a fração de metano no biogás gerado (F) e a conversão de carbono para metano (16/12) - chegando a uma expressão que foi aqui simplificada como:

$$
\mathrm{M}_{\mathrm{CH} 4 \text { gerado,t }}=\left(1-\mathrm{e}^{-\mathrm{k}}\right) * \mathrm{R}_{\mathrm{x}} * \mathrm{~L}_{0} * \mathrm{e}^{-\mathrm{k}(\mathrm{t}-\mathrm{x})}
$$

onde:

$\mathrm{M}_{\mathrm{CH} 4 \text { gerado,t }}$ é a massa de metano gerado no ano $t$ para os resíduos depositados no ano $x$;

$\mathrm{R}_{\mathrm{x}}$ substitui a expressão $\operatorname{MSW}_{\mathrm{T}}(\mathrm{x}) \times \operatorname{MSW}_{\mathrm{F}}(\mathrm{x})$, ou seja, a quantidade de resíduo descartado;

$\mathrm{L}_{0}$ substitui a expressão $\mathrm{MCF} \times(16 / 12) \times \mathrm{F} \times \mathrm{DOC} \times \mathrm{DOC}_{\mathrm{f}}$, ou seja, o potencial de geração de metano.

A fim de chegar à forma da eq. (4), Cassini et al. introduziram a fração de $k / k$, obtendo-se assim o fator de normalização $A=\left(1-e^{-k}\right) / k$, que corrige o somatório na eq. (9). Deve ser lembrado que a emissão de metano em um determinado ano é a soma das contribuições das deposições que ocorreram em todos os anos anteriores, desde o início do aterro.

No entanto, há uma dificuldade na dedução matemática da eq. (9), como indicado nas diretrizes IPCC $(2006)^{22}$. Considerando a Figura 4, para o ano 1, como a equação é integrada do ano $t$ para o ano $t+1$, não se consegue contar a emissão de

${ }^{22}$ Volume 5 - Waste, Chapter 3, item 3 A1.6.2 página 3.38. 
metano no primeiro ano, a área marcada em preto. Para uma constante $k$ representando uma meia-vida de 10 anos, a subestimação seria de cerca de $7 \%$ em comparação à emissão calculada utilizando a integração exata da curva de decaimento.

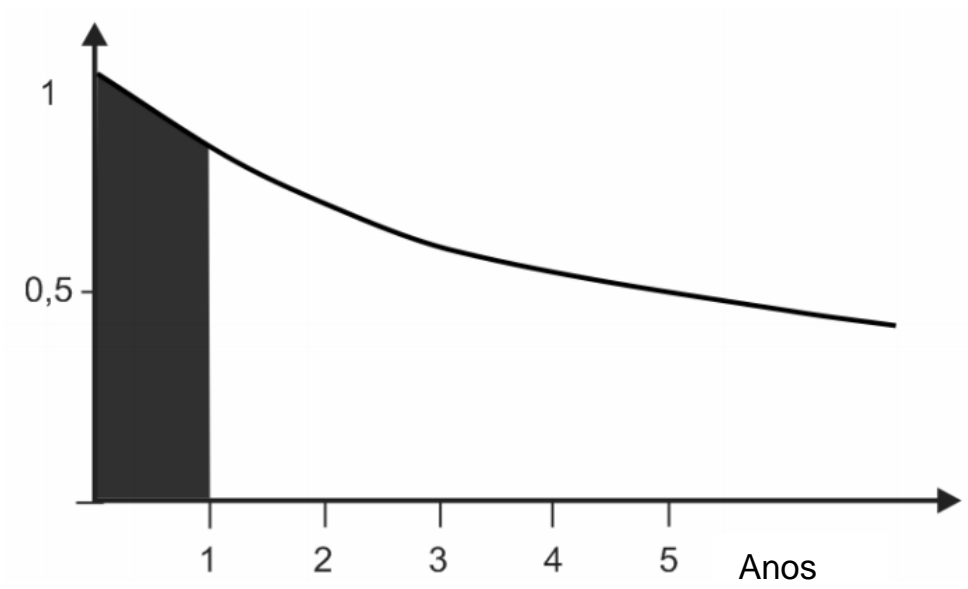

Figura 4 - Efeito do erro na equação do IPCC (2000) - eq. (9) - (IPCC, 2006)

No entanto, esse raciocínio nas diretrizes IPCC (2006) revela a interpretação de que as emissões não devem ser calculadas no primeiro ano da disposição dos resíduos, ao contrário da interpretação corrente, como observado em inventários nacionais que utilizam essa metodologia e em atividades de projeto de MDL que utilizam a mesma abordagem. Também revela que a correta interpretação da eq. (9) é que as emissões deveriam começar a ser calculadas no ano $t=2$ para os resíduos descartados durante o ano $x=1$, usando as variáveis definidas para este modelo. A variável no eixo horizontal da Figura 4 é o número de anos após a disposição dos resíduos e não o ano em que foram dispostos no aterro sanitário, no ano $x$.

As diretrizes IPCC (2006) têm a correção para o fator de normalização da eq. (9) para que a integração seja feita corretamente do ano $t$ - 1 para o ano $t$, usando a fórmula

$$
A^{\prime}=\left(\frac{1}{e^{-k}}-1\right) / k=\frac{\left(e^{k}-1\right)}{k}
$$

com o entendimento de que as emissões são sempre calculadas a partir do ano após a disposição.

Em outras palavras, uma quantidade de resíduos depositados durante o primeiro ano pode ser considerada, em média, que foi colocada no aterro de uma só vez, no meio do mesmo ano, ou seja, no dia 01 de julho. Além disso, existe um atraso típico de seis meses, não apresentado nas edições anteriores das diretrizes, 
(IPCC, 1997) e (IPCC, 2000), para o início do processo de digestão anaeróbica, o que significa que o metano começar a ocorrer em 01 de janeiro de segundo ano. Essa interpretação gera duas consequências:

1. Há um deslocamento para a direita de um ano na curva exponencial negativa das emissões;

2. Emissões que ocorrem durante o ano 2 devem ser calculadas pela integral definida do final do ano 1 ao final do ano 2 . Ou, genericamente, a partir do ano $t-1$ para o ano $t$, o ano em que a emissão deve ser calculada.

Com esses dois pontos em mente, apresenta-se aqui o modo correto de deduzir o fator de normalização que deve ser usado na eq. (9) e como interpretar as variáveis $x$ e $t$ para o cálculo das emissões anuais com base em dados discretos. A Figura 5 fornece uma imagem mais confiável do processo. O ano 1 é o ano da disposição inicial, que vai de 01 janeiro a 31 dezembro ${ }^{23}$. No ano 1 , não há emissão. A emissão começa no ano 2, e o seu valor é calculado pela integral a partir do ponto $t=1$ ao ponto $t=2 \mathrm{ou}$, genericamente, de $t-1$ a $t$, a fim de ter a emissão no ano $t$.

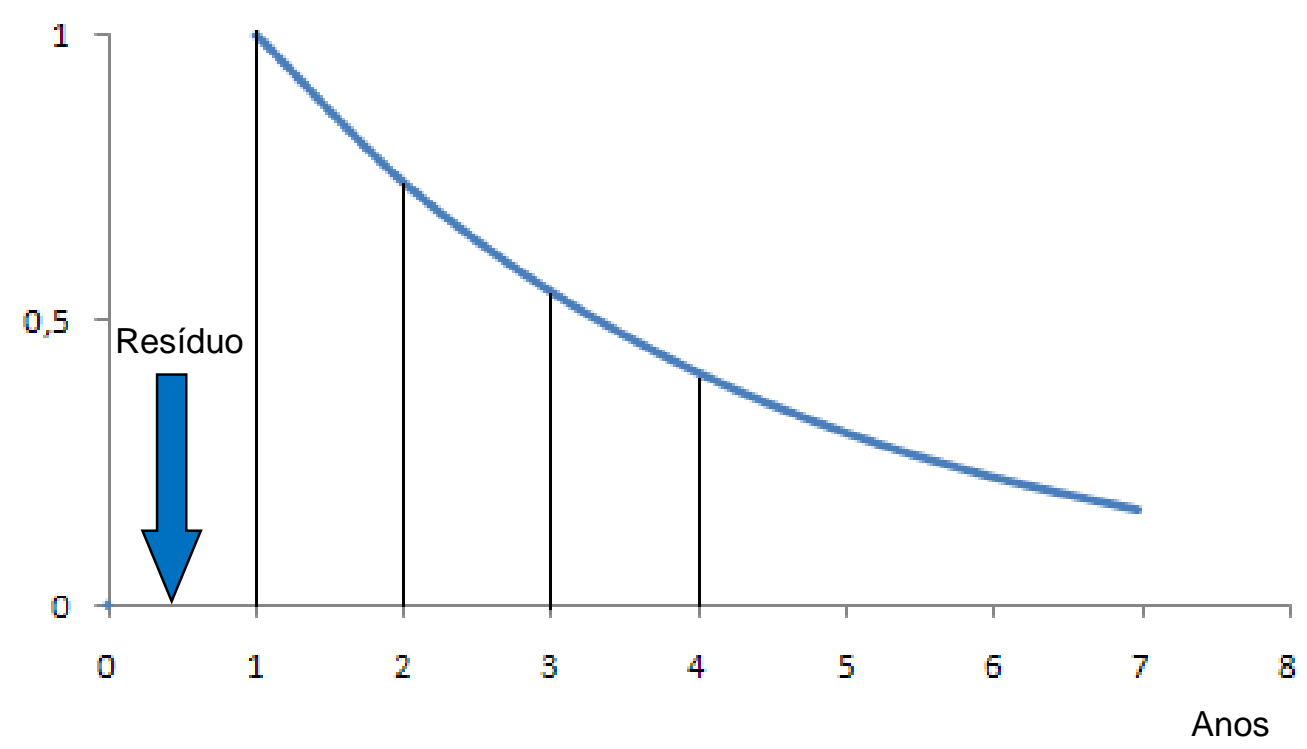

Figura 5 - Exemplificação do uso correto do modelo IPCC (2000) tempo.

${ }^{23} \mathrm{O}$ início poderia ser em qualquer outro dia do ano, com as devidas mudanças na variável 
Portanto, a dedução da eq. (12) deve ser alterada para:

$$
\begin{aligned}
& \mathrm{M}_{\mathrm{c}_{\text {decom }, \mathrm{t}}}=\mathrm{M}_{\mathrm{c}_{\text {disponivel } \mathrm{t}-1}}-\mathrm{M}_{\mathrm{c}_{\text {disponivel, } \mathrm{t}}} \\
& \mathrm{M}_{\mathrm{c}_{\text {decom }, \mathrm{t}}}=\mathrm{M}_{\mathrm{c}_{\text {disponivel }, \mathrm{x}}} \times \mathrm{e}^{-\mathrm{k}(\mathrm{t}-1-\mathrm{x})}-\mathrm{M}_{\mathrm{c}_{\text {disponivel } \mathrm{x}}} \times \mathrm{e}^{-\mathrm{k}(\mathrm{t}-\mathrm{x})} \\
& \mathrm{M}_{\mathrm{c}_{\text {decom }, \mathrm{t}}}=\left(\mathrm{e}^{\mathrm{k}}-1\right) \times \mathrm{M}_{\mathrm{c}_{\text {disponível }, \mathrm{x}}} \times \mathrm{e}^{-\mathrm{k}(\mathrm{t}-\mathrm{x})}
\end{aligned}
$$

onde $x$ é o ano da alienação e $t$ é o ano em que as emissões são calculadas (com a restrição $t \geq x+1)$, ambas sendo variáveis discretas.

Para chegar à forma de eq. (4), é apenas necessário introduzir a fração k/k para obter o novo fator de normalização $\mathrm{A}^{\prime}=\left(\mathrm{e}^{\mathrm{k}}-1\right) / \mathrm{k}$, eq. (14), como indicado em IPCC (2006) para a correção da eq. (9). Deve ser lembrado que a emissão de metano em um determinado ano corresponde à soma das contribuições de todas as quantidades de resíduos depositados em anos anteriores, desde o início do aterro.

O erro de subestimação de 7\% indicado nas diretrizes IPCC (2006) para o modelo de IPCC (2000) é válido com a interpretação de que as emissões começam no ano após a disposição. Com o entendimento corrente de que as emissões são calculadas no mesmo ano da disposição, haverá uma superestimação. Para o caso de simulação mostrado neste trabalho, apesar de haver um aumento desprezível a longo prazo (0,3\%), o aumento será de $19,7 \%$ em 10 anos e de $30,5 \%$ em 7 anos, em relação ao valor indicado pela integração adequada da curva em tais períodos. O erro aqui é também importante, especialmente se as quantidades de resíduos dispostos tiverem variado significativamente em anos anteriores ou em caso de novos aterros.

\subsection{O modelo CDM Tool}

As atividades de projeto envolvendo biogás gerado nos locais de disposição de resíduos sólidos (SWDS) e buscando registro no âmbito do MDL devem ${ }^{24}$ usar a

24 Atividades de projeto MDL precisam seguir sempre uma metodologia aprovada pelo Conselho Executivo do MDL. Para aquelas que queimam ou usam biogás de aterro, a definida é a Approved consolidated baseline and monitoring methodology ACM0001 - Flaring or use of landfill gas, disponível em http://cdm.unfccc.int/methodologies/PAmethodologies/approved, que traz em seu texto algumas normas específicas - tools ou ferramentas - para determinados pontos, e que 
norma Methodological Tool - Emissions from solid waste disposal sites - Version 06.0.1 (UNFCCC, 2011), ou simplesmente CDM Tool, para uma avaliação ex-ante da quantidade de metano, medido em equivalentes de dióxido de carbono ${ }^{25}$, usando a equação:

$$
\begin{aligned}
\mathrm{BE}_{\mathrm{CH} 4, \mathrm{SWDS}, \mathrm{y}}= & \varphi_{\mathrm{y}} \times\left(1-\mathrm{f}_{\mathrm{y}}\right) \times \mathrm{GWP}_{\mathrm{CH} 4} \times(1-\mathrm{OX}) \times \frac{16}{12} \times \mathrm{F} \times \mathrm{DOC}_{\mathrm{f}, \mathrm{y}} \\
& \times \mathrm{MCF}_{\mathrm{y}} \times \sum_{\mathrm{x}=1}^{\mathrm{y}} \sum_{\mathrm{j}} \mathrm{W}_{\mathrm{j}, \mathrm{x}} \times \mathrm{DOC}_{\mathrm{j}} \times \mathrm{e}^{-\mathrm{k}_{\mathrm{j}}(\mathrm{y}-\mathrm{x})} \times\left(1-\mathrm{e}^{-\mathrm{k}_{\mathrm{j}}}\right)
\end{aligned}
$$

onde:

$\mathrm{BE}_{\mathrm{CH} 4, \mathrm{SWDS}, \mathrm{y}}=$ Emissões de metano da linha de base que ocorrem no ano $y$ gerada a partir da disposição de resíduos sólidos em $S W D S$ durante um período que termina no ano $y\left(\mathrm{t} \mathrm{CO}_{2} \mathrm{e} / \mathrm{ano}\right)$

$\mathrm{x}=$ Anos do período em que os resíduos são depositados em SWDS, estendendo-se desde o primeiro ano no período $(x=1)$ para o ano y $(x=y)$.

$\mathrm{y}=$ Ano do período de crédito em que as emissões de metano são calculadas ( $y$ é um período consecutivo de 12 meses)

$\mathrm{DOC}_{\mathrm{f}}, \mathrm{y}=$ Fração de carbono orgânico degradável (COD) que se decompõe nas condições específicas que ocorrem nos SWDS para o ano y (fração de peso)

$\mathrm{W}_{\mathrm{j}, \mathrm{x}}=$ Quantidade de resíduos sólidos tipo $j$ depositados ou deixados de ser depositados no ano $x(\mathrm{t})$

$\varphi_{\mathrm{y}}=$ Fator de correção para levar em conta as incertezas do modelo, para o ano $y$

$f_{y}=$ Fração de metano capturada e queimada, oxidada ou utilizada de outra maneira a fim de evitar as emissões de metano para a atmosfera no ano $y$

$\mathrm{GWP}_{\mathrm{CH} 4}=$ Potencial de Aquecimento Global do metano

podem eventualmente ser referenciadas em outras metodologias, como é o caso desta ferramenta em questão.

Quando uma ferramenta é referenciadas numa metodologia, ela é necessária e obrigatória, conforme informação em http://cdm.unfccc.int/Reference/tools/index.html.

${ }^{25}$ Uma medida usada para comparar as emissões de vários gases de efeito estufa, baseada no seu Potencial de Aquecimento Global (em inglês, Global Warming Potential - GWP). Ele é calculado de acordo com as diferentes forças radiativas dos gases e seus tempos de vida na atmosfera, tendo como base um horizonte temporal definido. O valor do GWP-100 para o metano, ou seja, referente a uma comparação com o dióxido de carbono em 100 anos, foi estimado em 21, conforme indicado no Segundo Relatório de Avaliação do IPCC (1995), que é o adotado no Protocolo de Quioto até 2012. Depois desse ano, deve-se usar o novo valor de 25, conforme relatório mais recente do IPCC. 
OX = Fator de oxidação (refletindo a quantidade de metano do SWDS que é oxidada no solo ou outro material que recubra o resíduo)

$\mathrm{F}=$ Fração de metano no biogás (fração de volume)

$\mathrm{MCF}_{\mathrm{y}}=$ Fator de correção do metano para o ano $y$

$\mathrm{DOC}_{\mathrm{j}}=$ Fração de carbono orgânico degradável no tipo de resíduo $j$ (fração de peso)

$\mathrm{k}_{\mathrm{j}}=$ Taxa de decaimento para o resíduo de tipo $j$ (1/ano)

j = Tipo de resíduo depositado

A eq. (16), ou simplesmente CDM Tool (Ferramenta MDL), é usada para cálculos anuais e leva em conta as frações constituintes do resíduo, o tratamento de cada uma das frações $j$ independentemente uma das outras, com sua própria constante $k_{j}$ e potencial de geração de metano $L_{0 j}$. Ela calcula emissões em t $\mathrm{CO}_{2} \mathrm{e}$ (com o termo $G W P_{C H 4}$ ), leva em conta a parte de metano que é oxidada enquanto passa através da camada superficial do aterro (com a fração OX), e a fração que seria queimada na ausência da atividade de projeto (com a fração $f_{y}$ ). $\mathrm{O}$ fator $M C F_{y}$ é baseado na qualidade do local de disposição no ano $y$, com um valor padrão de MCF = 1 para aterros sanitários, que é o caso deste estudo comparativo.

Esta equação será aqui simplificada, com as seguintes premissas: cálculo apenas para o metano (com a remoção do termo $G W P_{C H 4}$ ); nenhum metano capturado ( $f_{y}$ igual a zero); sem oxidação pela superfície ( $O X$ igual a zero); e apenas uma única fração $j$ de resíduo contribuindo para as emissões no ano $x$ :

$$
\begin{gathered}
\mathrm{BE}_{\mathrm{CH} 4, \mathrm{SWDS}, \mathrm{y}}=\varphi_{\mathrm{y}} \times\left(1-\mathrm{e}^{-\mathrm{k}_{j}}\right) \times \mathrm{W}_{\mathrm{j}, \mathrm{x}} \times\left[\frac{16}{12} \times \mathrm{F} \times \mathrm{DOC}_{\mathrm{f}, \mathrm{y}} \times \mathrm{DOC}_{\mathrm{j}}\right] \times \\
\mathrm{e}^{-\mathrm{k}_{j}(\mathrm{y}-\mathrm{x})}
\end{gathered}
$$

O termo entre colchetes da eq. (17) é o potencial de geração de metano $L_{0}$ (com valores diferentes para cada tipo de resíduo $j$ ):

$$
\mathrm{BE}_{\mathrm{y}}=\varphi_{\mathrm{y}} \times\left(1-\mathrm{e}^{-\mathrm{k}}\right) \times \mathrm{W}_{\mathrm{x}} \times \mathrm{L}_{0} \times \mathrm{e}^{-\mathrm{k}(\mathrm{y}-\mathrm{x})}
$$

onde o fator $\varphi_{y}$ se refere às incertezas do modelo. Em uma abordagem com nenhuma incerteza para os termos $W, D O C, D O C_{f}, \mathrm{~F}, M C F_{y}$ e $\mathrm{e}^{-\mathrm{k}(\mathrm{y}-\mathrm{x})} \times\left(1-\mathrm{e}^{-\mathrm{k}}\right)$ de modo que $\varphi_{y}$ seja igual a 1, então a eq. (18) pode ser identificada com a eq. (13), a usada para verificar a metodologia de IPCC (2000) sobre o modelo DPO. Portanto, a metodologia do MDL para o cálculo das emissões de linha de base de um aterro sanitário tem o mesmo erro intrínseco do modelo IPCC (2000), apontado nas 
diretrizes IPCC (2006), conforme discutido na seção 3.2. Semelhantemente ao modelo IPCC (2000), também aqui o entendimento corrente, como observado em projetos MDL, é que as emissões são calculadas a partir do ano de disposição.

\subsubsection{Proposta de correção para o modelo CDM Tool}

A correção para o modelo do IPCC (2000), descrito na eq. (9), já foi indicada nas diretrizes IPCC (2006), com o uso do fator modificado A' - conforme indicado na eq. (14) - embora não indicando explicitamente que as emissões deveriam ser calculadas no ano após a disposição. Esta última informação pode ser encontrada em outras partes das diretrizes, com a adoção de um atraso default de seis meses para o início da reação anaeróbica.

A correção para CDM Tool, a ferramenta metodológica para atividades de projeto MDL referentes a biogás de aterro pode aqui ser proposta. Da mesma forma que a correção anterior, a eq. (16) deve ser modificada, substituindo-se o termo $\left(1-e^{-k_{j}}\right)$ por $\left(e^{k_{j}}-1\right)$, e ser calculada com a interpretação das diretrizes IPCC (2006) - emissão a partir do ano após a disposição. Assim, a eq. (16) deve ser substituída pela eq. (19), que incorpora as duas sugestões.

$$
\begin{aligned}
\mathrm{BE}_{\mathrm{CH} 4, \mathrm{SWDS}, \mathrm{y}}= & \varphi_{\mathrm{y}} *\left(1-f_{y}\right) \times G W P_{C H 4} \times(1-\mathrm{OX}) \times \frac{16}{12} \times \mathrm{F} \times \mathrm{DOC}_{\mathrm{f}, \mathrm{y}} \\
& \times M C F_{y} \times \sum_{x=1}^{y-1} \sum_{j} \mathrm{~W}_{\mathrm{j}, \mathrm{x}} \times \mathrm{DOC}_{j} * \mathrm{e}^{-k_{j}(\mathrm{y}-\mathrm{x})} *\left(\mathrm{e}^{k_{j}}-1\right)
\end{aligned}
$$

onde:

$\mathrm{y}=$ Ano do período de crédito em que as emissões de metano são calculadas (y é um período consecutivo de 12 meses), com a restrição de $\mathrm{y} \geq \mathrm{x}+1$ para explicar um atraso de seis meses para o início do processo.

\subsection{O modelo IPCC (2006)}

As orientações em 2006 IPCC Guidelines for National Greenhouse Gas Inventories (IPCC, 2006) são mais cautelosas ao tratarem um fenômeno contínuo através de valores discretos. Elas também levam em conta o atraso real observado 
na decomposição de resíduos por bactérias metanogênicas. O modelo de Decaimento de Primeira Ordem para estimar as emissões de metano dos locais de disposição de resíduos sólidos é baseado em duas equações principais:

DDOCm, a massa de COD que se degrada, acumulada nos LDRS ao final do ano $T$ :

$$
\operatorname{DDOCma}_{T}=\text { DDOCmd }_{T}+\left(\text { DDOCmd }_{T-1} \times \mathrm{e}^{-\mathrm{k}}\right)
$$

DDOCm decomposta no final do ano $T$ :

$$
\text { DDOCm decomp } \operatorname{dDDOCma}_{T-1} \times\left(1-\mathrm{e}^{-\mathrm{k}}\right)
$$

onde:

$\mathrm{T}=$ ano do inventário

$\mathrm{DDOCma}_{T}=$ DDOCm acumulado nos LDRS no final do ano $T, \mathrm{Gg}$

DDOCma $\mathrm{CH}_{T-1}=$ DDOCm acumulado nos LDRS no final do ano $(T-1), \mathrm{Gg}$

DDOCmd $_{T}=$ DDOCm depositado nos LDRS no ano $T, \mathrm{Gg}$

DDOCm decomp $p_{T}=$ DDOCm decomposto nos LDRS no ano $T, \mathrm{Gg}$

$\mathrm{k}=$ constante de reação, $k=\ln (2) / \mathrm{t}^{1} / 2\left(\mathrm{ano}^{-1}\right)$

$\mathrm{t} 1 \frac{2}{2}=$ tempo de meia-vida (anos)

A eq. (20) e a eq. (21) indicam a maneira prática para calcular o carbono que irá decompor-se em um dado ano, a partir da massa de carbono disponível no final do ano anterior.

As diretrizes do IPCC (2006) também proporcionam várias opções para determinar os valores da constante de decaimento $k$ e outros parâmetros que fazem parte do cálculo da massa de carbono degradável disponível para o processo anaeróbio, para cada tipo de fração de resíduo. Além disso, há a consideração de um atraso na decomposição dos resíduos. Um valor default de seis meses é indicado, gerando emissões somente no ano após a disposição, mas também são apresentadas soluções para atrasos menores e maiores. As diretrizes do IPCC (2006) fornecem uma planilha para integrar todos os parâmetros e informações necessárias para determinar as emissões de metano da disposição de resíduos sólidos, oferecendo como um subproduto um cálculo das quantidades de produtos de madeira colhida em geral, que ficam armazenados por longo prazo nos aterros 
sanitários, para auxiliar o balanço dos estoques de carbono necessário no sector de agricultura / florestas de um inventário nacional.

\subsection{O modelo Scholl-Canyon}

Banco Mundial (2004) apresenta o modelo Scholl-Canyon como o modelo empírico de decaimento de primeira ordem mais amplamente aceito e utilizado pela indústria e as agências reguladoras, incluindo o US-EPA. A equação de primeira ordem é definida como:

$$
Q_{C H 4 i}=k \times L_{0} \times m_{i} \times \mathrm{e}^{-\mathrm{k} t_{i}}
$$

$\mathrm{Q}_{\mathrm{CH} 4 \mathrm{i}}=$ metano produzido no ano $i$ da porção $i$ de resíduos

$\mathrm{k}=$ constante de geração de metano

$\mathrm{L}_{0}=$ potencial de geração de metano

$\mathrm{m}_{\mathrm{i}}=$ massa de resíduos descartados no ano $i$

$\mathrm{t}_{\mathrm{i}}=$ anos após o encerramento

Este modelo é muito semelhante ao do IPCC (1997), descrito pela eq. 4. Não há muito indicação sobre como a variável tempo deve ser utilizada, mas a partir da tabela que mostra os cálculos de um exemplo, pode ser visto que a quantidade de resíduos depositados em um ano iniciará a emissão de metano a partir do ano seguinte e com o máximo da função exponencial neste ano. Nesse caso, a diferença para o cálculo de massa completo é uma superestimação de cerca de 3,5\%, como explicado anteriormente na análise do modelo IPCC (1997).

No entanto, vale a pena dizer que um dos casos apresentados em Banco Mundial (2004), os aterros Marambaia-Adrianópolis - o projeto MDL NovaGerar - onde se diz usar este modelo, não usa essa abordagem, mas calcula as emissões desde o ano de disposição, como será visto neste trabalho.

\subsection{O modelo LandGEM Versão 3.02}

US-EPA (2005-a) descreve o Modelo de Emissões de Gases de Aterro (Landfill Gas Emissions Model - LandGEM) Versão 3.02. O modelo é apresentado como em uma planilha Excel que fornece valores default com base em dados empíricos de aterros dos EUA, mas permitindo outros valores. Ele pode ser usado 
tanto para a regulamentação dos Estados Unidos como para os inventários. O modelo também pode fornecer estimativas para vários poluentes, mas este trabalho se concentra apenas nos resultados de metano. A equação de primeira ordem é definida como:

$$
Q_{C H 4}=\sum_{i=1}^{n} \sum_{j=0.1}^{1} k \times L_{0} \times\left(\frac{M}{10}\right) \times \mathrm{e}^{-\mathrm{k} t_{i j}}
$$

onde:

$\mathrm{Q}_{\mathrm{CH} 4}=$ geração anual de metano no ano do cálculo ( $\left.\mathrm{m}^{3} / \mathrm{ano}\right)$

$\mathrm{i}=$ incremento de tempo de um ano

$\mathrm{n}=($ ano do cálculo $)-($ ano inicial de aceitação dos resíduos $)$

$\mathrm{j}=$ incremento de tempo de 0,1 ano

$\mathrm{k}=$ taxa de geração de metano $\left(\mathrm{ano}^{-1}\right)$

$\mathrm{L}_{0}=$ capacidade de geração de metano potencial $\left(\mathrm{m}^{3} / \mathrm{Mg}\right)$

$\mathrm{M}_{\mathrm{i}}=$ massa dos resíduos aceitos no ano $i(\mathrm{Mg})$

$\mathrm{t}_{\mathrm{ij}}=$ idade da seção $j$ da massa de resíduos $M_{i}$ aceito no ano i (anos decimais, por exemplo, 3,2 anos)

A intenção por trás deste modelo é a de tratar o processo contínuo em intervalos de tempo menores, a fim estar mais perto de uma integração correta da função de geração de metano. Como o modelo do IPCC (2006), este calcula as emissões a partir do ano após a disposição.

Considerando um aterro que receba resíduos com uma constante $k$ representando uma meia-vida de 10 anos, este modelo dá resultados com apenas $0,3 \%$ de superavaliação em relação à integração exata da curva.

\subsection{Utilização desses modelos / diferenças nos resultados}

As diretrizes do IPCC foram criadas para orientar os cálculos dos inventários de GEE nacionais, mas também são usados para aterros individuais. Países sob a UNFCCC devem usar essas diretrizes para seus inventários, embora de maneiras diferentes: os países em desenvolvimento são encorajados a usar as diretrizes IPCC $(2000)^{26}$, mas são obrigatórias para os países desenvolvidos, embora possam também usar metodologias nacionais que considerem melhor refletirem sua situação nacional, desde que essas metodologias sejam compatíveis com os

\footnotetext{
${ }^{26}$ UNFCCC, 2002a.
} 
requisitos da $\mathrm{UNFCCC}^{27}$. O uso das diretrizes IPCC (2006) será obrigatório (com as mesmas observações prévias) para os países desenvolvidos apenas para suas submissões iniciando a partir de 2015 (dados até o ano de 2013) à UNFCCC ${ }^{28}$, apesar de todos os países poderem usar a última metodologia, uma vez que julgue mais apropriado para a sua situação particular. O uso das diretrizes IPCC (1997) para as emissões de LDRS é agora menos comum.

Em relação aos projetos de MDL que lidam com biogás de aterros sanitários, a ferramenta metodológica é obrigatória para todos os casos. O modelo tem o mesmo problema discutido aqui desde a sua adoção inicial, em 2006. Essa ferramenta também é utilizada para estimar as emissões que ocorreriam quando biomassa é deixada de ser depositada em aterros, mas processada de forma aeróbica, tal como por incineração ou compostagem.

Para efeito de comparação, um caso hipotético de disposição de $100 \mathrm{mil}$ toneladas de resíduos por 20 anos em um aterro sanitário é modelado com as várias opções, para os quais os parâmetros estão mostrados na Tabela 1.

Na Tabela 1, para a opção Massa, o valor da constante de decaimento $k$ é relacionada à meia-vida de 10 anos, e o valor do potencial de geração de metano $\mathrm{L}_{0}$ foi calculado com os parâmetros da opção Frações. Para esta segunda opção, os parâmetros têm valores default das metodologias do IPCC (2006), para a América do Sul, em uma situação tropical/úmido, as mesmas consideradas no CDM Tool. Além disso, não há nenhum fator de incerteza, nenhuma oxidação na camada superior de aterro, sem oxidação de metano e perfeita condição anaeróbica.

Tabela 1 - Parâmetros usados nos modelos

\begin{tabular}{|c|c|c|c|c|c|c|c|c|}
\hline \multicolumn{2}{|c|}{ Opção } & $k$ & $L_{0}$ & $W_{j}$ & $k$ & $D O C$ & $D O C_{f}$ & Densidade do $\mathrm{CH}_{4}$ \\
\hline \multicolumn{2}{|l|}{ Massa } & 0,0693 & $\begin{array}{c}75,4 \mathrm{~m}^{3} \mathrm{CH}_{4} \\
\text { t resíduo }\end{array}$ & & & & & \multirow{5}{*}{$0,7168 \mathrm{~kg} / \mathrm{m}^{3}$} \\
\hline \multirow{4}{*}{ Frações } & Madeira & & & $4,7 \%$ & 0,035 & $43 \%$ & \multirow{4}{*}{$50 \%$} & \\
\hline & $\begin{array}{l}\text { Papel } \mathrm{e} \\
\text { papelão }\end{array}$ & & & $17,1 \%$ & 0,07 & $40 \%$ & & \\
\hline & Alimentos & & & $44,9 \%$ & 0,4 & $15 \%$ & & \\
\hline & Têxteis & & & $2,6 \%$ & 0,07 & $24 \%$ & & \\
\hline
\end{tabular}

As emissões de metano e as diferenças relativas estão mostradas na Tabela 2 para cada caso. Como essa tabela tem colunas estreitas a fim de economizar espaço, uma breve explicação poderia ajudar o leitor a identificar cada combinação referida

${ }^{27}$ UNFCCC, 2002b.

${ }^{28}$ UNFCCC, 2013. 
de modelo-opção-parâmetros-interpretação. Os modelos usando a opção Massa serão comparados com o modelo massa exato IPCC (2006) (coluna I), e os usando a opção Frações serão comparados com o modelo frações exato IPCC (2006) (coluna $\mathrm{J}$ ).

Os modelos usando a opção Massa aparecem nas primeiras colunas. A interpretação corrente para IPCC (1997) e IPCC (2000) - emissões calculadas desde o ano de disposição e com o valor máximo para a curva exponencial - estão nas colunas A e D, respectivamente. A interpretação das diretrizes IPCC (2006) para os modelos IPCC (1997) e IPCC (2000) - emissões calculadas desde o ano de disposição - estão nas colunas $\mathrm{B}$ e E, respectivamente. A interpretação das diretrizes IPCC (2006) para o modelo IPCC (1997) - emissões calculadas desde o ano após a disposição, mas com a interpretação corrente de estimar a primeira emissão com o valor máximo para a curva exponencial - está na coluna C. O modelo IPCC (2000) que usa a correção que deveria ser aplicada ao fator de normalização, com a definição pela eq. (14), e emissões calculadas a partir do ano após a disposição está na coluna F.

O modelo CDM Tool usa a opção Frações. A interpretação corrente para o modelo CDM Tool - emissões calculadas a partir do ano da disposição - está na coluna G. O modelo CDM Tool incorporando as correções propostas nesta dissertação e com emissões calculadas a partir do ano após a disposição está na coluna $\mathrm{H}$.

Vale notar neste exercício que o DOC na opção Massa é igual ao DOC combinado da opção Frações, mas existem diferentes constantes de decaimento em ambas as opções, o que leva a diferenças nos primeiros anos.

Não está apresentado na Tabela 2 o modelo Scholl-Canyon, já que apresenta duas possibilidades, conforme comentado no item 4.5: uma coincidente com o modelo "IPCC (1997) sem atraso", outra com "IPCC (1997) ACIMA atraso 6 m", ou seja, com atraso de seis meses e calculado com o máximo do valor da exponencial. 
Tabela 2 - Caso de simulação: emissões calculadas pelos modelos discutidos neste documento

\begin{tabular}{|c|c|c|c|c|c|c|c|c|c|c|c|}
\hline \multirow{4}{*}{ Indicação de tempo } & $A$ & $B$ & $C$ & $D$ & $E$ & $F$ & $G$ & $H$ & I & $J$ & $K$ \\
\hline & $\begin{array}{c}\text { IPCC } \\
\text { (1997) } \\
\text { sem atraso }\end{array}$ & $\begin{array}{c}I P C C \\
(1997) \\
A B A I X O \\
\text { atraso } 6 \mathrm{~m}\end{array}$ & $\begin{array}{c}\text { IPCC } \\
\text { (1997) } \\
\text { ACIMA } \\
\text { atraso } 6 \mathrm{~m}\end{array}$ & $\begin{array}{c}\text { IPCC } \\
(2000) \\
\text { fator } A \\
\text { sem atraso }\end{array}$ & $\begin{array}{c}I P C C \\
(2000) \\
\text { fator } A \\
\text { atraso } 6 \mathrm{~m}\end{array}$ & $\begin{array}{c}I P C C \\
(2000) \\
\text { fator } A^{\prime} \\
\text { atraso } 6 \mathrm{~m}\end{array}$ & $\begin{array}{l}\text { CDM tool } \\
\text { sem atraso }\end{array}$ & $\begin{array}{l}C D M \text { tool } \\
\text { modificado } \\
\text { atraso } 6 \mathrm{~m}\end{array}$ & \multicolumn{2}{|c|}{$\begin{array}{l}\text { IPCC (2006) } \\
\text { atraso } 6 \mathrm{~m}\end{array}$} & $\begin{array}{c}\text { LandGEM } \\
\text { Versão } \\
3.02\end{array}$ \\
\hline & Massa & Massa & Massa & Massa & Massa & Massa & Frações & Frações & Massa & Frações & Massa \\
\hline & \multicolumn{11}{|c|}{$t \mathrm{CH}_{4}$} \\
\hline Total - primeiros 7 anos & 9.199 & 6.576 & 7.048 & 8.888 & 6.353 & 6.809 & 16.158 & 12.939 & 6.809 & 12.939 & 6.833 \\
\hline Total - primeiros 10 anos & 16.977 & 13.229 & 14.179 & 16.402 & 12.781 & 13.699 & 26.727 & 23.071 & 13.699 & 23.071 & 13.746 \\
\hline Total - primeiros 60 anos & 108.269 & 100.774 & 108.007 & 104.602 & 97.361 & 104.349 & 104.213 & 104.016 & 104.349 & 104.016 & 104.711 \\
\hline Dif. primeiros 7 anos >> & $35,1 \%$ & $-3,4 \%$ & $3,5 \%$ & $30,5 \%$ & $-6,7 \%$ & $0,0 \%$ & $24,9 \%$ & $0,0 \%$ & $\begin{array}{c}\text { Modelo } \\
\text { exato }\end{array}$ & $\begin{array}{c}\text { Modelo } \\
\text { exato }\end{array}$ & $0,3 \%$ \\
\hline Dif. primeiros 10 anos >> & $23,9 \%$ & $-3,4 \%$ & $3,5 \%$ & $19,7 \%$ & $-6,7 \%$ & $0,0 \%$ & $15,8 \%$ & $0,0 \%$ & $0 \%$ & $0 \%$ & $0,3 \%$ \\
\hline Dif. primeiros 60 anos >> & $3,8 \%$ & $-3,4 \%$ & $3,5 \%$ & $0,2 \%$ & $-6,7 \%$ & $0,0 \%$ & $0,2 \%$ & $0,0 \%$ & $0 \%$ & $0 \%$ & $0,3 \%$ \\
\hline 2001 & 375 & - & - & 362 & - & - & 932 & - & - & - & - \\
\hline 2002 & 724 & 350 & 375 & 700 & 338 & 362 & 1.607 & 932 & 362 & 932 & 363 \\
\hline 2003 & 1.051 & 676 & 724 & 1.015 & 653 & 700 & 2.107 & 1.607 & 700 & 1.607 & 702 \\
\hline 2004 & 1.355 & 980 & 1.051 & 1.309 & 947 & 1.015 & 2.487 & 2.107 & 1.015 & 2.107 & 1.019 \\
\hline$\cdots$ & $\cdots$ & $\cdots$ & $\cdots$ & $\cdots$ & $\cdots$ & $\cdots$ & $\cdots$ & $\cdots$ & $\cdots$ & $\cdots$ & $\cdots$ \\
\hline 2059 & 281 & 281 & 301 & 272 & 272 & 291 & 209 & 221 & 291 & 221 & 292 \\
\hline 2060 & 262 & 262 & 281 & 253 & 253 & 272 & 198 & 209 & 272 & 209 & 273 \\
\hline
\end{tabular}


Como pode ser visto na Tabela 2 , as abordagens previstas nas diretrizes IPCC (2000) e em CDM Tool, respectivamente, para os inventários nacionais e atividades de projeto de MDL - com as correções propostas - têm o efeito de deslocar a curva de emissão para um ano depois, em comparação com os modelos sem correções. No caso de inventários, se houver períodos longos e não houver mudanças significativas nas quantidades de resíduos anualmente aterrados, a diferença final tende a ser insignificante.

Por outro lado, como os projetos MDL geralmente envolvem quantidades de resíduos que muito variam - iniciam uma série crescente ou encerram atividades de disposição - e têm curtos períodos de $\operatorname{créditos}^{29}$, as diferenças são de grande importância. A situação para um projeto MDL é mostrada na Figura 6.

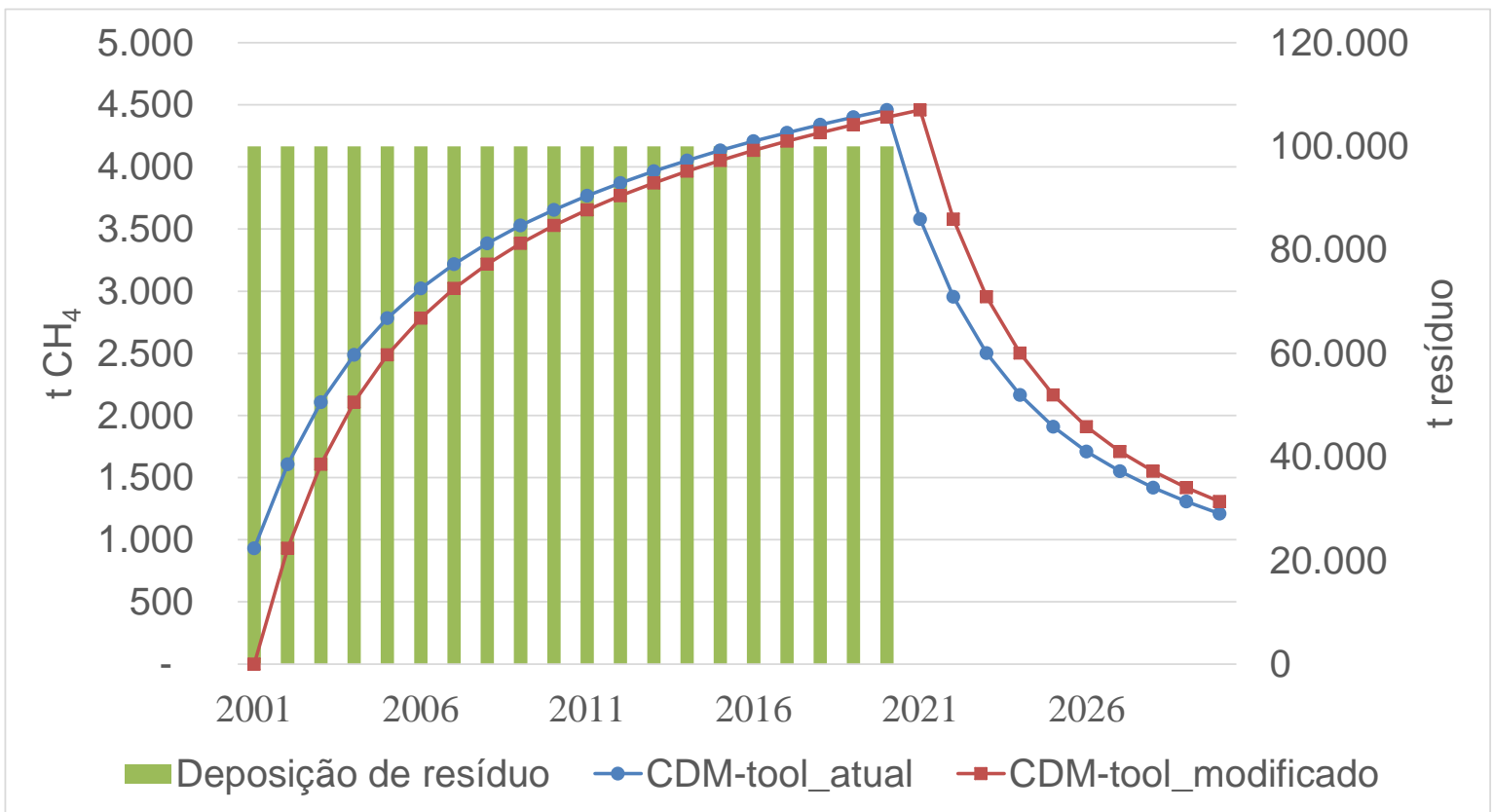

Figura 6 - Comparação dos modelos da ferramenta do MDL: atual e modificado para o caso de simulação

De acordo com os resultados apresentados na Tabela 2, num projeto que inicie um novo aterro sanitário, o modelo atual irá resultar em uma superestimação de $24,9 \%$ para os primeiros sete anos; e de $15,8 \%$ para os primeiros dez anos, em comparação com o modelo exato IPCC (2006), e que levaria a resultados abaixo do

${ }^{29}$ Uma atividade de projeto MDL pode escolher entre um período de sete anos para o primeiro período de crédito, com possibilidade de renovação por mais dois períodos iguais ou um período de dez anos sem renovação. 
esperado. Se a atividade de projeto tiver a intenção de utilizar o biogás após o encerramento do aterro, o modelo atual vai indicar uma subestimação de cerca de $10 \%$ para ambos os períodos de sete e dez anos após o encerramento, o que poderia fazer com que o projeto deixasse de ser implementado. Se o projeto MDL é sobre compostagem ou incineração, superestimação do metano evitado significa automaticamente a emissão de créditos de carbono a mais do que devido, comprometendo a integridade ambiental do Protocolo de Quioto, como se diz no jargão da comunidade que trabalha com mudanças climáticas.

O mesmo caso de simulação pode ser analisado de outra forma. Suponha que o projeto MDL selecione um determinado ano para o início de um período de crédito de sete anos. A Figura 7 mostra a diferença percentual entre a geração total de metano nesse período calculada pela ferramenta MDL atual e a calculada pela ferramenta MDL modificada, conforme a eq. (19) - mesmo resultado do modelo exato IPCC (2006) - para cada possível ano inicial.

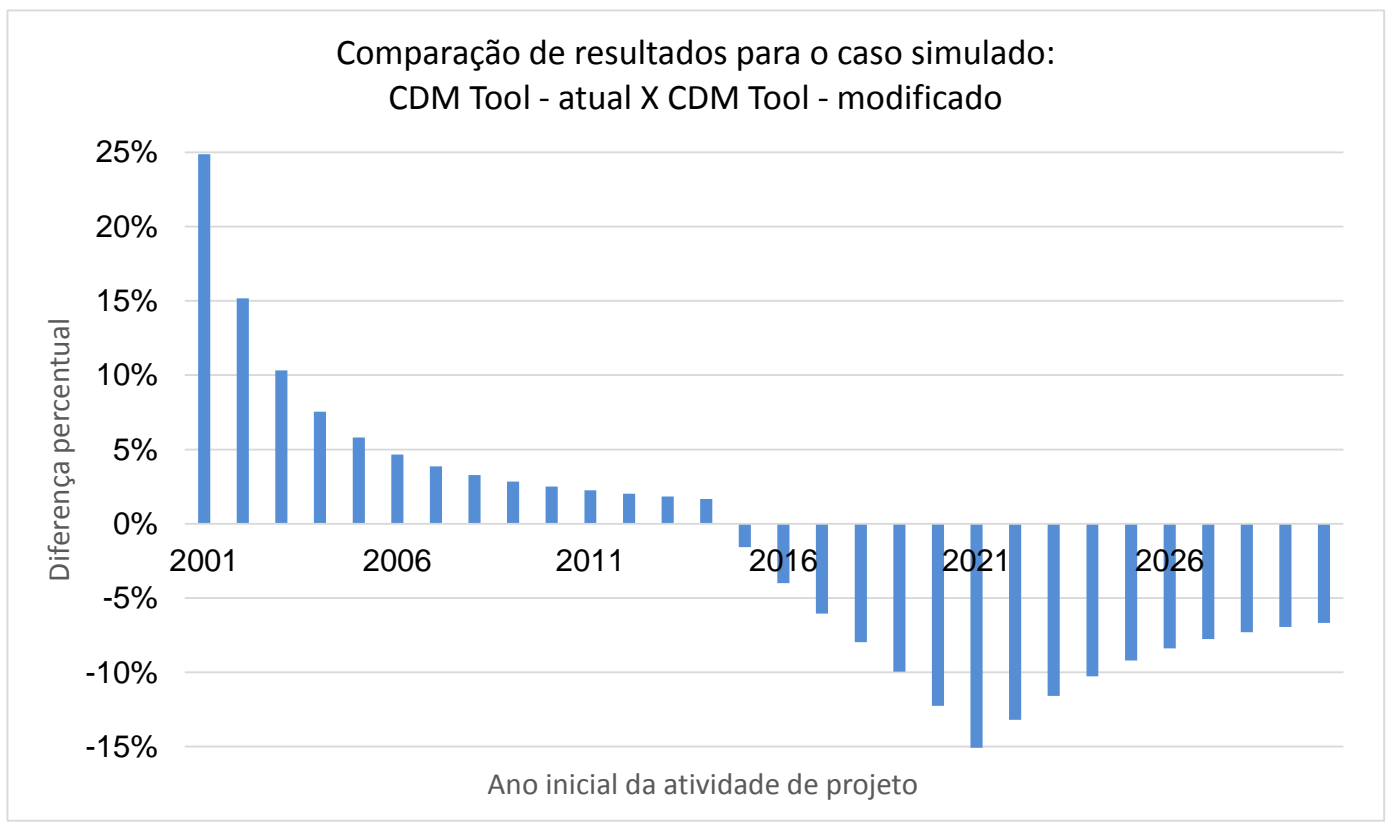

Figura 7 - Geração total de metano segundo o modelo da ferramenta do MDL atual comparada com a da ferramenta corrigida, para projetos com um período de crédito de 7 anos, segundo cada possível ano inicial, para o mesmo caso de simulação da Figura 6

Portanto, erros existem em todas as situações, com diferentes consequências. Enquanto houver mudanças significativas nas quantidades de resíduos depositados, além de eventuais diferenças na composição dos resíduos, as diferenças nas emissões esperadas tendem a ser importantes. 
A interpretação corrente - emissões começando desde o primeiro ano da disposição - pode ser vista nos projetos no website do MDL, onde os documentos de concepção de projeto estão disponíveis juntamente com as planilhas que descrevem os cálculos. Por exemplo, no projeto "Recuperação de gás de aterro, geração de energia e distribuição de biogás do CTR Santa Rosa" ${ }^{\text {30 }}$, referente ao novo aterro servindo ao município do Rio de Janeiro, que começou suas operações em 2011, a planilha "ER calculations.xls", aba "Inputs \& Calculations"31, mostra emissões calculadas com CDM Tool desde o ano da disposição de resíduos. As emissões de metano esperadas para seu período de créditos de sete anos começando em julho de 2012 têm uma superestimação de 18\% em relação ao modelo exato do IPCC (2006) ou do CDM Tool modificado. Caso o cálculo das emissões tivesse usado o CDM Tool atual, apenas sendo iniciando no ano seguinte ao da deposição, haveria uma subestimação de $27 \%$ das emissões no período de créditos.

${ }^{30}$ Esse é um tipo especial de projeto MDL que está sob um Programa de Atividades chamado "Projeto de Gerenciamento de Resíduos Sólidos e de Carbon Finance da Caixa Econômica Federal".

${ }^{31}$ Link http://cdm.unfccc.int/ProgrammeOfActivities/cpa_db/XQMN648JU5LVRAC2OBFE3H1PW0KG 79/view. 


\section{Projetos MDL analisados}

Os aterros estudados tiveram seu potencial para geração de biogás avaliado num primeiro momento e que, mais tarde, tiveram seus modelos de geração e parâmetros reavaliados. Isso acontece no momento da renovação do seu primeiro período de crédito de sete anos, de acordo com os procedimentos do MDL, quando é necessário atualizar a metodologia de linha de base e monitoramento. Apenas quatro projetos MDL no Brasil enquadraram-se nessa condição em maio de 2014, para esta pesquisa.

- Projeto NovaGerar - Projeto de Energia a partir de Gases de Aterro Sanitário - Ref. 0008

- Projeto Bandeirantes de gás de Aterro e Geração de Energia em São Paulo, Brasil - Ref. 0164

- Projeto de Recuperação de Gás de Aterro ESTRE - Paulínia (PROGAE) - Ref. 0165

- Projeto de Redução de Emissões de Biogás, Caieiras - Brasil - Ref. 0171

\subsection{Informações dos projetos a partir de seus PDDs}

\subsubsection{Projeto de Aproveitamento do Biogás de Aterro Sanitário - NovaGerar}

Esse projeto, situado em Nova Iguaçu, na região metropolitana do Rio de Janeiro, pertence ao primeiro conjunto de projetos que teve registro no MDL no mundo, o que mostra que esse mecanismo do Protocolo de Quioto foi logo cedo aproveitado pelos empresários nacionais.

Ele possui dois locais de disposição de resíduos: Marambaia, um lixão que foi transformado em aterro controlado, operando de 1988 a 2002 e Adrianópolis, a partir de 2003. O primeiro período de créditos foi de 01 de julho de 2004 a 30 de junho de 2011, mas o projeto foi operacional apenas a partir de 15 de março de 
2007. O segundo período de créditos considera apenas o aterro de Adrianópolis. Os relatórios de monitoramento trazem dados até 31 de dezembro de 2012.

Embora houvesse a previsão de geração de eletricidade com o metano extraído, tal não ocorreu até 2012.

No primeiro PDD, o modelo utilizado é do IPCC (1997), com o máximo de emissão a partir do ano de disposição; no segundo, de novembro de 2011, o modelo do CDM Tool é usado e há uma atualização dos valores dos resíduos descartados nos últimos sete anos. Neste trabalho, apenas o aterro de Adrianópolis será tratado.

Parâmetros relativos ao modelo do primeiro $P D D$ :

- Constante de decaimento: $\mathrm{k}=0,1 \mathrm{ano}^{-1}$

- Potencial de geração de metano: $\mathrm{L}_{0}=117,14 \mathrm{~m}^{3} \mathrm{CH}_{4} / \mathrm{t}$ resíduos

Esse potencial de geração de metano foi calculado por retroanálise, ou seja, partindo-se dos resultados apresentados para cada ano no PDD e calculando os parâmetros que os geraram, já que os dados indicados no $P D D$ não eram coerentes com os resultados de geração de metano apresentados. Como havia dois aterros envolvidos, e o de Marambaia possuía dados completos das séries anuais de disposição de resíduos, o potencial de geração de metano foi determinado e usado também para Adrianópolis. Para ambos os aterros era indicado um valor original para a geração de biogás de 2,63 pé $3 /$ libra ou $164,2 \mathrm{~m}^{3} / \mathrm{t}$, com uma redução de $20 \%$ pelas incertezas do modelo e com 50\% de metano no biogás, resultando no valor de 65,67 $\mathrm{m}^{3} \mathrm{CH}_{4}$ / t resíduos. Mas apenas com o valor de $117,14 \mathrm{~m}^{3} \mathrm{CH}_{4}$ / t resíduos é que se consegue chegar à previsão de geração apresentada no $P D D$, considerandose que há uma previsão de $85 \%$ de eficiência de coleta, $20 \%$ de desconto na linha de base e uma densidade de metano de $0,00067899 \mathrm{t} / \mathrm{m}^{3}$. Este valor de densidade foi o considerado na época de elaboração do projeto MDL. Já no segundo $P D D$ e nos demais projetos MDL, o valor de densidade considerado era de $0,0007168 \mathrm{t} / \mathrm{m}^{3}$.

Com base nos dois parâmetros do modelo e no resultado de geração prevista para Adrianópolis, identificou-se a série prevista de disposição de resíduos. $\mathrm{Na}$ Tabela 3 estão as duas séries, a do $P D D-1$ e a do $P D D$-2, esta sendo de valores reais até 2011. 
Tabela 3 - Disposição de resíduos em Adrianópolis, segundo o $P D D-1$ e o $P D D-2$

\begin{tabular}{lrrrrr}
\hline \multirow{2}{*}{ Documento } & $\mathbf{2 0 0 3}$ & $\mathbf{2 0 0 4}$ & $\mathbf{2 0 0 5}$ & $\mathbf{2 0 0 6}$ & $\mathbf{2 0 0 7}$ \\
\cline { 2 - 6 } & \multicolumn{5}{c}{ Resíduo (t) } \\
\hline$P D D-1$ & 120.425 & 218.191 & 386.034 & 463.810 & 501.756 \\
\hline$P D D-2$ & 269.266 & 584.306 & 799.400 & 602.272 & 620.823 \\
\hline \multicolumn{5}{c}{ Resíduo (t) } \\
\hline \multirow{2}{*}{ Documento } & $\mathbf{5}$ & $\mathbf{2 0 1 0}$ & $\mathbf{2 0 1 1}$ & $\mathbf{2 0 1 2}$ \\
\cline { 2 - 6 } & $\mathbf{2 0 0 8}$ & $\mathbf{2 0 0 9}$ & $\mathbf{2 0 1 0}$ & 746.442 \\
\hline$P D D-1$ & 536.546 & 582.861 & 640.558 & 695.061 & 1.102 .073 \\
\hline$P D D-2$ & 826.476 & 848.385 & 939.872 & 1.187 .138 & 1.13
\end{tabular}

Fonte: PDD-1 e PDD-2 do "Projeto de Aproveitamento do Biogás de Aterro Sanitário - NovaGerar"

O segundo $P D D$ utiliza o modelo $C D M$ Tool, com os parâmetros que serão mostrados em conjunto com os demais projetos MDL de aterros sanitários analisados neste trabalho.

\subsubsection{Projeto Bandeirantes de Gás de Aterro e Geração de Energia}

O aterro está situado no município de São Paulo. Foi planejado para gerar energia elétrica a partir da queima do metano, o que de fato vem acontecendo. Ele recebeu resíduos de 1979 a 2007. O primeiro período de obtenção de créditos vai de 2004 a 2010. Os relatórios de monitoramento abrangem o período até 31 de agosto de 2012.

No primeiro $P D D$, o modelo do IPCC (1997) é usado, com o máximo de emissão a partir do ano de disposição; no segundo $P D D$, de março de 2012, o modelo do CDM Tool é usado, e há uma atualização dos valores dos resíduos descartados nos últimos sete anos. A disposição de resíduos está mostrada na Tabela 4, segundo o $P D D-1$ e o $P D D-2$, este trazendo valores reais até 2007 , quando o aterro é encerrado.

No $P D D-1$, os valores indicados eram $\mathrm{k}=0,105 \mathrm{ano}^{-1}$ e $\mathrm{L}_{0}=76,73 \mathrm{~m}^{3} \mathrm{CH}_{4} /$ t resíduos (equivalente a 0,055 t $\mathrm{CH}_{4} / \mathrm{t}$ resíduos), mas como esses parâmetros não eram coerentes com os resultados de geração de metano indicados no $P D D$, usouse a retroanálise. Levando-se em conta uma redução de $20 \%$ na linha de base e uma expectativa de extração de $80 \%$, os valores encontrados para o $P D D-1$ foram:

- Constante de decaimento: $\mathrm{k}=0,102 \mathrm{ano}^{-1}$ 
- Potencial de geração de metano: $\mathrm{L}_{0}=84,10 \mathrm{~m}^{3} \mathrm{CH}_{4} / \mathrm{t}$ resíduos

A Tabela 4 apresenta a série anual de disposição de resíduos no $P D D-1$ e no $P D D-2$, quando se acerta os valores até 2007, ano de encerramento do aterro, mas se corrige também os valores de 1998 a 2004, anos anteriores à data do primeiro $P D D$, que é de dezembro de 2005.

O segundo $P D D$ utiliza o modelo $C D M$ Tool, com os parâmetros que serão mostrados em conjunto com os demais aterros mais à frente neste trabalho.

Tabela 4 - Disposição de resíduos em Bandeirantes, segundo o PDD-1 e o PDD-2

\begin{tabular}{|c|c|c|c|c|c|c|}
\hline \multirow{2}{*}{ Documento } & 1979 & 1980 & 1981 & 1982 & 1983 & 1984 \\
\hline & \multicolumn{6}{|c|}{ Resíduos (t) } \\
\hline$P D D-1$ & 37.450 & 229.040 & 231.408 & 313.633 & 321.956 & 325.585 \\
\hline$P D D-2$ & 37.450 & 229.040 & 231.408 & 313.633 & 321.956 & 325.585 \\
\hline \multirow{2}{*}{ Documento } & 1985 & 1986 & 1987 & 1988 & 1989 & 1990 \\
\hline & \multicolumn{6}{|c|}{ Resíduos (t) } \\
\hline$P D D-1$ & 408.887 & 801.366 & 1.017 .866 & 1.283 .852 & 977.852 & 1.206 .964 \\
\hline$P D D-2$ & 408.887 & 801.366 & 1.017 .866 & 1.283 .852 & 977.852 & 1.206 .964 \\
\hline \multirow{2}{*}{ Documento } & 1991 & 1992 & 1993 & 1994 & 1995 & 1996 \\
\hline & \multicolumn{6}{|c|}{ Resíduos (t) } \\
\hline$P D D-1$ & 1.224 .954 & 1.508 .817 & 1.377 .148 & 1.616 .710 & 1.823 .170 & 1.971 .651 \\
\hline$P D D-2$ & 1.224 .954 & 1.508 .817 & 1.377 .148 & 1.616 .710 & 1.823 .170 & 1.971 .651 \\
\hline \multirow{2}{*}{ Documento } & 1997 & 1998 & 1999 & 2000 & 2001 & 2002 \\
\hline & \multicolumn{6}{|c|}{ Resíduos (t) } \\
\hline$P D D-1$ & 1.992 .386 & 1.874 .272 & 1.741 .945 & 1.761 .378 & 1.746 .225 & 1.973 .004 \\
\hline$P D D-2$ & 1.992 .386 & 2.142 .325 & 2.305 .464 & 1.964 .424 & 2.043 .617 & 2.082 .855 \\
\hline \multirow{2}{*}{ Documento } & 2003 & 2004 & 2005 & 2006 & 2007 & 2008 \\
\hline & \multicolumn{6}{|c|}{ Resíduos (t) } \\
\hline$P D D-1$ & 1.792 .587 & 1.845 .724 & 1.850 .000 & 1.850 .000 & & \\
\hline$P D D-2$ & 1.993.371 & 1.965 .347 & 1.594 .350 & 1.974 .799 & 489.627 & \\
\hline
\end{tabular}

Fonte: PDD-1 e PDD-2 do "Projeto Bandeirantes de Gás de Aterro e Geração de Energia"

\subsubsection{Projeto de Recuperação de Gás de Aterro ESTRE - Paulínia}

O aterro recebe resíduos desde 2000. O primeiro período de obtenção de créditos vai de 2006 a 2012. No entanto, o primeiro PDD foi revisto em janeiro de 2012 para correções, não só no período de créditos, agora indo de 14 de setembro 
de 2006 a 13 de setembro de 2013, mas também na quantidade de resíduos anuais depositados e nos parâmetros do modelo. Os relatórios de monitoramento abrangem o período de 14 de setembro de 2006 a 30 setembro de 2012.

No primeiro $P D D$, em qualquer versão, o modelo do IPCC (1997) é usado, com o máximo de emissões desde o ano da disposição; no segundo $P D D$, de junho de 2013, o modelo CDM Tool é usado, e há uma atualização da quantidade de resíduos eliminados em 2012.

Parâmetros relativos ao modelo do primeiro $P D D$, que acabou não sendo utilizado nesta análise:

- Constante de decaimento: $\mathrm{k}=0,12 \mathrm{ano}^{-1}$

- Potencial de geração de metano: $\mathrm{L}_{0}=62,99 \mathrm{~m}^{3} \mathrm{CH}_{4} / \mathrm{t}$ resíduos

No $P D D-1$, indicava-se o valor $\mathrm{L}_{0}=79,52 \mathrm{~m}^{3} \mathrm{CH}_{4} / \mathrm{t}$ resíduos (equivalente a 0,057 t $\mathrm{CH}_{4} / \mathrm{t}$ resíduos), mas como esse parâmetro não era coerente com os resultados de geração de metano indicados no $P D D$, usou-se a retroanálise para se chegar ao valor acima. Nesse cálculo, leva-se em conta também uma redução de $20 \%$ na linha de base e uma expectativa de extração de $80 \%$.

A revisão do $P D D-1$ fez-se necessária por causa do aumento substancial da geração de metano não prevista originalmente e que se refletiria numa quantidade maior de créditos de carbono gerada. Nesse caso, as regras do MDL impõem explicações e revisões do projeto. Assim, foram revisados não só os dados de disposição como também os parâmetros do modelo, que passaram a ser:

- Constante de decaimento: $\mathrm{k}=0,09 \mathrm{ano}^{-1}$

- Potencial de geração de metano: $\mathrm{L}_{0}=140 \mathrm{~m}^{3} \mathrm{CH}_{4} / \mathrm{t}$ resíduos

A Tabela 5 mostra a série anual de disposição de resíduos no $P D D-1$, no PDD-1_Rev, quando se atualiza os valores de 2004 até 2011, e no PDD-2, quando se acerta os valores de 2012 e se altera o fim previsto para o aterro, agora para 2015. 
Tabela 5 - Disposição de resíduos em ESTRE-Paulínia, segundo o $P D D-1$, o $P D D-1 \_R e v$ e o $P D D-2$

\begin{tabular}{|c|c|c|c|c|c|c|c|c|}
\hline \multirow{2}{*}{ Documento } & 2000 & 2001 & 2002 & 2003 & 2004 & 2005 & 2006 & 2007 \\
\hline & \multicolumn{8}{|c|}{ Resíduos (t) } \\
\hline$P D D-1$ & 33.015 & 191.465 & 597.361 & 351.373 & 597.361 & 597.361 & 597.361 & 597.361 \\
\hline$P D D-1 \_R e v$ & 33.015 & 191.465 & 597.361 & 351.373 & 730.195 & 792.689 & 1.004 .799 & 1.335 .269 \\
\hline$P D D-2$ & 64.800 & 185.000 & 673.017 & 803.523 & 730.195 & 792.689 & 1.004 .799 & 1.335 .269 \\
\hline \multirow{2}{*}{ Documento } & 2008 & 2009 & 2010 & 2011 & 2012 & 2013 & 2014 & 2015 \\
\hline & \multicolumn{8}{|c|}{ Resíduos (t) } \\
\hline$P D D-1$ & 597.361 & 597.361 & 597.361 & & & & & \\
\hline$P D D-1 \_$Rev & 1.507 .775 & 1.418 .013 & 1.675 .331 & 1.658 .122 & 1.620 .000 & 1.620 .000 & 1.590 .758 & \\
\hline$P D D-2$ & 1.507 .775 & 1.418 .013 & 1.675 .331 & 1.658 .430 & 1.663 .664 & 1.620 .000 & 1.620 .000 & 1.674 .866 \\
\hline
\end{tabular}

\subsubsection{Redução de emissões de gás de aterro de Caieiras}

O aterro recebe resíduos desde 2002. O primeiro período de obtenção de créditos vai de 31 de março de 2006 a 30 de março de 2013, mas o projeto foi operacional apenas a partir de 01 de fevereiro de 2007. No entanto, o primeiro PDD foi revisto em janeiro de 2013 para correções significativas relativamente às quantidades anuais depositadas. Os relatórios de monitoramento abrangem o período de 01 de fevereiro de 2007 a 30 de Setembro de 2012.

No primeiro $P D D$, usou-se o modelo do IPCC (1997); já em sua revisão, foi utilizado o modelo do IPCC (2000), ambos usando o máximo de emissões desde o ano de disposição. No segundo PDD, de setembro de 2013, o modelo do CDM Tool é usado. O projeto previa um desconto de linha de base que seria a quantidade de metano usada para gerar eletricidade exportada ou $20 \%$ do que fosse captado. Como não houve geração de eletricidade, prevaleceu o desconto de $20 \%$ na linha de base. Quanto à eficiência de extração, previu-se 60\% em 2006, 70\% em 2007 e 80\% de 2008 em diante. De fato, só ocorreu captação de metano a partir de 2007.

No modelo IPCC (1997), do PDD-1, a constante de decaimento e o potencial de geração de metano são fornecidos diretamente: $\mathrm{k}=0,08 \mathrm{ano}^{-1} \mathrm{e} \mathrm{L}_{0}=116 \mathrm{~m}^{3} \mathrm{CH}_{4}$ I t resíduos, mas os resultados só se verificam se for alterado o segundo parâmetro para $\mathrm{L}_{0}=111,28 \mathrm{~m}^{3} \mathrm{CH}_{4} / \mathrm{t}$ resíduos. No $P D D-1 \_\mathrm{Rev}$, utilizou-se o modelo do IPCC (2000), com a mesma constante de decaimento e mais os seguintes dados, que permitem calcular o potencial de geração de metano:

Fração de papel, papelão e têxteis $=22,0 \%$ 
Fração de restos de alimentos e resíduos orgânicos $=43,0 \%$

Fração de madeiras: $2,0 \%$

$\mathrm{MCF}=1$

$\mathrm{DOC}_{\mathrm{f}}=0,77$

$\mathrm{F}=50 \%$

Então:

$\mathrm{DOC}=0,4 * 22,0 \%+0,16 * 43,0 \%+0,3 * 2,0 \%=0,162$

$\mathrm{L}_{0}=\mathrm{MCF} * \mathrm{DOC} * \mathrm{DOC}_{\mathrm{f}} * \mathrm{~F} * 16 / 12\left[\mathrm{t} \mathrm{CH}_{4}\right]$

$\mathrm{L}_{0}=1 * 0,162 * 0,77 * 0,5 * 16 / 12 / 0,0007168\left[\mathrm{~m}^{3} \mathrm{CH}_{4}\right]$

$\mathrm{L}_{0}=116 \mathrm{~m}^{3} \mathrm{CH}_{4}=0,083 \mathrm{t}_{\mathrm{CH} 4}$

Neste trabalho, considerou-se apenas o modelo do $P D D-1 \_$Rev, que ainda precisa um pequeno ajuste em $L_{0}$ para atingir os valores de geração apresentados nesse documento. Assim, os parâmetros ficam definidos como:

- Constante de decaimento: $\mathrm{k}=0,08 \mathrm{ano}^{-1}$

- Potencial de geração de metano: $\mathrm{L}_{0}=115,78 \mathrm{~m}^{3} \mathrm{CH}_{4} / \mathrm{t}$ resíduos

A Tabela 6 mostra a série anual de disposição de resíduos no $P D D-1$, no PDD-1_Rev, quando se atualiza os valores de 2005 até 2012, e no PDD-2, quando se revisa mais uma vez a série desde 2002 até 2012. A revisão do $P D D-1$ foi motivada pelo aumento substancial da disposição de resíduos e que se refletia numa quantidade maior de créditos de carbono gerada. Nesse caso, as regras do MDL impõem explicações e revisões do projeto.

Tabela 6 - Disposição de resíduos em Caieiras, segundo o PDD-1, PDD-1_Rev e PDD-2

\begin{tabular}{|c|c|c|c|c|c|c|}
\hline \multirow{2}{*}{ Documento } & 2002 & 2003 & 2004 & 2005 & 2006 & 2007 \\
\hline & \multicolumn{6}{|c|}{ Resíduos (t) } \\
\hline$P D D-1$ & 70.979 & 415.810 & 454.354 & 730.000 & 730.000 & 1.460 .000 \\
\hline$P D D-1 \_$Rev & 70.981 & 415.797 & 454.349 & 701.725 & 735.517 & 2.111 .539 \\
\hline$P D D-2$ & 73.150 & 453.385 & 468.668 & 1.025 .361 & 838.415 & 2.087 .299 \\
\hline
\end{tabular}


Tabela 6 (continuação)

\begin{tabular}{lcccccc}
\hline \multirow{2}{*}{ Documento } & $\mathbf{2 0 0 8}$ & $\mathbf{2 0 0 9}$ & $\mathbf{2 0 1 0}$ & $\mathbf{2 0 1 1}$ & $\mathbf{2 0 1 2}$ & $\mathbf{2 0 1 3}$ \\
\cline { 2 - 7 } & \multicolumn{5}{c}{ Resíduos (t) } \\
\hline$P D D-1$ & 1.460 .000 & 1.460 .000 & 1.460 .000 & 1.460 .000 & 1.460 .000 & 1.460 .000 \\
\hline$P D D-1 \_\operatorname{Rev}$ & 2.881 .103 & 2.580 .009 & 3.450 .052 & 3.283 .595 & 3.096 .657 & 3.158 .590 \\
\hline$P D D-2$ & 2.871 .149 & 2.582 .697 & 3.450 .356 & 3.283 .639 & 3.100 .029 & 3.162 .030 \\
\hline Fonte: PDD-1, PDD-1 revisado e PDD-2 do projeto "Redução de emissões de gás de aterro de Caieiras"
\end{tabular}

\subsection{Análise dos relatórios de monitoramento}

Conforme informado no Capítulo 2 - Metodologia, os relatórios de monitoramento foram recuperados do site do MDL, na seção Requests for Issuance and related documentation de cada uma das atividades de projeto, não o que era apresentado logo à vista, mas o que aparecia em sua história completa (full history), para se obter a última versão aprovada, com eventuais planilhas de cálculo em anexo.

Os resultados utilizados para o presente estudo foram os obtidos de medições diretas das atividades de projeto e posteriormente corrigidos pelas incertezas dos instrumentos de medida, segundo fórmulas estabelecidas.

Os valores de captação de metano, obtidos a partir da quantidade de biogás e da fração medida do metano, estão organizados por ano. Em alguns casos, onde não havia a parte inicial do primeiro ano ou a final do último ano, uma extrapolação simples foi feita para completá-los e, assim, obter uma mesma base de comparação com os modelos, que mostram resultados anuais.

\subsubsection{NovaGerar}

A atividade de projeto refere-se aos dois locais, Marambaia e Adrianópolis. Aqui são apresentados os resultados para ambos, embora apenas os de Adrianópolis sejam utilizados para os cálculos de eficiência de extração do metano, segundo os modelos de geração. Os valores medidos do metano recuperado são apresentados diretamente por mês, em $\mathrm{CO}_{2} \mathrm{e}$, em planilhas auxiliares apresentadas junto aos relatórios de monitoramento, na seção full history de cada um dos períodos de monitoramento. Não houve, portanto, necessidade de maiores considerações relativamente a linha de base, uso de combustível ou geração de eletricidade, que não aconteceu até o final do período monitorado. Foram seis os períodos 
consecutivos monitorados, de 2007 até o final de 2012, sendo que, apenas para Adrianópolis, o segundo período de créditos começou em 01 de julho de 2011.

Endereço do projeto na página do MDL:

http://cdm.UNFCCC.int/Projects/DB/DNV-CUK1095236970.6/view

Tabela 7 - Dados de oxidação de metano por mês, em $\mathrm{CO}_{2} \mathrm{e}$, para NovaGerar

\begin{tabular}{|c|c|c|c|c|c|}
\hline \multirow{3}{*}{ Ano } & \multirow{3}{*}{ Mês } & Marambaia & Adrianópolis & Marambaia & $\begin{array}{c}\text { Adrianópoli } \\
\mathbf{S}\end{array}$ \\
\hline & & \multicolumn{4}{|c|}{ Metano oxidado } \\
\hline & & \multicolumn{2}{|c|}{$\mathrm{tCO}_{2} \mathrm{e}$} & \multicolumn{2}{|c|}{$\mathrm{t} \mathrm{CH}_{4}$} \\
\hline \multirow{12}{*}{2007} & Jan & & & - & - \\
\hline & Fev & & & - & - \\
\hline & Mar & & $1.521,86$ & - & 72,47 \\
\hline & Abr & & $3.966,57$ & - & 188,88 \\
\hline & Mai & 218,90 & $5.823,61$ & 10,42 & 277,31 \\
\hline & Jun & 614,40 & $6.723,96$ & 29,26 & 320,19 \\
\hline & Jul & 313,52 & $6.624,27$ & 14,93 & 315,44 \\
\hline & Ago & 490,04 & $7.787,09$ & 23,34 & 370,81 \\
\hline & Set & 446,67 & $7.389,03$ & 21,27 & 351,86 \\
\hline & Out & 327,55 & $8.247,61$ & 15,60 & 392,74 \\
\hline & Nov & 537,00 & $8.253,40$ & 25,57 & 393,02 \\
\hline & Dez & 538,16 & $8.180,83$ & 25,63 & 389,56 \\
\hline \multicolumn{2}{|l|}{ Total } & $3.486,24$ & $64.518,23$ & 166,01 & $3.072,30$ \\
\hline \multirow{12}{*}{2008} & Jan & 43,97 & $7.518,52$ & 2,09 & 358,02 \\
\hline & Fev & 28,04 & $6.797,06$ & 1,34 & 323,67 \\
\hline & Mar & 40,51 & $6.840,28$ & 1,93 & 325,73 \\
\hline & Abr & 317,08 & $6.075,90$ & 15,10 & 289,33 \\
\hline & Mai & 212,42 & $5.924,54$ & 10,12 & 282,12 \\
\hline & Jun & 70,35 & $5.303,23$ & 3,35 & 252,53 \\
\hline & Jul & 32,83 & $6.308,52$ & 1,56 & 300,41 \\
\hline & Ago & 178,77 & $5.968,29$ & 8,51 & 284,20 \\
\hline & Set & 193,68 & $5.330,04$ & 9,22 & 253,81 \\
\hline & Out & 423,13 & $7.482,29$ & 20,15 & 356,30 \\
\hline & Nov & 237,39 & $8.178,47$ & 11,30 & 389,45 \\
\hline & Dez & 180,88 & $8.246,14$ & 8,61 & 392,67 \\
\hline Total & & $1.959,05$ & $79.973,28$ & 93,29 & $3.808,25$ \\
\hline
\end{tabular}


Tabela 7 (continuação)

\begin{tabular}{|c|c|c|c|c|c|}
\hline \multirow{3}{*}{ Ano } & \multirow{3}{*}{ Mês } & Marambaia & Adrianópolis & Marambaia & $\begin{array}{c}\text { Adrianópoli } \\
s\end{array}$ \\
\hline & & \multicolumn{4}{|c|}{ Metano oxidado } \\
\hline & & \multicolumn{2}{|c|}{$\mathrm{tCO}_{2} \mathrm{e}$} & \multicolumn{2}{|c|}{$\mathrm{tCH}_{4}$} \\
\hline \multirow{12}{*}{2009} & Jan & 273,88 & $6.869,85$ & 13,04 & 327,14 \\
\hline & Fev & 69,02 & $5.030,57$ & 3,29 & 239,55 \\
\hline & Mar & 236,27 & $7.003,65$ & 11,25 & 333,51 \\
\hline & Abr & 366,01 & $8.343,23$ & 17,43 & 397,30 \\
\hline & Mai & 269,61 & $8.594,37$ & 12,84 & 409,26 \\
\hline & Jun & 314,82 & $8.008,69$ & 14,99 & 381,37 \\
\hline & Jul & 296,42 & $7.764,20$ & 14,12 & 369,72 \\
\hline & Ago & 321,95 & $4.102,61$ & 15,33 & 195,36 \\
\hline & Set & 240,48 & $5.602,55$ & 11,45 & 266,79 \\
\hline & Out & 448,27 & $6.765,98$ & 21,35 & 322,19 \\
\hline & Nov & 357,00 & $6.069,53$ & 17,00 & 289,03 \\
\hline & Dez & 157,02 & $5.836,33$ & 7,48 & 277,92 \\
\hline \multirow[t]{6}{*}{ Total } & & $3.350,75$ & $79.991,56$ & 159,56 & $3.809,12$ \\
\hline & Jan & 56,00 & $5.229,00$ & 2,67 & 249,00 \\
\hline & Fev & 16,00 & $4.560,00$ & 0,76 & 217,14 \\
\hline & Mar & 68,00 & $6.496,00$ & 3,24 & 309,33 \\
\hline & Abr & 15,00 & $7.565,00$ & 0,71 & 360,24 \\
\hline & Mai & 4,00 & $7.440,00$ & 0,19 & 354,29 \\
\hline \multirow{7}{*}{2010} & Jun & 110,00 & $9.558,00$ & 5,24 & 455,14 \\
\hline & Jul & 112,00 & $10.196,00$ & 5,33 & 485,52 \\
\hline & Ago & 170,00 & $10.092,00$ & 8,10 & 480,57 \\
\hline & Set & 59,00 & $9.613,00$ & 2,81 & 457,76 \\
\hline & Out & 16,00 & $9.327,00$ & 0,76 & 444,14 \\
\hline & Nov & 12,00 & $9.221,00$ & 0,57 & 439,10 \\
\hline & Dez & 127,00 & $11.884,00$ & 6,05 & 565,90 \\
\hline \multicolumn{2}{|l|}{ Total } & 765,00 & $101.181,00$ & 36,43 & $4.818,14$ \\
\hline \multirow{12}{*}{2011} & Jan & & $9.451,00$ & - & 450,05 \\
\hline & Fev & & $8.923,00$ & - & 424,90 \\
\hline & Mar & & $10.857,00$ & - & 517,00 \\
\hline & Abr & & $12.339,00$ & - & 587,57 \\
\hline & Mai & & $13.228,00$ & - & 629,90 \\
\hline & Jun & & & - & - \\
\hline & Jul & \multirow{6}{*}{$\begin{array}{l}\text { Segundo } \\
\text { período de } \\
\text { créditos, só } \\
\text { Adrianópolis }\end{array}$} & $12.415,00$ & - & 591,19 \\
\hline & Ago & & $12.238,00$ & - & 582,76 \\
\hline & Set & & $10.238,00$ & - & 487,52 \\
\hline & Out & & $10.654,00$ & - & 507,33 \\
\hline & Nov & & $11.625,00$ & - & 553,57 \\
\hline & Dez & & $11.990,00$ & - & 570,95 \\
\hline Total & & - & $123.958,00$ & - & $5.902,76$ \\
\hline
\end{tabular}


Tabela 7 (continuação)

\begin{tabular}{|c|c|c|c|c|c|}
\hline \multirow{3}{*}{ Ano } & \multirow{3}{*}{ Mês } & Marambaia & Adrianópolis & Marambaia & $\begin{array}{c}\text { Adrianópoli } \\
\mathrm{s}\end{array}$ \\
\hline & & \multicolumn{4}{|c|}{ Metano oxidado } \\
\hline & & \multicolumn{2}{|c|}{$\mathrm{t} \mathrm{CO}_{2} \mathrm{e}$} & \multicolumn{2}{|c|}{$\mathrm{tCH}_{4}$} \\
\hline \multirow{12}{*}{2012} & Jan & \multirow{12}{*}{$\begin{array}{l}\text { Segundo } \\
\text { período de } \\
\text { créditos, só } \\
\text { Adrianópolis }\end{array}$} & $8.800,00$ & - & 419,05 \\
\hline & Fev & & $6.677,00$ & - & 317,95 \\
\hline & Mar & & $9.683,00$ & - & 461,10 \\
\hline & Abr & & $9.973,00$ & - & 474,90 \\
\hline & Mai & & $10.472,00$ & - & 498,67 \\
\hline & Jun & & $7.601,00$ & - & 361,95 \\
\hline & Jul & & $10.165,00$ & - & 484,05 \\
\hline & Ago & & $8.044,00$ & - & 383,05 \\
\hline & Set & & $9.999,00$ & - & 476,14 \\
\hline & Out & & $8.177,00$ & - & 389,38 \\
\hline & Nov & & $7.294,00$ & - & 347,33 \\
\hline & Dez & & $5.632,00$ & - & 268,19 \\
\hline Total & & - & $102.517,00$ & - & $4.881,76$ \\
\hline
\end{tabular}

A Tabela 8 apresenta os ajustes para se completar o ano de 2007, com base nas médias diárias da parte monitorada desse ano.

Tabela 8 - Cálculo do ajuste para completar o ano de 2007

\begin{tabular}{lrrrrr}
\hline & \multicolumn{5}{c}{ Ajuste de 2007, pela média diária } \\
\cline { 2 - 6 } Aterro & Data inicial & Data final & $\begin{array}{c}\text { Dias } \\
\text { monitorados }\end{array}$ & $\begin{array}{c}\text { Média diária } \\
(\mathrm{t} \mathrm{CH} / \text { dia })\end{array}$ & $\begin{array}{c}\text { Dias incluídos } \\
\text { para completar } \\
\text { o ano, pela } \\
\text { média diária }\end{array}$ \\
\hline Marambaia & $17 / 05 / 2007$ & $31 / 12 / 2007$ & 229 & 0,72 & 136 \\
\hline Adrianópolis & $15 / 03 / 2007$ & $31 / 12 / 2007$ & 292 & 10,52 & 73 \\
\hline
\end{tabular}

A Tabela 9 apresenta os valores de metano para a comparação anual com os modelos.

Tabela 9 - Quantidade de metano captado, ou oxidado, no projeto NovaGerar por ano

\begin{tabular}{lrrrrrr}
\hline \multirow{2}{*}{ Aterro } & $\begin{array}{r}2007 \\
\text { (ajustado) }\end{array}$ & 2008 & 2009 & 2010 & 2011 & 2012 \\
\cline { 2 - 7 } & \multicolumn{7}{c}{$\mathrm{t} \mathrm{CH}_{4}$} \\
\hline Marambaia & 264,60 & 93,29 & 159,56 & 36,43 & - & - \\
\hline Adrianópolis & $3.840,37$ & $3.808,25$ & $3.809,12$ & $4.818,14$ & $5.902,76$ & $4.881,76$ \\
\hline Total & $4.104,97$ & $3.901,54$ & $3.968,68$ & $4.854,57$ & $5.902,76$ & $4.881,76$ \\
\hline
\end{tabular}




\subsubsection{Bandeirantes}

Para esta atividade de projeto, os valores de metano oxidado são apresentados nos relatórios de monitoramento finais - seção full history - já com o desconto de linha de base de 20\%, para indicar as reduções na linha de base. Fez-se necessário, então, a retirada desse desconto para a obtenção do valor de metano oxidado de fato. A Tabela 10 apresenta os valores de metano em $\mathrm{CO}_{2} \mathrm{e}$, com uma indicação da página em que se encontra a informação no relatório de monitoramento de cada um dos períodos, e o valor da oxidação de metano sem o desconto. Ela também apresenta o valor do metano oxidado por dia para permitir a quebra dos períodos que incluem mais de um ano calendário, possibilitando a montagem da Tabela 11, com os valores anuais para comparação com os modelos. Note-se que nessa tabela, o ano de 2012 é completado com 122 dias baseando-se na média do último período monitorado. Foram 18 períodos consecutivos monitorados, do início de 2004 até o final de agosto de 2012. O segundo período de créditos iniciou em 23/12/2010.

Endereço do projeto na página do MDL:

http://cdm.UNFCCC.int/Projects/DB/DNV-CUK1134130255.56/view

Tabela 10 - Dados de reduções na linha de base por período, em $\mathrm{CO}_{2} \mathrm{e}$, para Bandeirantes

\begin{tabular}{|c|c|c|c|c|c|c|c|}
\hline \multirow[t]{2}{*}{$\begin{array}{c}\text { Relatório de } \\
\text { Monitoramento } \\
\text { (MR) }\end{array}$} & \multirow[t]{2}{*}{ Data início } & \multirow[t]{2}{*}{ Data fim } & \multirow[t]{2}{*}{ Dias } & $\begin{array}{c}\text { Redução } \\
\text { na linha } \\
\text { de base }\end{array}$ & \multirow[t]{2}{*}{$\begin{array}{l}\text { Linha } \\
\text { de } \\
\text { base }\end{array}$} & $\begin{array}{c}\text { Total } \\
\text { oxidado }\end{array}$ & $\begin{array}{c}\text { Oxidado } \\
\text { por dia }\end{array}$ \\
\hline & & & & $\mathrm{t} \mathrm{CO}_{2} \mathrm{e}$ & & \multicolumn{2}{|c|}{ t $\mathrm{CO}_{2} \mathrm{e}$} \\
\hline \multirow{2}{*}{ MR01 pág. 42} & $01 / 01 / 2004$ & $11 / 09 / 2004$ & 255 & 298.989 & $20 \%$ & $373.736,25$ & $1.465,63$ \\
\hline & $13 / 09 / 2004$ & 28/02/2006 & 534 & 801.662 & $20 \%$ & $1.002 .077,50$ & $1.876,55$ \\
\hline MR02 pág. 15 & 01/03/2006 & $30 / 09 / 2006$ & 214 & 353.232 & $20 \%$ & $441.539,68$ & $2.063,27$ \\
\hline MR03 pág. 17 & $01 / 10 / 2006$ & $31 / 12 / 2006$ & 92 & 133.478 & $20 \%$ & $166.847,50$ & $1.813,56$ \\
\hline MR04 pág. 39 & $01 / 01 / 2007$ & $30 / 06 / 2007$ & 181 & 337.544 & $20 \%$ & $421.930,00$ & $2.331,10$ \\
\hline MR05 pág. 36 & $01 / 07 / 2007$ & $31 / 10 / 2007$ & 123 & 236.375 & $20 \%$ & $295.468,75$ & $2.402,18$ \\
\hline MR06 pág. 31 & $01 / 11 / 2007$ & $31 / 12 / 2007$ & 61 & 114.156 & $20 \%$ & $142.695,00$ & $2.339,26$ \\
\hline MR07 pág. 35 & 01/01/2008 & $31 / 03 / 2008$ & 91 & 171.007 & $20 \%$ & $213.758,75$ & $2.349,00$ \\
\hline MR08 pág. 34 & $01 / 04 / 2008$ & $30 / 06 / 2008$ & 91 & 150.444 & $20 \%$ & 188.055 & $2.066,54$ \\
\hline MR09 pág. 33 & $01 / 07 / 2008$ & $30 / 09 / 2008$ & 92 & 120.237 & $20 \%$ & 150.296 & $1.633,65$ \\
\hline MR10 pág. 32 & $01 / 10 / 2008$ & $30 / 11 / 2008$ & 61 & 74.692 & $20 \%$ & 93.365 & $1.530,57$ \\
\hline MR11 pág. 38 & $01 / 12 / 2008$ & $31 / 03 / 2009$ & 121 & 135.996 & $20 \%$ & 169.995 & $1.404,92$ \\
\hline MR12 pág. 48 & $01 / 04 / 2009$ & $30 / 06 / 2009$ & 91 & 83.122 & $20 \%$ & 103.903 & $1.141,79$ \\
\hline
\end{tabular}


Tabela 10 (continuação)

\begin{tabular}{lrrrrrrr}
\hline MR13 pág. 50 & $01 / 07 / 2009$ & $30 / 09 / 2009$ & 92 & 83.528 & $20 \%$ & 104.410 & $1.134,89$ \\
\hline MR14 pág. 50 & $01 / 10 / 2009$ & $31 / 12 / 2009$ & 92 & 82.251 & $20 \%$ & 102.814 & $1.117,54$ \\
\hline MR15 pág. 3 & $01 / 01 / 2010$ & $31 / 07 / 2010$ & 212 & 180.717 & $20 \%$ & 225.896 & $1.065,55$ \\
\hline MR16 pág. 3 & $01 / 08 / 2010$ & $31 / 10 / 2010$ & 92 & 66.780 & $20 \%$ & 83.475 & 907,34 \\
\hline MR17 pág. 3 & $01 / 11 / 2010$ & $22 / 12 / 2010$ & 52 & 38.522 & $20 \%$ & 48.153 & 926,01 \\
\hline MR18 pág. 2 & $23 / 12 / 2010$ & $31 / 08 / 2012$ & 618 & 403.485 & $20 \%$ & 504.356 & 816,11 \\
\hline
\end{tabular}

Tabela 11 - Cálculo do metano captado, ou oxidado, no Projeto Bandeirantes por ano

\begin{tabular}{|c|c|c|c|c|c|c|}
\hline \multirow{2}{*}{ Início } & \multirow{2}{*}{ Fim } & \multirow{2}{*}{ Dias } & \multirow{2}{*}{$\frac{\text { Metano oxidado }}{\mathrm{t} \mathrm{CO}_{2} \mathrm{e}}$} & \multirow{2}{*}{$\begin{array}{l}\text { No } \\
\text { ano }\end{array}$} & \multicolumn{2}{|c|}{ Metano oxidado } \\
\hline & & & & & $\mathrm{tCO}_{2} \mathrm{e}$ & $\mathrm{t} \mathrm{CH}_{4}$ \\
\hline $01 / 01 / 2004$ & $11 / 09 / 2004$ & 255 & $373.736,25$ & \multirow{2}{*}{2004} & \multirow{2}{*}{$580.156,71$} & \multirow{2}{*}{$27.626,51$} \\
\hline $13 / 09 / 2004$ & $31 / 12 / 2004$ & 110 & $206.420,46$ & & & \\
\hline $01 / 01 / 2005$ & $31 / 12 / 2005$ & 365 & $684.940,61$ & 2005 & $684.940,61$ & $32.616,22$ \\
\hline $01 / 01 / 2006$ & $28 / 02 / 2006$ & 59 & $110.716,43$ & \multirow{3}{*}{2006} & \multirow{3}{*}{$719.103,61$} & \multirow{3}{*}{$34.243,03$} \\
\hline $01 / 03 / 2006$ & $30 / 09 / 2006$ & 214 & $441.539,68$ & & & \\
\hline $01 / 10 / 2006$ & $31 / 12 / 2006$ & 92 & $166.847,50$ & & & \\
\hline $01 / 01 / 2007$ & $30 / 06 / 2007$ & 181 & $421.930,00$ & \multirow{3}{*}{2007} & \multirow{3}{*}{$860.093,75$} & \multirow{3}{*}{$40.956,85$} \\
\hline 01/07/2007 & $31 / 10 / 2007$ & 123 & $295.468,75$ & & & \\
\hline $01 / 11 / 2007$ & $31 / 12 / 2007$ & 61 & $142.695,00$ & & & \\
\hline 01/01/2008 & $31 / 03 / 2008$ & 91 & $213.758,75$ & \multirow{5}{*}{2008} & \multirow{5}{*}{$689.027,44$} & \multirow{5}{*}{$32.810,83$} \\
\hline $01 / 04 / 2008$ & $30 / 06 / 2008$ & 91 & $188.055,00$ & & & \\
\hline 01/07/2008 & $30 / 09 / 2008$ & 92 & $150.296,25$ & & & \\
\hline $01 / 10 / 2008$ & $30 / 11 / 2008$ & 61 & $93.365,00$ & & & \\
\hline $01 / 12 / 2008$ & $31 / 12 / 2008$ & 31 & $43.552,44$ & & & \\
\hline $01 / 01 / 2009$ & $31 / 03 / 2009$ & 90 & $126.442,56$ & \multirow{4}{*}{2009} & \multirow{4}{*}{$437.568,81$} & \multirow{4}{*}{$20.836,61$} \\
\hline $01 / 04 / 2009$ & $30 / 06 / 2009$ & 91 & $103.902,50$ & & & \\
\hline $01 / 07 / 2009$ & $30 / 09 / 2009$ & 92 & $104.410,00$ & & & \\
\hline $01 / 10 / 2009$ & $31 / 12 / 2009$ & 92 & $102.813,75$ & & & \\
\hline $01 / 01 / 2010$ & $31 / 07 / 2010$ & 212 & $225.896,25$ & \multirow{4}{*}{2010} & \multirow{4}{*}{$364.868,74$} & \multirow{4}{*}{$17.374,70$} \\
\hline $01 / 08 / 2010$ & $31 / 10 / 2010$ & 92 & $83.475,00$ & & & \\
\hline $01 / 11 / 2010$ & $22 / 12 / 2010$ & 52 & $48.152,50$ & & & \\
\hline $23 / 12 / 2010$ & $31 / 12 / 2010$ & 9 & $7.344,99$ & & & \\
\hline $01 / 01 / 2011$ & $31 / 12 / 2011$ & 365 & $297.880,31$ & 2011 & $297.880,31$ & $14.184,78$ \\
\hline 01/01/2012 & $31 / 08 / 2012$ & 244 & $199.130,95$ & \multirow{2}{*}{2012} & \multirow{2}{*}{$298.696,42$} & \multirow{2}{*}{$14.223,64$} \\
\hline Para comp & etaro ano & 122 & $99.565,47$ & & & \\
\hline
\end{tabular}




\subsubsection{ESTRE-Paulínia}

Também neste caso, os valores de metano oxidado são apresentados nos relatórios de monitoramento finais - seção full history - já com o desconto de linha de base de $20 \%$, para indicar as reduções na linha de base. A

Tabela 12 apresenta os valores de metano em $\mathrm{CO}_{2} \mathrm{e}$, com uma indicação da página do relatório de monitoramento em que se encontra a informação, em cada um dos períodos. A tabela também apresenta o valor do metano oxidado por dia, calculado após a retirada do desconto de linha de base, para permitir a quebra dos períodos que incluem mais de um ano calendário, possibilitando a montagem da Tabela 13, com os valores anuais de oxidação de metano para comparação com os modelos. Note-se que nessa tabela, o ano de 2006 é completado com 256 dias, baseando-se na média do primeiro período monitorado, e o ano de 2012 é completado com 92 dias, baseando-se na média do último período monitorado, o que, evidentemente, pode distorcer as comparações nesses anos. Foram 14 períodos consecutivos monitorados, de setembro de 2006 até o final de setembro de 2012.

Endereço do projeto na página do MDL:

http://cdm.UNFCCC.int/Projects/DB/DNV-CUK1134989999.25/view

Tabela 12 - Dados de reduções na linha de base por período, em $\mathrm{CO}_{2} \mathrm{e}$, para ESTREPaulínia

\begin{tabular}{|c|c|c|c|c|c|c|c|}
\hline \multirow{2}{*}{$\begin{array}{c}\text { Relatório de } \\
\text { Monitoramento } \\
\text { (MR) }\end{array}$} & \multirow[t]{2}{*}{ Data início } & \multirow[t]{2}{*}{ Data fim } & \multirow[t]{2}{*}{ Dias } & $\begin{array}{l}\text { Reduções } \\
\text { na linha de } \\
\text { base }\end{array}$ & \multirow[t]{2}{*}{$\begin{array}{l}\text { Linha } \\
\text { de } \\
\text { base }\end{array}$} & $\begin{array}{c}\text { Total } \\
\text { oxidado }\end{array}$ & $\begin{array}{c}\text { Oxidado } \\
\text { por dia }\end{array}$ \\
\hline & & & & t $\mathrm{CO}_{2} \mathrm{e}$ & & \multicolumn{2}{|c|}{ t $\mathrm{CO}_{2} \mathrm{e}$} \\
\hline MR01 pág.19 & $14 / 09 / 2006$ & $31 / 01 / 2007$ & 140 & $56.438,23$ & $20 \%$ & $70.547,78$ & 503,91 \\
\hline MR02 pág.21 & 01/02/2007 & $31 / 07 / 2007$ & 181 & $82.132,78$ & $20 \%$ & $102.665,97$ & 567,22 \\
\hline MR03 pág.24 & 01/08/2007 & 29/02/2008 & 213 & $113.085,50$ & $20 \%$ & $141.356,88$ & 663,65 \\
\hline MR04 pág.13 & $01 / 03 / 2008$ & $31 / 08 / 2008$ & 184 & $115.937,24$ & $20 \%$ & $144.921,55$ & 787,62 \\
\hline MR05 pág.16 & $01 / 09 / 2008$ & $31 / 01 / 2009$ & 153 & $104.620,68$ & $20 \%$ & $130.775,85$ & 854,74 \\
\hline MR06 pág.14 & $01 / 02 / 2009$ & $30 / 06 / 2009$ & 150 & $112.809,79$ & $20 \%$ & $141.012,23$ & 940,08 \\
\hline MR07 pág.21 & 01/07/2009 & $25 / 02 / 2010$ & 240 & $180.169,98$ & $20 \%$ & $225.212,47$ & 938,39 \\
\hline MR08 pág.28 & $26 / 02 / 2010$ & $31 / 07 / 2010$ & 156 & $187.504,00$ & $20 \%$ & $234.380,00$ & $1.502,44$ \\
\hline MR09 pág.25 & 01/08/2010 & $31 / 10 / 2010$ & 92 & $118.618,00$ & $20 \%$ & $148.272,50$ & $1.611,66$ \\
\hline MR10 pág.26 & $01 / 11 / 2010$ & $31 / 01 / 2011$ & 92 & $119.168,00$ & $20 \%$ & $148.960,00$ & $1.619,13$ \\
\hline MR11 pág.28 & $01 / 02 / 2011$ & $30 / 04 / 2011$ & 89 & $122.467,00$ & $20 \%$ & $153.083,75$ & $1.720,04$ \\
\hline MR12 pág.28 & $01 / 05 / 2011$ & $30 / 11 / 2011$ & 214 & $307.136,00$ & $20 \%$ & $383.920,00$ & $1.794,02$ \\
\hline MR13 pág.26 & $01 / 12 / 2011$ & $31 / 05 / 2012$ & 183 & $278.210,00$ & $20 \%$ & $347.762,50$ & $1.900,34$ \\
\hline MR14 pág.24 & $01 / 06 / 2012$ & $30 / 09 / 2012$ & 122 & $178.133,00$ & $20 \%$ & $222.666,25$ & $1.825,13$ \\
\hline
\end{tabular}


Tabela 13 - Cálculo do metano captado, ou oxidado, no Projeto ESTRE-Paulínia por ano

\begin{tabular}{|c|c|c|c|c|c|c|}
\hline \multirow{2}{*}{ Início } & \multirow{2}{*}{ Fim } & \multirow{2}{*}{ Dias } & \multirow{2}{*}{$\begin{array}{c}\text { Metano } \\
\text { oxidado } \\
\mathrm{t} \mathrm{CO}_{2} \mathrm{e} \\
\end{array}$} & \multirow{2}{*}{ No ano } & \multicolumn{2}{|c|}{ Metano oxidado } \\
\hline & & & & & $\mathrm{tCO}_{2} \mathrm{e}$ & $\mathrm{tCH}_{4}$ \\
\hline \multicolumn{2}{|c|}{ Para completar o ano } & 256 & $129.001,66$ & 2006 & & \\
\hline $14 / 09 / 2006$ & $31 / 12 / 2006$ & 109 & $54.926,49$ & 2000 & $183.928,15$ & $8.158,48$ \\
\hline 01/01/2007 & $31 / 01 / 2007$ & 31 & $15.621,29$ & \multirow{3}{*}{2007} & \multirow{3}{*}{$219.825,30$} & \multirow{3}{*}{$10.467,87$} \\
\hline 01/02/2007 & $31 / 07 / 2007$ & 181 & $102.665,97$ & & & \\
\hline 01/08/2007 & $31 / 12 / 2007$ & 153 & $101.538,04$ & & & \\
\hline 01/01/2008 & $29 / 02 / 2008$ & 60 & $39.818,84$ & \multirow{3}{*}{2008} & \multirow{3}{*}{$289.019,17$} & \multirow{3}{*}{$13.762,82$} \\
\hline 01/03/2008 & $31 / 08 / 2008$ & 184 & $144.921,55$ & & & \\
\hline 01/09/2008 & $31 / 12 / 2008$ & 122 & $104.278,78$ & & & \\
\hline 01/01/2009 & $31 / 01 / 2009$ & 31 & $26.497,07$ & \multirow{3}{*}{2009} & \multirow{3}{*}{$340.172,19$} & \multirow{3}{*}{$16.198,68$} \\
\hline 01/02/2009 & $30 / 06 / 2009$ & 150 & $141.012,23$ & & & \\
\hline 01/07/2009 & $31 / 12 / 2009$ & 184 & $172.662,89$ & & & \\
\hline 01/01/2010 & $25 / 02 / 2010$ & 56 & $52.549,58$ & \multirow{4}{*}{2010} & \multirow{4}{*}{$533.969,03$} & \multirow{4}{*}{$25.427,10$} \\
\hline $26 / 02 / 2010$ & $31 / 07 / 2010$ & 156 & $234.380,00$ & & & \\
\hline 01/08/2010 & $31 / 10 / 2010$ & 92 & $148.272,50$ & & & \\
\hline $01 / 11 / 2010$ & $31 / 12 / 2010$ & 61 & $98.766,96$ & & & \\
\hline $01 / 01 / 2011$ & $31 / 01 / 2011$ & 31 & $50.193,04$ & \multirow{4}{*}{2011} & \multirow{4}{*}{$646.107,38$} & \multirow{4}{*}{$30.767,0$} \\
\hline $01 / 02 / 2011$ & $30 / 04 / 2011$ & 89 & $153.083,75$ & & & \\
\hline $01 / 05 / 2011$ & $30 / 11 / 2011$ & 214 & $383.920,00$ & & & \\
\hline $01 / 12 / 2011$ & $31 / 12 / 2011$ & 31 & $58.910,59$ & & & \\
\hline 01/01/2012 & $31 / 05 / 2012$ & 152 & $288.851,91$ & \multirow{3}{*}{2012} & \multirow{3}{*}{$679.430,42$} & \multirow{3}{*}{$32.353,83$} \\
\hline 01/06/2012 & $30 / 09 / 2012$ & 122 & $222.666,25$ & & & \\
\hline Para comp & etaro ano & 92 & $167.912,25$ & & & \\
\hline
\end{tabular}

\subsubsection{Caieiras}

Os valores das reduções na linha de base relativos ao metano são apresentados por mês, em $\mathrm{CO}_{2} \mathrm{e}$, em planilhas auxiliares apresentadas junto aos relatórios de monitoramento, na seção full history de cada um dos períodos de monitoramento, ou seja, as reduções de metano com o desconto de linha de base de $20 \%$ incluído. Foram sete os períodos consecutivos monitorados, de fevereiro de 2007 até o final de setembro de 2012. A Tabela 14 apresenta tanto os valores das reduções na linha de base de metano em $\mathrm{CO}_{2}$ e, quanto o metano efetivamente oxidado, sem o desconto. Para a obtenção dos totais anuais de oxidação de metano, de modo a permitir comparação com os modelos, foram feitas as seguintes adições: o mês de janeiro de 2007, feito igual ao mês de fevereiro, e os meses de outubro a dezembro 
de 2012, feitos iguais ao mês de setembro precedente. Tais acréscimos podem, evidentemente, distorcer as comparações nesses anos.

Endereço do projeto na página do MDL:

http://cdm.UNFCCC.int/Projects/DB/DNV-CUK1134509951.62/view

Tabela 14 - Dados de reduções na linha de base por período, em $\mathrm{CO}_{2} \mathrm{e}$, para Caieiras

\begin{tabular}{|c|c|c|c|c|c|}
\hline \multirow{2}{*}{ Ano } & \multirow{2}{*}{ Mês } & $\begin{array}{l}\text { Reduções na linha } \\
\text { de base }\end{array}$ & \multirow{2}{*}{$\begin{array}{l}\text { Linha } \\
\text { de base }\end{array}$} & \multicolumn{2}{|c|}{ Metano oxidado } \\
\hline & & $\mathrm{t} \mathrm{CO}_{2} \mathrm{e}$ & & $\mathrm{t} \mathrm{CO}_{2} \mathrm{e}$ & $\mathrm{t} \mathrm{CH}_{4}$ \\
\hline \multirow{12}{*}{2007} & Jan & \multicolumn{3}{|c|}{ Para completar o ano } & 145,04 \\
\hline & Fev & $2.436,65$ & $20 \%$ & $3.045,81$ & 145,04 \\
\hline & Mar & $7.287,94$ & $20 \%$ & $9.109,92$ & 433,81 \\
\hline & Abr & $7.397,27$ & $20 \%$ & $9.246,59$ & 440,31 \\
\hline & Mai & $10.357,88$ & $20 \%$ & $12.947,35$ & 616,54 \\
\hline & Jun & $10.870,38$ & $20 \%$ & $13.587,98$ & 647,05 \\
\hline & Jul & $16.134,75$ & $20 \%$ & $20.168,44$ & 960,40 \\
\hline & Ago & $18.167,10$ & $20 \%$ & $22.708,88$ & $1.081,38$ \\
\hline & Set & $14.603,32$ & $20 \%$ & $18.254,14$ & 869,24 \\
\hline & Out & $15.829,74$ & $20 \%$ & $19.787,18$ & 942,25 \\
\hline & Nov & $14.557,06$ & $20 \%$ & $18.196,32$ & 866,49 \\
\hline & Dez & $19.126,54$ & $20 \%$ & $23.908,18$ & $1.138,48$ \\
\hline & & $136.768,63$ & & $170.960,79$ & $8.286,03$ \\
\hline \multirow{12}{*}{2008} & Jan & $25.075,10$ & $20 \%$ & $31.343,87$ & $1.492,57$ \\
\hline & Fev & $14.531,67$ & $20 \%$ & $18.164,58$ & 864,98 \\
\hline & Mar & $27.126,88$ & $20 \%$ & $33.908,60$ & $1.614,70$ \\
\hline & Abr & $30.207,00$ & $20 \%$ & $37.758,75$ & $1.798,04$ \\
\hline & Mai & $30.426,29$ & $20 \%$ & $38.032,86$ & $1.811,09$ \\
\hline & Jun & $32.690,16$ & $20 \%$ & $40.862,70$ & $1.945,84$ \\
\hline & Jul & $33.703,78$ & $20 \%$ & $42.129,73$ & $2.006,18$ \\
\hline & Ago & $32.723,25$ & $20 \%$ & $40.904,06$ & $1.947,81$ \\
\hline & Set & $33.007,30$ & $20 \%$ & $41.259,12$ & $1.964,72$ \\
\hline & Out & $21.697,45$ & $20 \%$ & $27.121,82$ & $1.291,52$ \\
\hline & Nov & $11.247,89$ & $20 \%$ & $14.059,87$ & 669,52 \\
\hline & Dez & $71.521,00$ & $20 \%$ & $89.401,25$ & $4.257,20$ \\
\hline \multicolumn{2}{|c|}{ Total } & $363.957,77$ & & $454.947,21$ & $21.664,15$ \\
\hline
\end{tabular}


Tabela 14 (continuação)

\begin{tabular}{|c|c|c|c|c|c|}
\hline \multirow{2}{*}{ Ano } & \multirow{2}{*}{ Mês } & \multirow{2}{*}{$\begin{array}{c}\begin{array}{c}\text { Reduções na linha } \\
\text { de base }\end{array} \\
\mathrm{t} \mathrm{CO}_{2} \mathrm{e}\end{array}$} & \multirow{2}{*}{$\begin{array}{l}\text { Linha } \\
\text { de base }\end{array}$} & \multicolumn{2}{|c|}{ Metano oxidado } \\
\hline & & & & $\mathrm{tCO}_{2} \mathrm{e}$ & t $\mathrm{CH}_{4}$ \\
\hline \multirow{12}{*}{2009} & Jan & $37.182,98$ & $20 \%$ & $46.478,72$ & $2.213,27$ \\
\hline & Fev & $34.993,90$ & $20 \%$ & $43.742,37$ & $2.082,97$ \\
\hline & Mar & $38.191,30$ & $20 \%$ & $47.739,13$ & $2.273,29$ \\
\hline & Abr & $36.460,47$ & $20 \%$ & $45.575,58$ & $2.170,27$ \\
\hline & Mai & $42.092,90$ & $20 \%$ & $52.616,13$ & $2.505,53$ \\
\hline & Jun & $42.434,78$ & $20 \%$ & $53.043,48$ & $2.525,88$ \\
\hline & Jul & $42.406,85$ & $20 \%$ & $53.008,57$ & $2.524,22$ \\
\hline & Ago & $44.472,67$ & $20 \%$ & $55.590,83$ & $2.647,18$ \\
\hline & Set & $42.241,58$ & $20 \%$ & $52.801,98$ & $2.514,38$ \\
\hline & Out & $49.284,02$ & $20 \%$ & $61.605,02$ & $2.933,57$ \\
\hline & Nov & $49.690,20$ & $20 \%$ & $62.112,75$ & $2.957,75$ \\
\hline & Dez & $50.900,72$ & $20 \%$ & $63.625,91$ & $3.029,81$ \\
\hline \multicolumn{2}{|c|}{ Total } & $510.352,38$ & & $637.940,47$ & $30.378,12$ \\
\hline \multirow{12}{*}{2010} & Jan & $50.712,99$ & $20 \%$ & $63.391,24$ & $3.018,63$ \\
\hline & Fev & $45.812,60$ & $20 \%$ & $57.265,75$ & $2.726,94$ \\
\hline & Mar & $45.758,93$ & $20 \%$ & $57.198,66$ & $2.723,75$ \\
\hline & Abr & $50.105,04$ & $20 \%$ & $62.631,31$ & $2.982,44$ \\
\hline & Mai & $51.053,69$ & $20 \%$ & $63.817,11$ & $3.038,91$ \\
\hline & Jun & $48.920,17$ & $20 \%$ & $61.150,21$ & $2.911,91$ \\
\hline & Jul & $53.793,04$ & $20 \%$ & $67.241,30$ & $3.201,97$ \\
\hline & Ago & $56.016,15$ & $20 \%$ & $70.020,19$ & $3.334,29$ \\
\hline & Set & $50.086,20$ & $20 \%$ & $62.607,75$ & $2.981,32$ \\
\hline & Out & $50.607,35$ & $20 \%$ & $63.259,19$ & $3.012,34$ \\
\hline & Nov & $44.793,20$ & $20 \%$ & $55.991,50$ & $2.666,26$ \\
\hline & Dez & $38.179,01$ & $20 \%$ & $47.723,76$ & $2.272,56$ \\
\hline \multicolumn{2}{|c|}{ Total } & $585.838,37$ & & $732.297,96$ & $34.871,33$ \\
\hline \multirow{12}{*}{2011} & Jan & $39.530,12$ & $20 \%$ & $49.412,65$ & $2.352,98$ \\
\hline & Fev & $33.509,50$ & $20 \%$ & $41.886,87$ & $1.994,61$ \\
\hline & Mar & $44.986,20$ & $20 \%$ & $56.232,74$ & $2.677,75$ \\
\hline & Abr & $49.361,17$ & $20 \%$ & $61.701,47$ & $2.938,17$ \\
\hline & Mai & $56.521,38$ & $20 \%$ & $70.651,72$ & $3.364,37$ \\
\hline & Jun & $55.595,32$ & $20 \%$ & $69.494,15$ & $3.309,25$ \\
\hline & Jul & $63.386,27$ & $20 \%$ & $79.232,84$ & $3.772,99$ \\
\hline & Ago & $58.728,20$ & $20 \%$ & $73.410,25$ & $3.495,73$ \\
\hline & Set & $65.811,28$ & $20 \%$ & $82.264,10$ & $3.917,34$ \\
\hline & Out & $74.523,24$ & $20 \%$ & $93.154,05$ & $4.435,91$ \\
\hline & Nov & $68.321,01$ & $20 \%$ & $85.401,27$ & $4.066,73$ \\
\hline & Dez & $78.765,20$ & $20 \%$ & $98.456,50$ & $4.688,40$ \\
\hline \multicolumn{2}{|c|}{ Total } & $689.038,88$ & & $861.298,60$ & $41.014,22$ \\
\hline
\end{tabular}


Tabela 14 (continuação)

\begin{tabular}{|c|c|c|c|c|c|}
\hline \multirow{2}{*}{ Ano } & \multirow{2}{*}{ Mês } & \multirow{2}{*}{$\begin{array}{c}\begin{array}{c}\text { Reduções na linha } \\
\text { de base }\end{array} \\
\text { t } \mathrm{CO}_{2} \mathrm{e}\end{array}$} & \multirow{2}{*}{$\begin{array}{l}\text { Linha } \\
\text { de base }\end{array}$} & \multicolumn{2}{|c|}{ Metano oxidado } \\
\hline & & & & $\mathrm{tCO}_{2} \mathrm{e}$ & $\mathrm{t} \mathrm{CH}_{4}$ \\
\hline \multirow{12}{*}{2012} & Jan & $74.135,75$ & $20 \%$ & $92.669,68$ & $4.412,84$ \\
\hline & Fev & $75.997,21$ & $20 \%$ & $94.996,51$ & $4.523,64$ \\
\hline & Mar & $85.125,79$ & $20 \%$ & $106.407,24$ & $5.067,01$ \\
\hline & Abr & $80.819,38$ & $20 \%$ & $101.024,22$ & $4.810,68$ \\
\hline & Mai & $94.571,06$ & $20 \%$ & $118.213,83$ & $5.629,23$ \\
\hline & Jun & $92.668,37$ & $20 \%$ & $115.835,47$ & $5.515,97$ \\
\hline & Jul & $90.386,68$ & $20 \%$ & $112.983,35$ & $5.380,16$ \\
\hline & Ago & $92.206,67$ & $20 \%$ & $115.258,34$ & $5.488,49$ \\
\hline & Set & $80.165,96$ & $20 \%$ & $100.207,45$ & $4.771,78$ \\
\hline & Out & \multicolumn{3}{|c|}{ Para completar o ano } & $4.771,78$ \\
\hline & Nov & \multicolumn{3}{|c|}{ Para completar o ano } & $4.771,78$ \\
\hline & Dez & \multicolumn{3}{|c|}{ Para completar o ano } & $4.771,78$ \\
\hline \multicolumn{2}{|c|}{ Total } & $766.076,87$ & & $957.596,09$ & $59.915,16$ \\
\hline
\end{tabular}

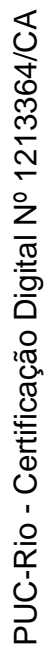




\section{Resultados e discussão}

Após os valores do metano extraído terem sido recuperados a partir dos relatórios de monitoramento finais, as eficiências de extração foram calculadas em bases anuais: metano recuperado dividido pelo metano gerado, segundo cada modelo (Equação 2). Os modelos fornecem valores para os anos-calendário, enquanto os períodos de monitoramento, que são ininterruptos, podem não começar ou não terminar no início ou no fim de um ano, respectivamente. Nesses casos e apenas quando necessário para equalizar a comparação, os valores de metano recuperado referentes a anos incompletos foram aumentados proporcionalmente aos dias faltantes, com base em critérios que variaram conforme o caso. Desse modo, para Adrianópolis foram adicionados 73 dias de emissões no início de 2007, com base na média diária do ano, a fim de completá-lo; para Bandeirantes, 122 dias foram adicionados no final de 2012, com base na média diária do último relatório de monitoramento; para ESTRE-Paulínia, 256 dias foram adicionados no início de 2006 com base no primeiro relatório de monitoramento e 92 dias no final de 2012, com base no último relatório; para Caieiras, o primeiro mês de 2007 foi feito igual ao mês de fevereiro e os três últimos de 2012 foram feitos iguais ao mês de setembro, dos respectivos anos. Por isso, esses anos alterados podem ser vistos com alguma reserva quando da análise final.

A fim de permitir a comparação entre os modelos utilizados nas diferentes oportunidades para cada aterro, os seguintes cuidados foram tomados:

- Todos os cálculos foram refeitos, a fim de se chegar aos valores de emissões expressos no $P D D$, seguindo os parâmetros indicados. Nos primeiros $P D D$ s não havia planilha disponível, exceto para ESTREPaulínia; para os segundos, planilhas estavam disponíveis no site do MDL. Para se chegar aos resultados apresentados no PDD, algumas correções nos parâmetros foram necessárias, conforme indicado por 
retroanálise. Em um caso foi encontrado um duplo desconto relacionado ao fator de oxidação ${ }^{32}$;

- No primeiro $P D D$, não foi utilizado nenhum fator de oxidação. Como isso pode ser adicionado simplesmente no final, esse fator é aqui usado em todos os modelos para comparação final;

- Somente no modelo CDM Tool há um fator de incerteza. Antes de sua versão 06.0.0 de 25 de novembro de 2011, esse fator foi de 0,9 e, em seguida, mudou para 0,75. Esse fator de incerteza não existia nos primeiros PDDs usando os modelos do IPCC (1997) ou do IPCC (2000). Para efeito de comparação com os outros, o modelo CDM Tool é apresentado aqui com três fatores de incerteza: 1, 0,9 e 0,75;

- Como os segundos PDDs dão valores reais para as quantidades de resíduos depositados nos sete anos anteriores, os valores atualizados são usados aqui para todos os modelos.

Os valores de $k$ e $L_{0}$ utilizados para os aterros sanitários nos primeiros $P D D$ s estão apresentados na Tabela 15, juntamente com os valores correspondentes sugeridos pelo IPCC (2006) para resíduos em massa, que dependem dos parâmetros revelados nos segundos $P D D$ s.

Tabela 15 - Constante de decaimento e potencial de metano usados nos primeiros PDDs

\begin{tabular}{|c|c|c|c|c|c|c|c|}
\hline \multirow{3}{*}{ Aterro } & \multicolumn{7}{|c|}{$P D D-1$} \\
\hline & \multicolumn{3}{|c|}{$k\left(a n o^{-1}\right)$} & \multicolumn{3}{|c|}{$\mathrm{L}_{0}\left(\mathrm{~m}^{3} \mathrm{CH}_{4} / \mathrm{t}\right.$ resíduo $)$} & \multirow[t]{2}{*}{ Modelo } \\
\hline & $P D D$ & $\begin{array}{l}\text { Retro- } \\
\text { análise }\end{array}$ & $\begin{array}{l}I P C C \\
2006 \\
\end{array}$ & $P D D$ & $\begin{array}{l}\text { Retro- } \\
\text { análise }\end{array}$ & $\begin{array}{l}\text { IPCC } \\
2006\end{array}$ & \\
\hline Adrianópolis & 0,1 & 0,1 & 0,17 & 65,67 & 117,14 & 58,37 & IPCC 1997 \\
\hline Bandeirantes & 0,105 & 0,102 & 0,17 & 76,73 & 84,10 & 73,01 & IPCC 1997 \\
\hline $\begin{array}{l}\text { ESTRE- } \\
\text { Paulínia* }\end{array}$ & 0,09 & 0,09 & 0,17 & 140,00 & 140,00 & 68,71 & IPCC 1997 \\
\hline Caieiras* & 0,08 & 0,08 & 0,09 & 116,00 & 115,78 & 75,43 & IPCC 2000 \\
\hline
\end{tabular}

Nos segundos $P D D$ s, os parâmetros $k_{j}, D O C_{j}$ são valores default do IPCC (2006), considerando que Caieiras tem uma condição de clima temperado-úmido e

${ }^{32}$ ESTRE-Paulínia, PDD-2, em sua planilha anexa publicada no site do MDL denominada PDD2_ESTRE_Paulínia_CER sheet_165.xlsx, aba "Baseline emissions", linha 320, coluna R e seguintes. 
os outros têm uma condição tropical-úmido. A composição dos resíduos para cada aterro é mostrada na Tabela 16. Todos têm a sua própria composição de resíduos, exceto Caieiras que adotou valores default do IPCC (2006) para a América do Sul.

Tabela 16 - Frações de resíduos utilizadas nos segundos $P D D$ s

\begin{tabular}{lccccc}
\hline \multirow{2}{*}{ Aterro } & \multicolumn{5}{c}{ PDD-2 } \\
\cline { 2 - 6 } & $\begin{array}{c}\text { Madeiras e } \\
\text { produtos de } \\
\text { madeira }\end{array}$ & $\begin{array}{c}\text { Celulose, papel } \\
\text { e papelão }\end{array}$ & $\begin{array}{c}\text { Alimentos, restos } \\
\text { alimentares, } \\
\text { bebidas e tabaco }\end{array}$ & Têxteis & $\begin{array}{c}\text { Restos de } \\
\text { jardins, quintais } \\
\text { e parques }\end{array}$ \\
\hline Adrianópolis & $0,8 \%$ & $18,0 \%$ & $48,7 \%$ & $3,9 \%$ & $0,0 \%$ \\
Bandeirantes & $0,7 \%$ & $12,3 \%$ & $60,6 \%$ & $3,1 \%$ & $3,2 \%$ \\
ESTRE-Paulínia & $1,2 \%$ & $17,4 \%$ & $41,6 \%$ & $4,3 \%$ & $0,0 \%$ \\
Caieiras & $4,7 \%$ & $17,1 \%$ & $44,9 \%$ & $2,6 \%$ & $0,0 \%$ \\
\hline
\end{tabular}

Na Tabela 17 há um resumo das informações dos $P D D$ s e relatórios de monitoramento, incluindo a recuperação de metano para cada aterro.

Tabela 17 - Informações gerais dos aterros estudados (dos PDDs e relatórios de monitoramento)

\begin{tabular}{lcccccr}
\hline \multicolumn{1}{c}{ Aterro } & Início & $\begin{array}{c}\text { Resíduos } \\
\text { depositados } \\
\text { até2012 } \\
(t)\end{array}$ & $\begin{array}{c}\text { Eficiência de } \\
\text { extração } \\
\text { projetada no } \\
P D D-1\end{array}$ & $\begin{array}{c}\text { Número de } \\
\text { relatórios de } \\
\text { monitoramento }\end{array}$ & $\begin{array}{c}\text { Período } \\
\text { monitorado }\end{array}$ & $\begin{array}{c}\text { Metano } \\
\text { recuperado } \\
(t)\end{array}$ \\
\hline Adrianópolis & 2003 & 7.780 .010 & $85 \%$ & 6 & 6 anos & 26.292 \\
Bandeirantes & 1979 & 37.226 .873 & $80 \%$ & 18 & 9 anos & 232.075 \\
ESTRE-Paulínia & 2000 & 13.512 .504 & $80 \%$ & 14 & 7 anos & 123.460 \\
Caieiras & 2002 & 20.234 .148 & $80 \%{ }^{*}$ & 7 & 6 anos & 180.365 \\
\hline
\end{tabular}

* Apenas para o ano de 2007, a eficiência de extração foi estimada no $P D D$ em $70 \%$.

Com as quantidades anuais de metano recuperado e a estimativa segundo cada modelo representativo, as eficiências anuais foram calculadas para cada ano dos períodos monitorados. Os resultados estão na Figura 8, para Adrianópolis, na Figura 9, para Bandeirantes, na Figura 10, para ESTRE-Paulínia, e na Figura 11, para Caieiras.

O primeiro modelo em cada figura é o usado no $P D D-1$ de cada projeto, o do IPCC (1997), exceto Caieiras, que usa o do IPCC (2000); o segundo modelo é o do IPCC (2000) corrigido com o fator A' e atraso de seis meses. Nesses dois modelos, a constante de decaimento $k$ e o potencial de geração de metano $L_{0}$ são os usados no $P D D-1$, depois da verificação feita neste trabalho. 
O terceiro modelo é o do IPCC (2006) usando a opção massa, com o atraso default de seis meses, com a constante de decaimento de acordo com o default para as condições de clima/umidade de cada localidade e com o potencial de geração de metano de acordo com as frações de resíduos indicadas no $P D D-2$ de cada projeto, pois acabam revelando o verdadeiro perfil do material que irá se decompor.

O quarto modelo é o indicado pelo CDM Tool, conforme atualmente publicado, onde existe o erro de fórmula indicado neste trabalho, e também sem considerar o atraso existente na decomposição dos resíduos, conforme indica a metodologia mais detalhada do IPCC (2006). Aqui não se coloca o fator de incerteza $\varphi$ para que se possa avaliá-lo separadamente.

O quinto modelo é o CDM Tool com as correções propostas neste trabalho, ou seja, acerto na fórmula e considerando emissão apenas no ano seguinte ao da disposição. Também aqui ainda não se considera o fator de incerteza $\varphi$.

O sexto e o sétimo modelos são idênticos ao quinto, com a única diferença de usarem os fatores de incerteza $\varphi=0,9$ e $\varphi=0,75$, respectivamente, que entram multiplicando o resultado no final. O primeiro valor foi inicialmente indicado nas primeiras versões do CDM Tool, posteriormente alterado para o segundo valor, que, na ausência de incertezas específicas para diversos parâmetros da equação, passa a ser o default.

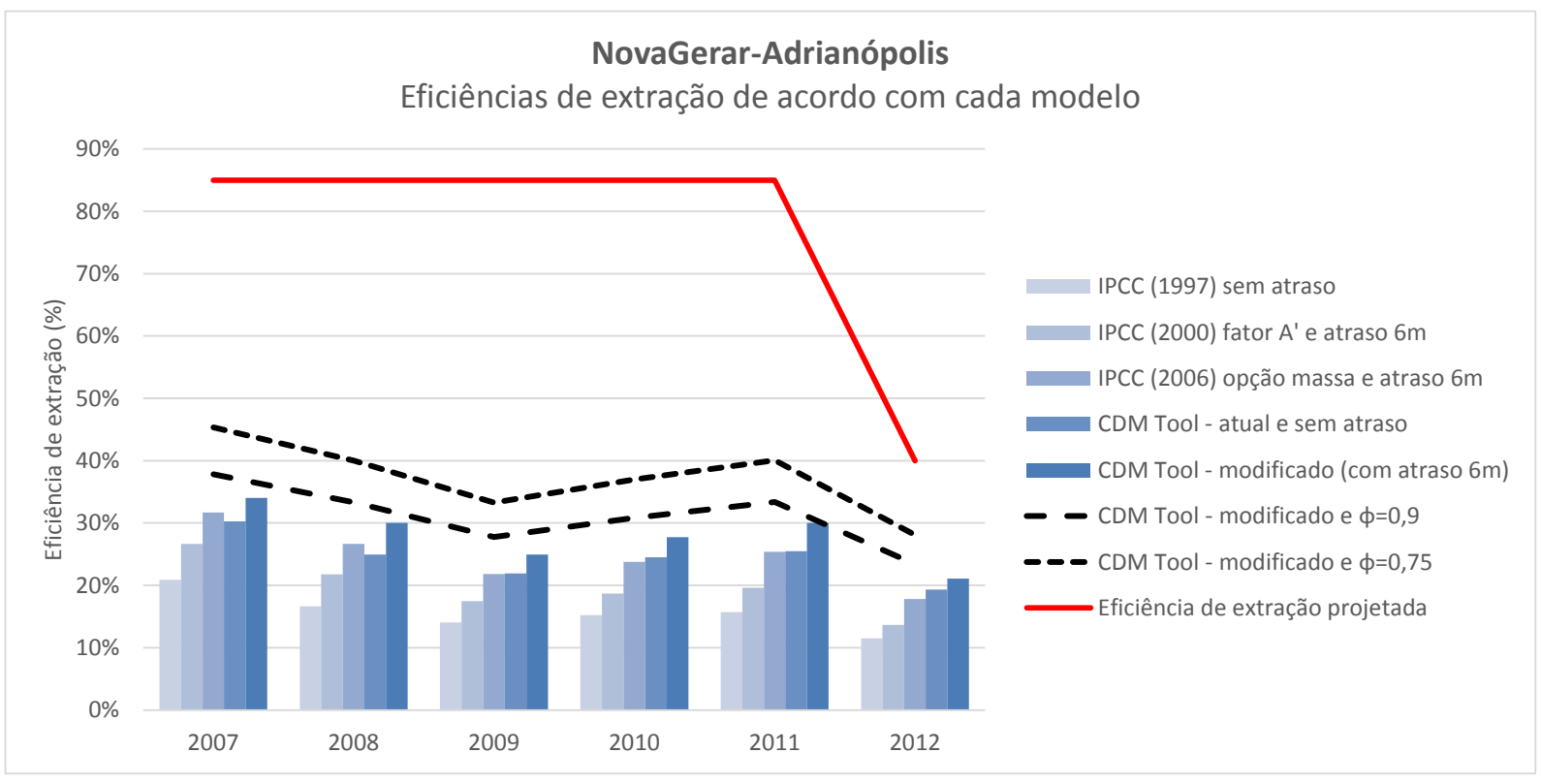

Figura 8 - Eficiências de extração para cada modelo - Adrianópolis 


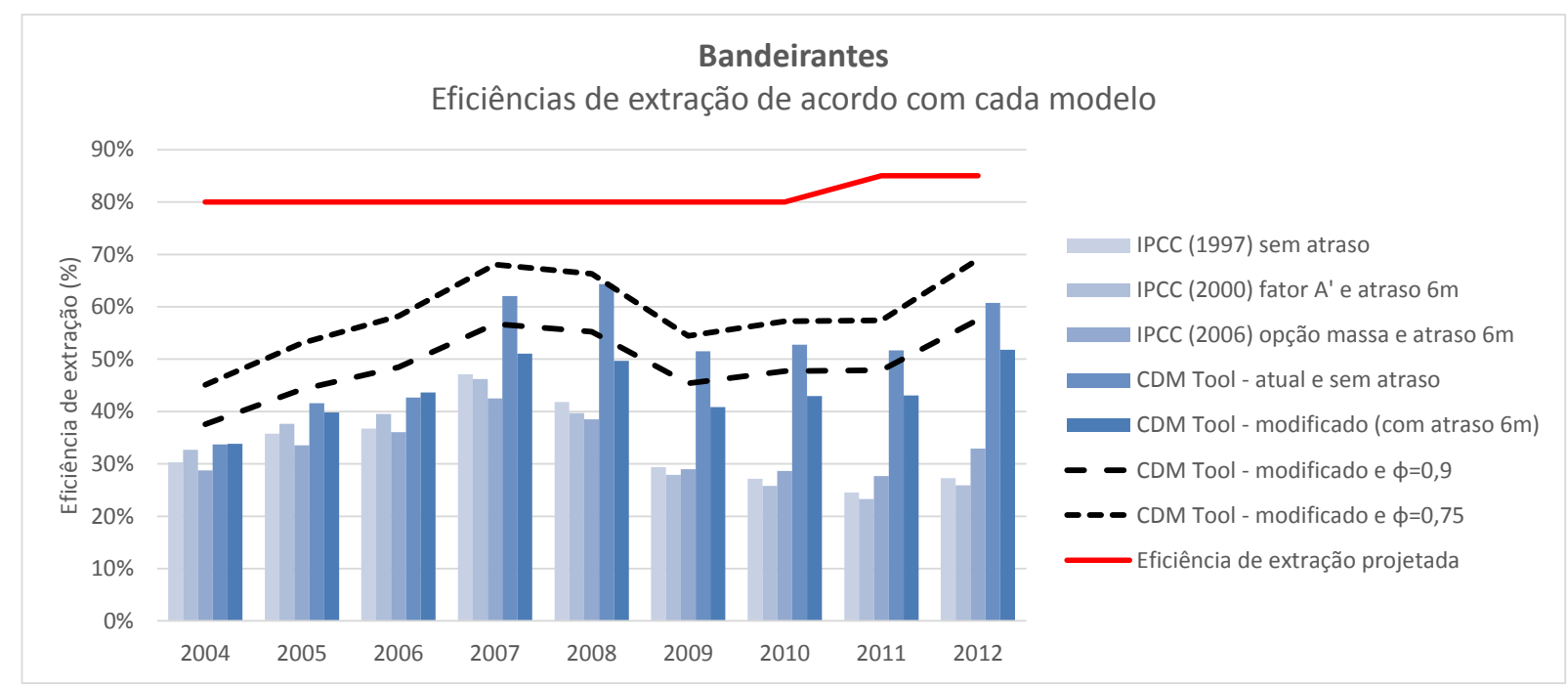

Figura 9 - Eficiências de extração para cada modelo - Bandeirantes

\section{ESTRE-Paulínia}

Eficiências de extração de acordo com cada modelo

$$
120 \%
$$

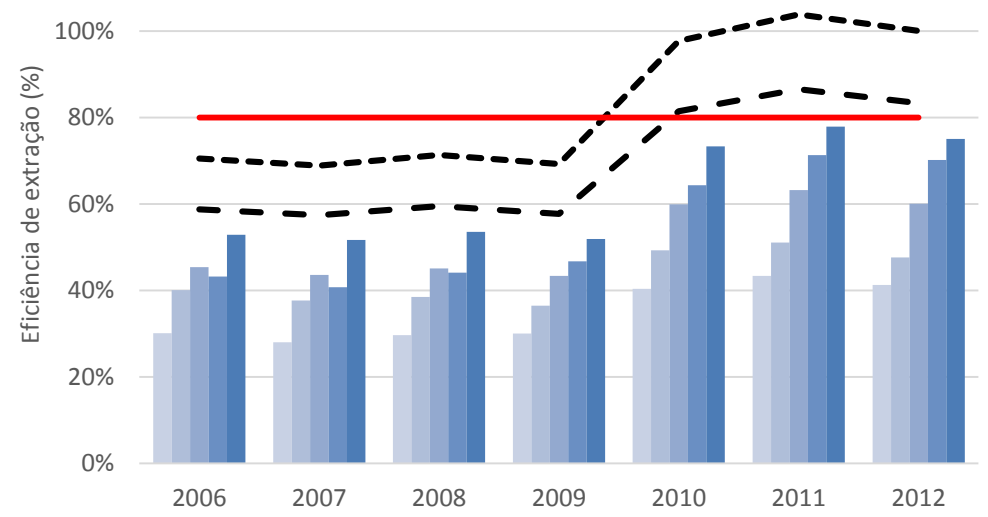

IPCC (1997) sem atraso

IPCC (2000) fator A' e atraso $6 \mathrm{~m}$

IPCC (2006) opção massa e atraso $6 \mathrm{~m}$

CDM Tool - atual e sem atraso

CDM Tool - modificado (com atraso 6m)

- CDM Tool - modificado e $\phi=0,9$

- - CDM Tool - modificado e $\phi=075$

—Eficiência de extração projetada

Figura 10 - Eficiências de extração para cada modelo - ESTRE-Paulínia 


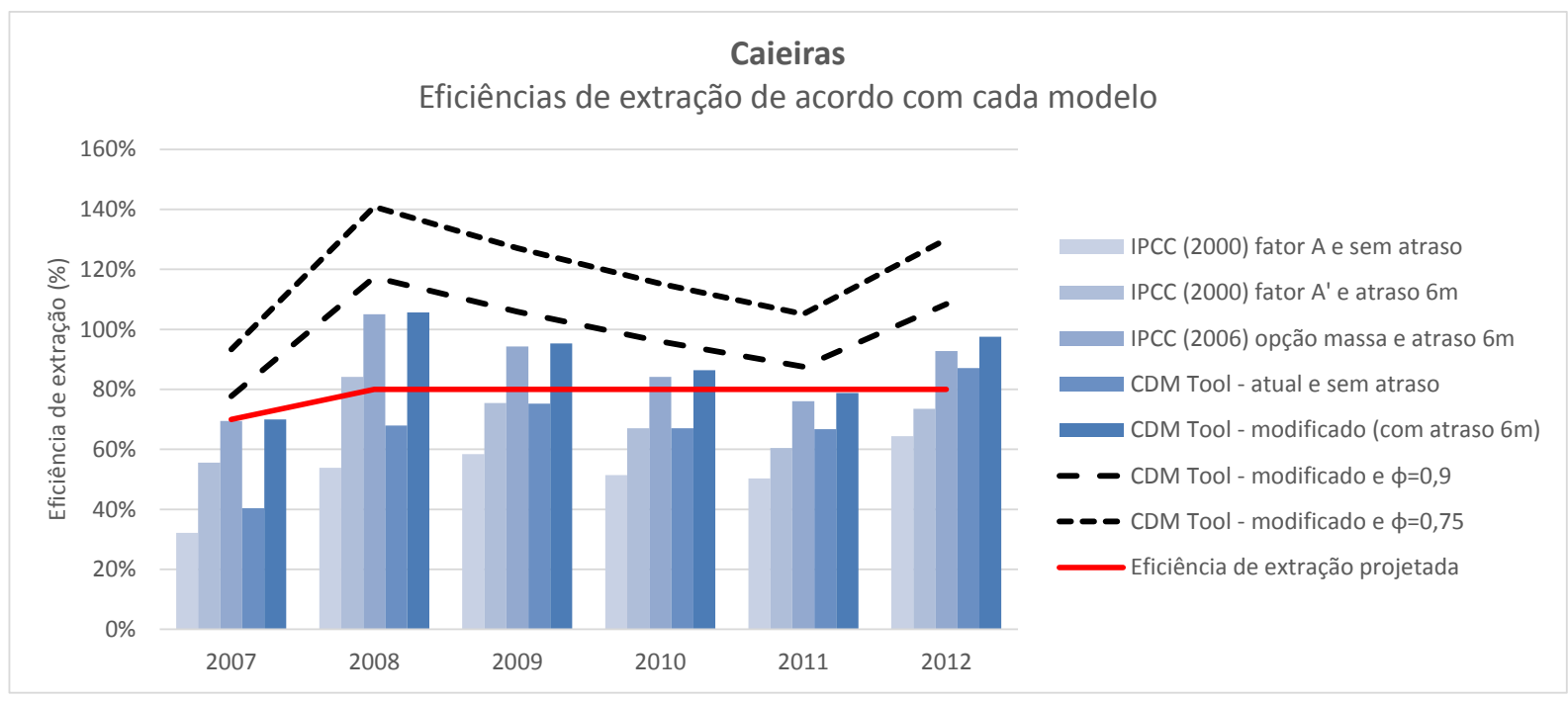

Figura 11 - Eficiências de extração para cada modelo - Caieiras

A Tabela 18 apresenta esses resultados de forma sintética, com a indicação dos valores anuais máximos, mínimos e médios das eficiências de extração para cada modelo chave.

Tabela 18 - Eficiências de extração (valores máximo, mínimo e médios, dentro do período de observação) para cada aterro considerado e modelo

\begin{tabular}{|c|c|c|c|c|c|c|c|c|}
\hline \multirow[t]{2}{*}{ Aterro } & \multirow[t]{2}{*}{ 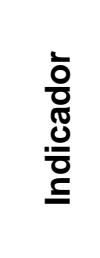 } & \multirow{2}{*}{$\frac{*}{5}$} & \multirow{2}{*}{ 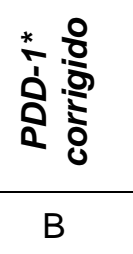 } & \multirow{2}{*}{ 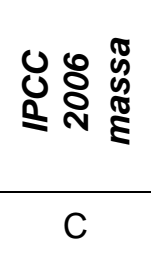 } & \multirow{2}{*}{ 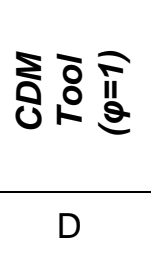 } & \multicolumn{2}{|c|}{ ชิ } & \multirow{2}{*}{ 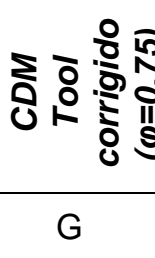 } \\
\hline & & & & & & $\mathrm{E}$ & $\mathrm{F}$ & \\
\hline \multirow{3}{*}{ Adrianópolis } & Máx & $21 \%$ & $27 \%$ & $32 \%$ & $30 \%$ & $34 \%$ & $38 \%$ & $45 \%$ \\
\hline & Mín & $12 \%$ & $14 \%$ & $18 \%$ & $19 \%$ & $21 \%$ & $23 \%$ & $28 \%$ \\
\hline & Méd & $16 \%$ & $20 \%$ & $25 \%$ & $24 \%$ & $28 \%$ & $31 \%$ & $37 \%$ \\
\hline \multirow{3}{*}{ Bandeirantes } & Máx & $47 \%$ & $46 \%$ & $43 \%$ & $64 \%$ & $52 \%$ & $58 \%$ & $69 \%$ \\
\hline & Mín & $25 \%$ & $23 \%$ & $28 \%$ & $51 \%$ & $41 \%$ & $45 \%$ & $54 \%$ \\
\hline & Méd & $33 \%$ & $31 \%$ & $33 \%$ & $57 \%$ & $47 \%$ & $52 \%$ & $62 \%$ \\
\hline \multirow{3}{*}{$\begin{array}{l}\text { ESTRE- } \\
\text { Paulínia }\end{array}$} & Máx & $43 \%$ & $51 \%$ & $63 \%$ & $71 \%$ & $78 \%$ & $87 \%$ & $104 \%$ \\
\hline & Mín & $28 \%$ & $36 \%$ & $43 \%$ & $41 \%$ & $52 \%$ & $57 \%$ & $69 \%$ \\
\hline & Méd & $35 \%$ & $43 \%$ & $53 \%$ & $56 \%$ & $64 \%$ & $71 \%$ & $85 \%$ \\
\hline \multirow{3}{*}{ Caieiras } & Máx & $64 \%$ & $84 \%$ & $105 \%$ & $87 \%$ & $106 \%$ & $117 \%$ & $141 \%$ \\
\hline & Mín & $32 \%$ & $56 \%$ & $69 \%$ & $40 \%$ & $70 \%$ & $78 \%$ & $93 \%$ \\
\hline & Méd & $52 \%$ & $69 \%$ & $87 \%$ & $67 \%$ & $89 \%$ & $99 \%$ & $119 \%$ \\
\hline
\end{tabular}

* Modelos considerados no PDD1 para Adrianópolis, Bandeirantes e ESTRE-Paulínia - IPCC (1997);

Caieiras - IPCC (2000). Todos usam o máximo de emissão desde o ano de deposição. 
Os resultados da Tabela 18 mostram uma superestimação do metano nos primeiros $P D D s$ - coluna $\mathrm{A}$ - que apresentam os menores valores. Isso pode ser devido a dois motivos: primeiro, por causa do modelo usado, conforme discutido antes; segundo, por causa de valores altos para $L_{0}$. Esse parâmetro, potencial de geração de metano, conforme mostrado na Tabela 15, é mais alto em relação ao default do IPCC (2006), ou mais ainda quanto ao proposto por Themelis e Ulloa (2007), quando afirmam que uma geração de metano de cerca de $50 \mathrm{~m}^{3} \mathrm{CH}_{4} / \mathrm{t}$ RSU é conservadora. Note-se que se o fator de oxidação de $10 \%$ não fosse utilizado para esta comparação, as eficiências seriam ainda menores. A correção do primeiro modelo dá estimativas mais baixas e uma maior eficiência, conforme mostra a coluna B. Se fosse usado o modelo do IPCC (2006) na opção massa - coluna C as eficiências seriam ainda melhores, exceto para Bandeirantes.

Nos segundos $P D D$ s, a abordagem das frações dos resíduos é usada. O modelo CDM Tool atual mas sem fator de incerteza - coluna D - já traz melhoras de eficiências em relação aos primeiros $P D D$ s - coluna A - ou sua correção coluna B - exceto em Caieiras. A coluna D pode também ser comparada ao modelo do IPCC (2006) na opção massa - coluna $\mathrm{C}$ - havendo melhora em dois casos Bandeirantes e ESTRE-Paulínia - mas piora em Caieiras. O caso específico de Caieiras será analisado mais à frente.

Se o modelo da coluna D é substituído por sua correção - coluna $\mathrm{E}$ - as melhoras em relação às colunas $\mathrm{A}$ e $\mathrm{B}$ valem para todos os aterros. Mas a comparação da coluna E com a coluna D indica uma redução de eficiência no aterro Bandeirantes. Deve-se lembrar que as variações de eficiência do modelo CDM Tool corrigido dependem do histórico de disposição de resíduos, como foi dito antes. De qualquer modo, as previsões de $80 \%$ - 85\% para a eficiência de captação de biogás parecem ser elevadas em relação ao constatado neste trabalho. As Figuras 12, 13, 14 e 15 ilustram a relação da série de disposição de resíduos com o resultado da correção do CDM Tool, para os quatro aterros analisados. Apenas no caso do Bandeirantes, que encerrou o recebimento em 2007, há uma flutuação de resultados antes desse ano, passando depois a emissões consistentemente maiores no modelo corrigido. 


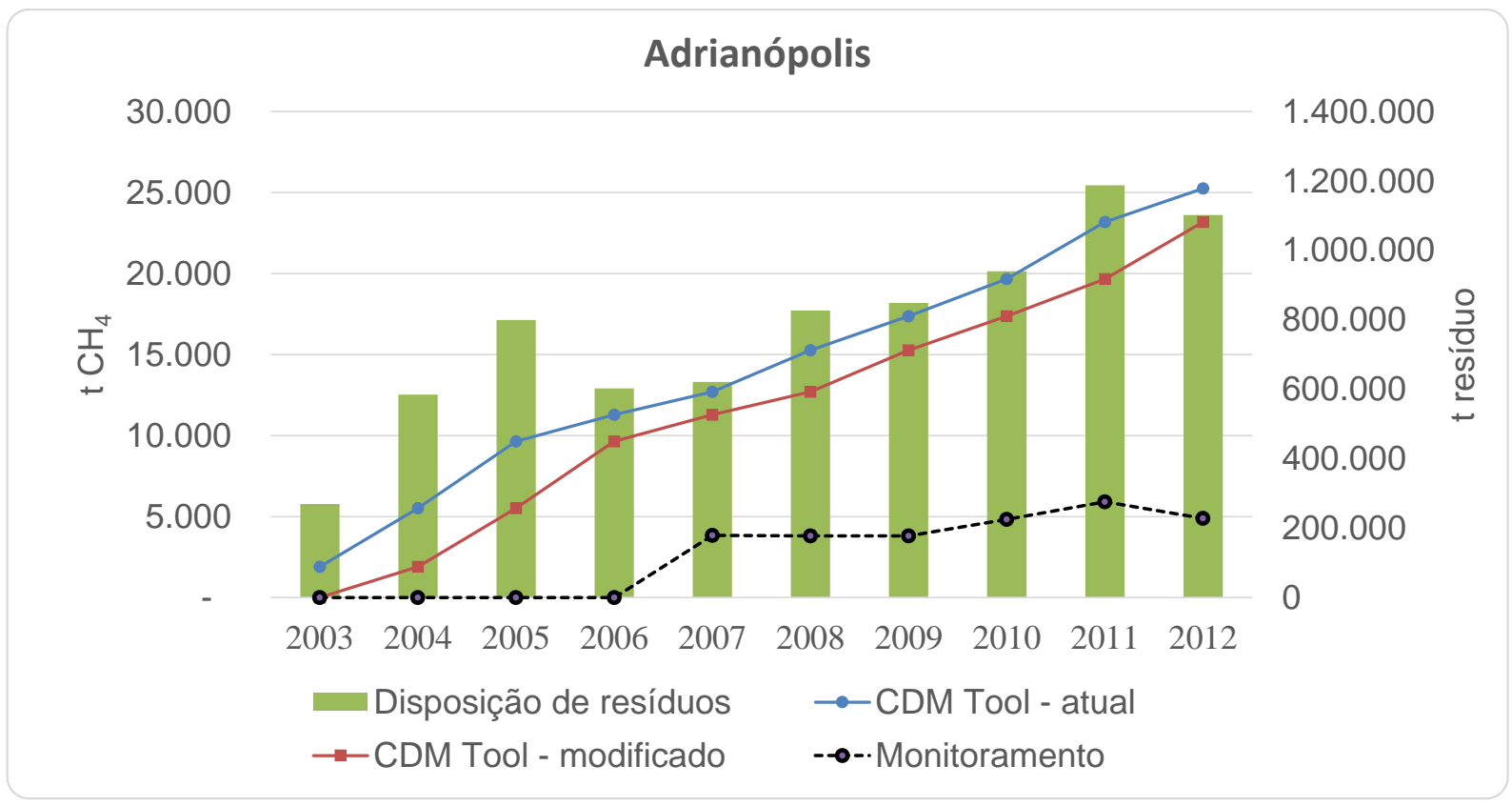

Figura 12 - Variação da geração de metano, apenas considerando-se a correção no CDM Tool, tendo em vista a disposição de resíduos, além do resultado do monitoramento Adrianópolis.

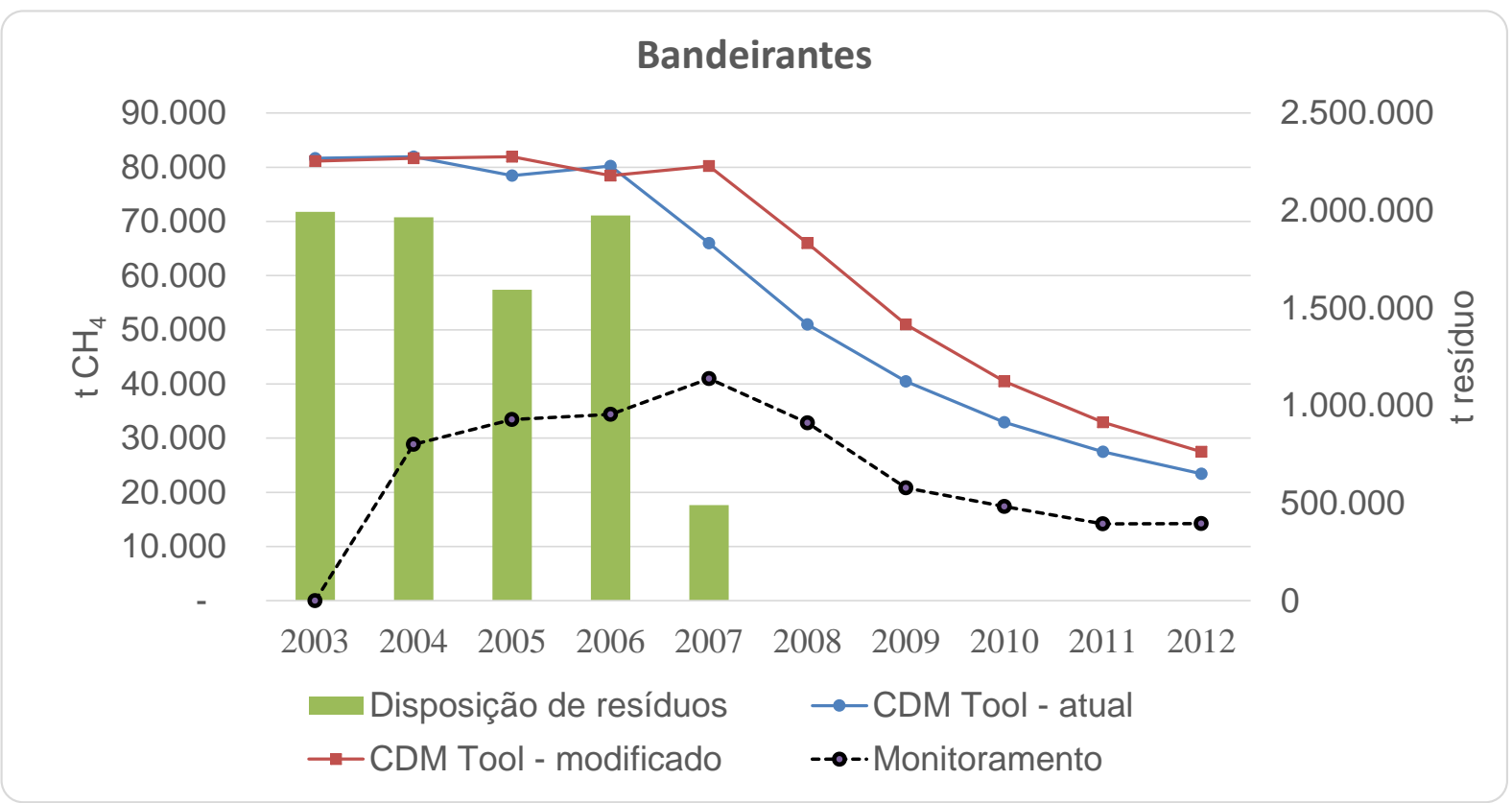

Figura 13 - Variação da geração de metano, apenas considerando-se a correção no CDM Tool, tendo em vista a disposição de resíduos, além do resultado do monitoramento Bandeirantes. 


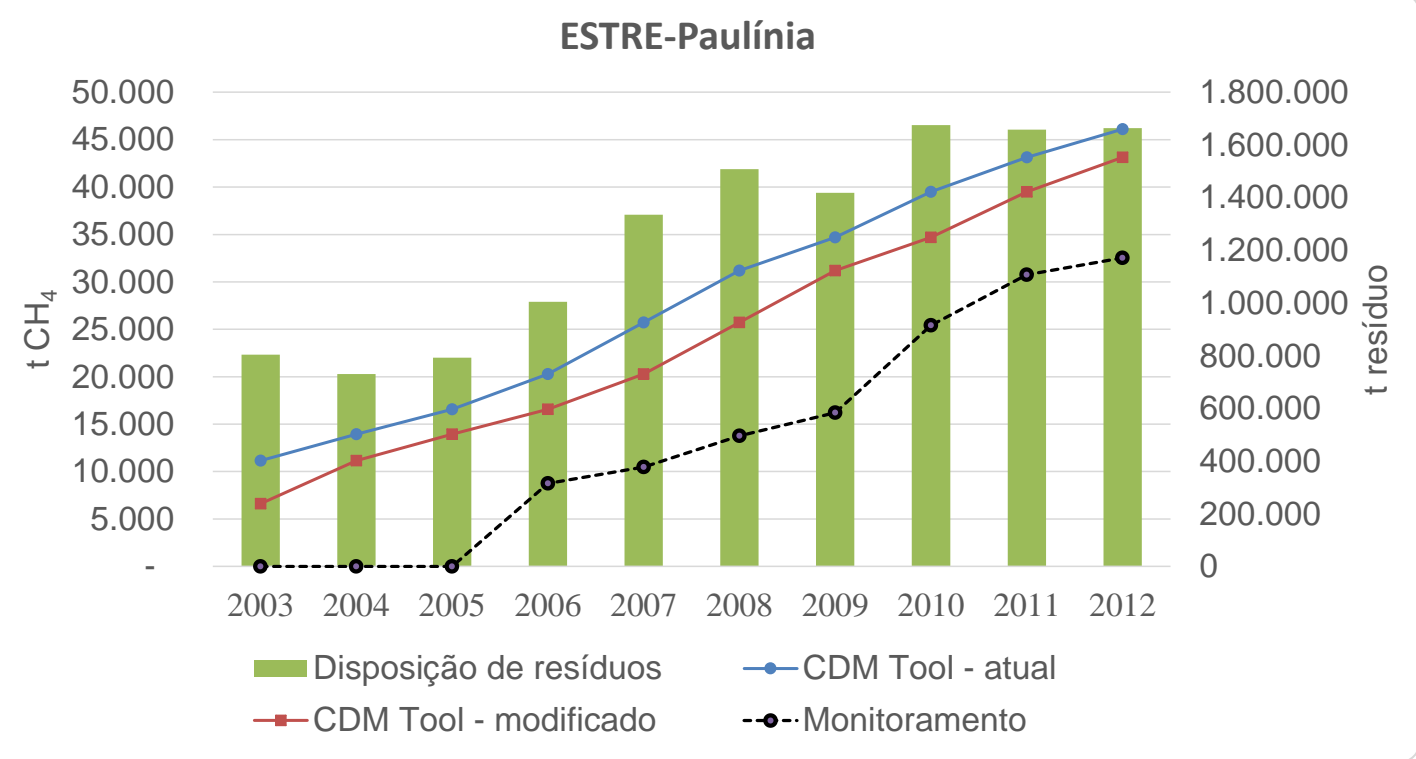

Figura 14 - Variação da geração de metano, apenas considerando-se a correção no CDM Tool, tendo em vista a disposição de resíduos, além do resultado do monitoramento ESTRE-Paulínia.

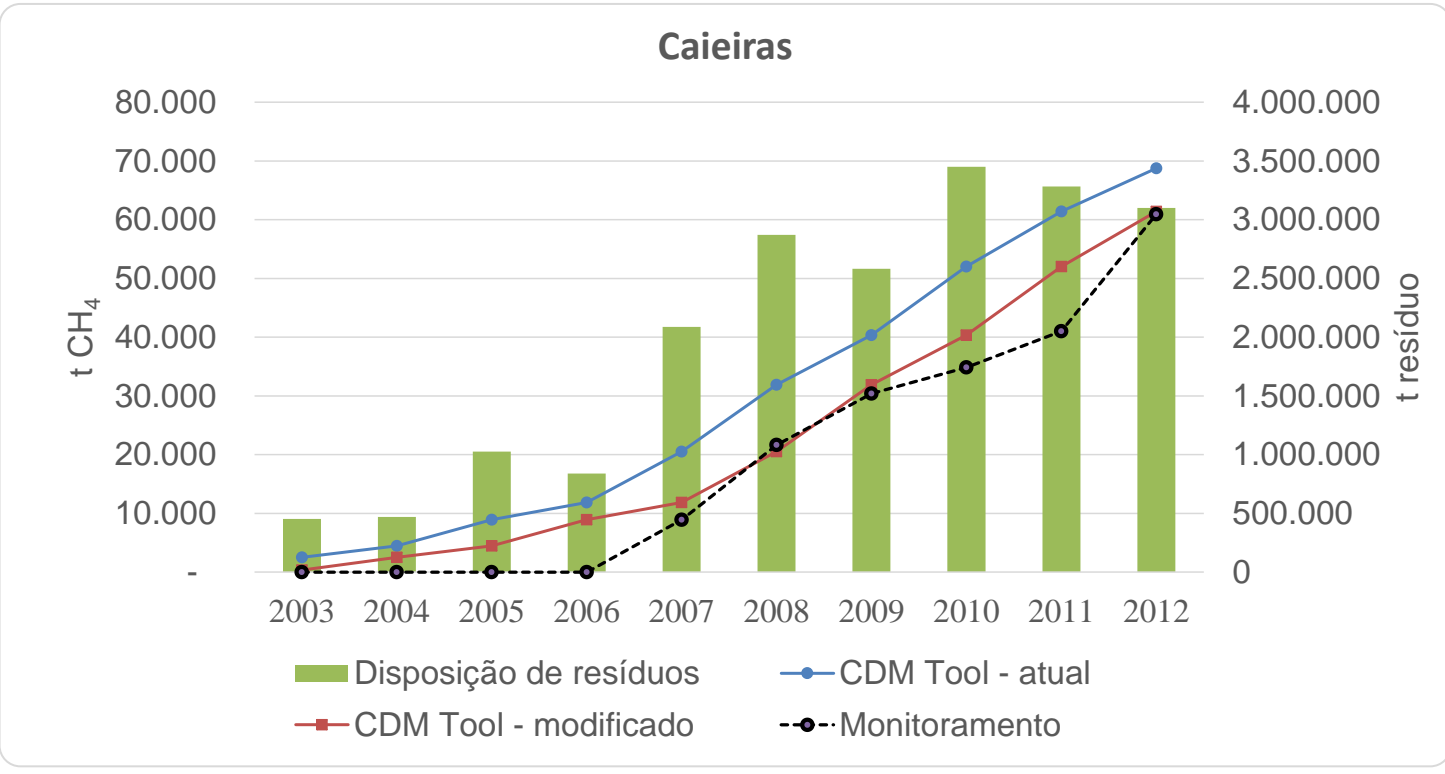

Figura 15 - Variação da geração de metano, apenas considerando-se a correção no CDM Tool, tendo em vista a disposição de resíduos, além do resultado do monitoramento Caieiras.

Quando se considera o fator de incerteza, como prescrito no CDM Tool, as estimativas de metano diminuem, aumentando as eficiências. Isso fica claro na observação das colunas E, F e G. Aparentemente, o fator $\varphi=0,75$ conduz a um desconto excessivo. 
Adrianópolis tem os resultados mais baixos, ainda mais baixos se comparados com a eficiência de recuperação prevista de $85 \%$. Esse valor será alterado para $40 \%$ no segundo $P D D$, o que é consistente com a afirmação de que uma zona em operação que não tenha cobertura superficial e esteja ligado a um sistema de recuperação de biogás tem um rendimento de extração de 35\% (Scharff e Jacobs, 2006). No entanto, talvez a principal razão para a baixa eficiência é que, de acordo com o $P D D$-2, o sistema de extração não estava cobrindo todas as áreas que recebiam resíduos.

É importante também notar na Tabela 18 que, para Adrianópolis, foi utilizada uma fração de metano no biogás de $39,74 \%$, conforme pode ser observado no $P D D$ 2 e com base em medições anteriores. Como o valor usual é de cerca de $50 \%$ (Themelis e Ulloa, 2007; IPCC, 2006), essa poderia ser uma indicação de que a pressão negativa para a extração estivesse sendo excessiva, levando a uma diluição do biogás com o ar exterior e diminuindo a proporção de $\mathrm{CH}_{4}$ para $\mathrm{CO}_{2}($ Bingemer e Crutzen, 1987). Scharff e Jacobs (2006) também indicam que o sistema de extração pode diminuir a concentração de metano e reduzi-lo do valor default de $55 \%$. Além disso, as diretrizes do IPCC (2006) indicam que a fração de metano no gás de aterro gerado não deve ser confundida com o metano medido no gás emitido a partir de $S W D S$, porque o $\mathrm{CO}_{2}$ - outro componente importante do biogás - é absorvido pela água do lixiviado, o que levaria a uma fração de metano superior. Se fosse usada a fração de $50 \%$, em vez de $39,74 \%$, os resultados de eficiência para Adrianópolis seriam ainda menores, em proporção inversa.

Por outro lado, Caieiras tem resultados muito elevados. Observe-se que, para esse projeto, foram adotadas as frações de resíduos default do IPCC (2006), diferentemente do Bandeirantes, um aterro sanitário vizinho, ambos servindo ao município de São Paulo. A fração relativa a alimentos - a que mais rápido degrada - é de $44,9 \%$ no primeiro caso e de $60,6 \%$ no segundo. Outra diferença é que Caieiras foi considerado estar em condições de clima temperado-úmido, mas para o Bandeirantes foi assumido estar em uma condição tropical-úmida. A razão disso é que os aterros estão em municípios diferentes, com temperaturas anuais médias ligeiramente diferentes, mas em lados opostos do limiar estabelecido pelo IPCC para a definição das constantes de decaimento. Se forem usados os mesmos parâmetros de Bandeirantes para Caieiras, sua eficiência máxima - considerando- 
se o CDM Tool com correções, mas sem fator de incerteza - cai de 106\% para 64\%, o que parece mais razoável.

A caracterização ambiental - temperatura média e umidade - é importante para o processo de geração de metano e pode ser aperfeiçoada, para refletir de fato as condições do local do aterro e não as condições da grande região onde ele se encontra. Além disso, as emissões de aterros - juntamente com a estabilização dos resíduos - podem ser melhoradas e aceleradas, de modo a ocorrerem consideravelmente mais rápido, como indicado por US-EPA (2005-b), se o aterro for concebido e operado como um biodigestor, envolvendo principalmente adição de umidade ou recirculação de lixiviado. US-EPA (2005-a) indica valores default para os parâmetros do modelo considerando aterros americanos convencionais (não em zonas áridas), uma constante de decaimento $k$ de 0,04 ano $^{-1}$ e um potencial de geração de metano $L_{0}$ de $100 \mathrm{~m}^{3} \mathrm{CH}_{4} / \mathrm{t}$ de resíduos, mas se forem operados como biodigestores os valores de $0,7 \mathrm{ano}^{-1}$ e $96 \mathrm{~m}^{3} \mathrm{CH}_{4} / \mathrm{t}$ de resíduos se aplicariam, respectivamente. Mesmo sabendo que o US-EPA (2005-b) sugere o valor conservativo para $k$ de 0,3 ano $^{-1}$ para aterros úmidos, isto ainda significa que se atinge um ritmo mais rápido de geração de gás com essa tecnologia.

No caso do Bandeirantes, as informações em seus relatórios de monitoramento enfatizam que a diferença entre a previsão e o resultado monitorado deveu-se principalmente à camada de cobertura final insuficiente, que aumentaria o escape de gás através da superfície do aterro. Este fato poderia explicar parcialmente a baixa eficiência de extração.

Na Tabela 19, os resultados deste trabalho são apresentados de outra forma: foram calculadas as diferenças percentuais entre as estimativas de geração de metano consideradas nos $P D D$ s e as calculadas com as correções nos modelos aqui indicadas, para cada um dos dois períodos de obtenção de crédito de sete anos. Para o primeiro período, os modelos utilizados nos $P D D$ s levaram a uma superestimação significativa na geração de metano, de $23 \%$ a $30 \%$, em três casos, Adrianópolis, ESTRE-Paulínia e Caieiras - os aterros recém-iniciados. Já para o segundo período de créditos, os modelos usados levam a uma subestimação em dois deles, Bandeirantes e ESTRE-Paulínia - os aterros encerrando as operações ou prestes a encerrá-las. 
Tabela 19 - Diferenças entre os modelos usados e os modelos sem os erros intrínsecos

\begin{tabular}{lcc}
\hline \multicolumn{1}{c}{ Aterro } & Primeiro período de créditos & Segundo período de créditos \\
& $P D D-1$ & $P D D-2$ \\
\hline Adrianópolis & $30 \%$ & $3 \%$ \\
Bandeirantes & $1 \%$ & $-13 \%$ \\
ESTRE-Paulínia & $23 \%$ & $-6 \%$ \\
Caieiras & $28 \%$ & $7 \%$ \\
\hline
\end{tabular}

Quando se considera um modelo de geração de biogás, existe uma outra fonte de incerteza, que é a própria quantidade de resíduos depositada anualmente. De 2003 a 2012, as diferenças anuais dos primeiros PDDs (que faziam previsão) para os segundos PDDs (que informavam o histórico) foram altas em três dos aterros. Em Adrianópolis, o aumento médio da quantidade de resíduos foi de 72\% (mínimo de 24\%, máximo de 168\%); Bandeirantes: aumento médio de 3\% (mínimo de 14\%, máximo 11\%); ESTRE-Paulínia: aumento médio de 106\% (mínimo de 22\%, máximo de 180\%); Caieiras aumento médio de 66\% (mínimo de 3\%, máximo de 136\%). No entanto, essas diferenças não afetaram a comparação entre os modelos feita neste trabalho, já que os valores de disposição de resíduos informados nos segundos $P D D s$ foram levados em conta nos modelos usados nos primeiros $P D D s$, eliminando-se, assim, esse tipo de incerteza. 


\section{Conclusões e sugestões}

Quando o Protocolo de Quioto entrou em vigor em 2005, ou mesmo antes, já que os empresários brasileiros estavam cientes de sua iminência, ele se tornou uma força propulsora para transformar lixões em aterros associados a captura e oxidação de metano. Isso ocorreu não só no Brasil, como também em outros países do mundo em desenvolvimento. Com o incentivo da obtenção de créditos de carbono, os empresários puderam fazer investimentos em projetos voltados para a solução dos problemas sanitários e ambientais e, quando os créditos fossem vendidos, a equação econômica seria concluída.

Nos últimos anos, além da queda vertiginosa nos preços dos créditos de carbono, os resultados demonstrados neste trabalho mostram que os projetos MDL enfrentam dificuldades na previsão de geração de metano. Embora parcialmente resolvidas com modelos melhorados e mais sofisticados, ainda há incertezas nesses modelos quanto ao estabelecimento dos valores para as constantes de decaimento e no potencial de geração de metano de cada tipo de resíduo.

As discrepâncias entre a previsão de geração e a captação efetiva de biogás dos aterros sanitários operados sob o MDL podem, em parte, ser explicadas pelo uso inadequado dos modelos de previsão. O próprio modelo corrente usado para prever a geração de metano nos projetos MDL tem erros intrínsecos, como demonstrado no decorrer deste trabalho. Os valores encontrados através deste modelo podem resultar em valores de geração de metano mais baixos ou mais altos, dependendo do período considerado. Situações limítrofes de temperatura e umidade, exemplificadas nos casos de Caieiras e Bandeirantes, bem como incertezas sobre a composição e quantidade dos resíduos e forma de operação do aterro, levam a variações importantes no resultado final obtido com o modelo. Nesse sentido, são necessárias pesquisas adicionais, a fim de aprofundar o olhar para a realidade local. Também falhas na estrutura de captação do biogás acabam influenciando negativamente a eficiência do projeto.

O presente estudo mostra a riqueza de informações que se pode obter do site da $U N F C C C / C D M$, em particular sobre os projetos MDL em andamento. Esse foi 
um dos objetivos intermediários propostos no início deste trabalho. Outros também foram atingidos, a partir do estudo desenvolvido:

- Foi obtido um critério para a análise dos projetos, pela seleção daqueles que tiveram um segundo período de créditos, permitindo eliminar a grande incerteza que é o volume de resíduos depositados;

- Foi feita a comparação da captação prevista, segundo o modelo original e outros possíveis, com a que aconteceu de fato;

- Confrontaram-se diversos modelos de geração e parâmetros.

Este trabalho serve também como fonte de inspiração para outras iniciativas no campo das energias renováveis e da mitigação das mudanças climáticas. Seria importante que este estudo fosse sucedido por um aprofundamento da pesquisa sobre as frações componentes dos resíduos depositados nos aterros sanitários brasileiros, as reais taxas de decaimento por tipo de resíduos, a influência das condições de temperatura e umidade, de modo a se fugir um pouco dos valores default do IPCC, mesmos os mais recentes (IPCC, 2006). Estudos sobre a influência da recirculação do lixiviado para aceleração da geração de metano poderiam indicar novos rumos para o tratamento de resíduos sólidos municipais, com ganhos ambientais. A necessidade de mais dados sobre o tema é primordial, embora não se possa esquecer a grande contribuição que o Protocolo de Quioto vem proporcionando na difusão de tecnologias ambientalmente saudáveis, secundado por uma grande quantidade de dados de excelente qualidade.

Este estudo também recomenda ao Conselho Executivo do MDL a correção de sua ferramenta metodológica para calcular as emissões dos locais de disposição de resíduos sólidos, já que sua utilização produz uma superestimação significativa na quantidade prevista de geração de metano em aterros sanitários novos e uma subestimação em aterros encerrando suas operações, mesmo com a utilização dos fatores recomendados pelo IPCC, sinalizando erradamente os investidores. Também há superestimação quando a ferramenta é usada para projetos que evitam biomassa de ser descartada em aterros e, já que não há medições do metano evitado, esse é um exemplo onde se põe em risco a integridade ambiental do Protocolo de Quioto, com uma geração de créditos de carbono indevida.

A legislação brasileira, agora com a Política Nacional de Resíduos Sólidos, tenta mais uma vez acabar com lixões, através da indicação dos aterros sanitários como destino final dos resíduos não aproveitados. Apesar de melhor solução 
sanitária, aterros têm maiores emissões de metano que os lixões, por terem ambiente anaeróbico. Nesse contexto, o uso de modelos melhorados para prever a geração de metano é fundamental, a fim de permitir a correta compreensão de como esse gás de efeito estufa pode ser usado como fonte de energia limpa em vez de ser liberado para a atmosfera, contribuindo para o aquecimento global. 


\section{Referências bibliográficas}

ALVES, J. W. S. e CARDOSO $\mathrm{F}^{\circ}$, E. Métodos de Estimativa de Geração e Recuperação Energética de metano nos Aterros. In: IX CBE - CONGRESSO BRASILEIRO DE ENERGIA, 2002, Rio de Janeiro. Anais do IX Congresso Brasileiro de Energia. 2002. p. 1760-1771.

BAHR, T. et al. Clean Development Mechanism - Tratamento de Resíduos Sólidos e Oxidação de Gás Metano para Minimização de Emissões. Technische Universität Braunschweig, Abt. Abfallwirtschaft, Beethovenstrasse 51a, 38106 Braunschweig, Alemanha, 2006. Disponível em http://www.webresol.org/textos/29-Fricke\%20K.pdf. Acesso em 06 jan. 2014.

BINGEMER, H. G. e CRUTZEN, P. J. The production of methane from solid wastes. Journal of Geophysical Research, Vol. 92, NO. D2: 2181-2187, 1987. 7p.

BRASIL. Lei No 6.938, de 31 ago. 1981, que institui a Política Nacional de Meio Ambiente. Brasília, 1981. Disponível em http://www.planalto.gov.br/ccivil_03/leis/16938.htm. Acesso em 16 jan. 2015.

Lei $\mathbf{N}^{\mathbf{0}}$ 9.605, de 12 fev. 1998, que institui a Lei de Crimes Ambientais. Brasília, 1988. Disponível http://www.planalto.gov.br/ccivil_03/leis/19605.htm. Acesso em 06 jan. 2014. Ministério da Ciência e Tecnologia. Primeiro Inventário Brasileiro de

Emissões Antrópicas de Gases de Efeito Estufa - Relatórios de Referência Emissões de Metano no Tratamento e na Disposição de Resíduos. Companhia de Tecnologia de Saneamento Ambiental CETESB. Brasília, 2002.

Lei $\mathbf{N}^{\mathbf{0}}$ 12.305, de 02 ago. 2010, que institui a Política Nacional de Resíduos Sólidos. Brasília, 2010. Disponível em http://www.planalto.gov.br/ ccivil_03/_ato2007-2010/2010/lei/112305.htm. Acesso em 06 jan. 2014.

Ministério do Meio Ambiente. Portaria MMA n ${ }^{\circ}$ 70/2014. Brasília, 2014. Disponível em http://www.mma.gov.br/governanca-ambiental/copaverde/nucleo-mudancas-climaticas/item/10076. Acesso em 01 jan. 2014. 
CASSINI, S. T.; BREDA M. Z.; NASCIMENTO T. B. Anexo B - Dedução da Fórmula do IPCC (2000) para Estimar as Emissões de $\mathrm{CH}_{4}$ pelos Resíduos Sólidos. In: CETESB (São Paulo) Emissões do setor de resíduos sólidos e efluentes líquidos, 1990 a 2008: relatório de referência / CETESB; Coordenação João Wagner Silva Alves, Josilene Ticianelli Vannuzini Ferrer; coordenação técnica Bruna Patrícia de Oliveira, Calvin Stefan Iost; equipe Rodrigo Cietto Ridolfi... [et al.]. São Paulo: CETESB, 2013. Página 138. Disponível em http://www.cetesb.sp.gov.br/userfiles/file/mudancasclimaticas/geesp/file/docs/pub licacao/inventario_estadual/sao_paulo/inventario_sp/relatorios_referencia/residuo s/primeiro_inventario_setor_residuos_web.pdf. Acesso em 01 jan. 2014.

CDM - Clean Development Mechanism. Informação sobre regras, metodologias, ferramentas e atividades de projeto estão disponíveis no endereço eletrônico: http://cdm.UNFCCC.int/. Acessos diversos, de 01 jan. 2014 a 31 mai. 2014.

\section{CHRISTENSEN, T. H. e KJELDSEN, P. Basic biochemical processes in}

landfills, Chapter 2.1 of Sanitary Landfilling: process, technology and environmental impact, Academic Press, Londres, 1989. ISBN 0-12-174255-5.

ICLEI. Manual para aproveitamento do biogás: Volume Um, Aterros Sanitários. ICLEI - Governos Locais pela Sustentabilidade, Secretariado para América Latina e Caribe, Escritório de projetos no Brasil, São Paulo, 2009.

IPCC. IPCC Second Assessment Report: Climate Change 1995 (SAR), 1995. Disponível em http://www.IPCC.ch/pdf/climate-changes-1995/IPCC-2ndassessment/2nd-assessment-en.pdf. Acesso em 06 jan. 2014.

Revised 1996 IPCC Guidelines for National Greenhouse Gas Inventories: Volumes 1, 2 and 3. Houghton, J.T., Meira Filho, L.G., Lim, B., Tréanton, K., Mamaty, I., Bonduki, Y., Griggs, D.J. and Callander, B.A. (Eds). Intergovernmental Panel on Climate Change (IPCC), IPCC/OECD/IEA. Paris, França, 1997.

Good Practice Guidance and Uncertainty Management in National Greenhouse Gas Inventories. Penman, J., Kruger, D., Galbally, I., Hiraishi, T., Nyenzi, B., Enmanuel, S., Buendia, L., Hoppaus, R., Martinsen, T., Meijer, J., Miwa, K. and Tanabe, K. (Eds). Intergovernmental Panel on Climate Change (IPCC), IPCC/OECD/IEA/IGES. Hayama, Japão, 2000. 
Summary for Policymakers and Technical Summary of Climate

Change 2001: Mitigation. Contribution of Working Group III to the Third Assessment Report of the Intergovernmental Panel on Climate Change, Bert Metz et al. eds. Cambridge University Press. Cambridge, Reino Unido, 2001.

2006 IPCC Guidelines for National Greenhouse Gas Inventories,

Prepared by the National Greenhouse Gas Inventories Programme, Eggleston H.S., Buendia L., Miwa K., Ngara T. and Tanabe K. (eds). Publicação: IGES, Japão, 2006.

KYOTO PROTOCOL. Versão original em inglês, 1997. Disponível em http://UNFCCC.int/resource/docs/convkp/kpeng.pdf. Acesso em 01 jan. 2014.

OONK, H. Literature Review: Methane from Landfills - Methods to Quantify Generation, Oxidation and Emission, Oonkay! Innovations in Environmental Technology, Holanda, abril 2010.

Publicação eletrônica [Comunicação pessoal]. Mensagem recebida por <mauro.meirelles.mct@gmail.com> em 16 out. 2014.

PROTOCOLO DE QUIOTO. Versão em português, 1997. Disponível em: http://www.mct.gov.br/upd_blob/0012/12425.pdf e acessado em 06 jan. 2014.

SCHARFF, H. e JACOBS, J., 2006. Applying guidance for methane emission estimation for landfills. Waste Management 26 (2006): 417-429. 13 p.

TEIXEIRA, P. F; LIOTTI, R. G.; TORVES, J. C.; FINOTTI, A. R.; CABRAL, A.; VAZOLLER, R. F.; TEIXEIRA, C. E.; MARINHO, F.A.M., Processo de oxidação do metano através das bactérias metanotróficas em coberturas de aterros sanitários. VI Simpósio Brasileiro de Solos Não Saturados - Salvador - 2007. Disponível em $\quad$ http://www.cetesb.sp.gov.br/userfiles /file/mudancasclimaticas/biogas/file/docs/artigos_dissertacoes/teixeira_processo_ oxidacao_2007.pdf. Acesso em 06 jan. 2014.

THEMELIS, N. J., ULLOA, P. A. Methane generation in landfills. Earth Engineering Center and Department of Earth and Environmental Engineering, Columbia University, New York, NY 10027, USA. Renewable Energy 32: 12431257, 2007. 15p.

UNFCCC. COP Decision 17/CP.8 - Annex, paragraph 11, 2002a. Disponível em 
http://unfccc.int/resource/docs/cop8/07a02.pdf\#page=2. Acesso em 06 jan. 2014. COP Decision 18/CP.8 - Annex, paragraphs 9 and 10, 2002b. Decisão disponível em: http://unfccc.int/resource/docs/cop8/07a02.pdf\#page=13; anexo em: http://unfccc.int/resource/docs/cop8/08.pdf. Acesso em 06 jan. 2014.

Methodological Tool - Emissions from solid waste disposal sites (Version 06.0.1), 2011. Disponível em http://cdm.UNFCCC.int/methodologies/PAmethodologies/tools/am-tool-04v6.0.1.pdf. Acesso em 06 jan. 2014.

COP Decision 24/CP.19 - Annex I, paragraphs 3, 9, and 10, 2013. Disponível em: http://unfccc.int/resource/docs/2013/cop19/eng/10a03.pdf\#page=2. Acesso em 06 jan. 2014.

US-EPA. Landfill Gas Emissions Model (LandGEM) Version 3.02 User's Guide. EPA-600/R-05/047. Estados Unidos, 2005a.

First-Order Kinetic Gas Generation Model: Parameters for Wet Landfills. EPA-600/R-05/072. Estados Unidos, 2005b.

VAN ELK, A. G. H. P. Redução de emissões na disposição final. Coordenação Karin Segala - Rio de Janeiro: IBAM. Brasil, 2007.

VON RANDOW, L. E. et al. Mecanismo de Desenvolvimento Limpo e o Setor do Lixo: Oportunidades Geradas no Brasil. Revista Jovens Pesquisadores. Ano V, N. 8, jan/jul 2008. Disponível em http://www.mackenzie.br/dhtm/seer/index.php/jovenspesquisadores/article/downl oad/923/430. Acesso em 16 jan. 2015.

WORLD BANK - Energy Sector Management Assistance Programme, Handbook for the Preparation of Landfill Gas to Energy Projects in Latin America and the Caribbean. Preparado por Conestoga-Rovers \& Associates. Ref. No. 019399 (6). Canadá, 2004. 